\title{
A novel mitragynine analog with low efficacy mu-opioid receptor agonism displays antinociception with attenuated adverse effects
}

Soumen Chakraborty ${ }^{\mathrm{a}, \mathrm{b}}$, Jeffrey F. DiBerto ${ }^{\mathrm{c}}$, Abdelfattah Faouzi ${ }^{\mathrm{a}, \mathrm{b}}$, Sarah M. Bernhard ${ }^{\mathrm{a}, \mathrm{b}}$, Anna M. Gutridge $^{\mathrm{d}}$, Steven Ramsey ${ }^{\mathrm{e}}$, Yuchen Zhou ${ }^{\mathrm{e}}$, Davide Provasi ${ }^{\mathrm{e}}$, Nitin Nuthikattu ${ }^{\mathrm{a}, \mathrm{b}}$, Rahul Jilakara ${ }^{\mathrm{a}, \mathrm{b}}$, Melissa N.F. Nelson ${ }^{\mathrm{f}}$, Wesley B. Asher ${ }^{\mathrm{f}}$, Shainnel O. Eans ${ }^{\mathrm{g}}$, Lisa L. Wilson ${ }^{\mathrm{g}}$, Satyanarayana M Chintala $^{\mathrm{b}}$, Marta Filizola ${ }^{\mathrm{e}}$, Richard M. van Rijn ${ }^{\mathrm{d}}$, Elyssa B. Margolis ${ }^{\mathrm{h}}$, Bryan L. Roth ${ }^{\mathrm{c}}$, Jay P. McLaughlin $^{\mathrm{g}}$, Tao Che ${ }^{\mathrm{a}, \mathrm{b}, \mathrm{c}}$, Dalibor Sames ${ }^{\mathrm{i}}$, Jonathan A. Javitch ${ }^{\mathrm{f}^{*}}$, and Susruta Majumdar ${ }^{\mathrm{a}, \mathrm{b},{ }^{*}}$

${ }^{a}$ Center for Clinical Pharmacology, University of Health Sciences \& Pharmacy at St. Louis and Washington University School of Medicine, St. Louis, MO 63110, USA.

bepartment of Anesthesiology, Washington University School of Medicine, St Louis, MO 63110, USA. 'Department of Pharmacology, University of North Carolina at Chapel Hill School of Medicine, Chapel Hill, NC 27599, USA.

${ }^{\mathrm{d} D e p a r t m e n t}$ of Medicinal Chemistry and Molecular Pharmacology, College of Pharmacy, Purdue University, West Lafayette, IA 47907, USA

eDepartment of Pharmacological Sciences, Icahn School of Medicine at Mount Sinai, New York, NY 10029, USA.

${ }^{\mathrm{f}}$ Departments of Psychiatry and Molecular Pharmacology and Therapeutics, Columbia University Vagelos College of Physicians and Surgeons, and Division of Molecular Therapeutics, New York State Psychiatric Institute, New York, NY 10032, USA.

'Department of Pharmacodynamics, University of Florida, Gainesville, FL 032610, USA.

hDepartment of Neurology, UCSF Weill Institute for Neurosciences, University of California San Francisco, San Francisco, California 94158, USA.

iDepartment of Chemistry, Columbia University, NY 10027, USA.

\section{$\underline{\text { Corresponding author(s) }}$}

Jonathan A. Javitch, MD PhD

Email: jaj2@cumc.columbia.edu

Tel No: 914-484-8668

and

Susruta Majumdar, $\mathrm{PhD}$

Email:susrutam@email.wustl.edu

Tel no: 314-446-8162 
Keywords: Opioids, mitragynine, buprenorphine, kratom, partial mu opioid agonism.

\section{ABSTRACT}

Dried kratom leaves are anecdotally used for the treatment of pain, opioid dependence, and alcohol use disorder. We have previously shown that kratom's natural products (mitragynine) and semi-synthetic analogs (7-hydroxy mitragynine $(7 \mathrm{OH})$ and mitragynine pseudoindoxyl) are mu opioid receptor (MOR) agonists that show minimal $\beta$-arrestin2 recruitment. To further investigate the structure activity relationships of G-protein potency, efficacy, and $\beta$-arrestin2 recruitment, we diversified the mitragynine/7OH templates at the $\mathrm{C} 9,-10$ and -12 positions of the aromatic ring of the indole moiety. Three lead C9 analogs, synthesized by swapping the 9-methoxy group with varied substituents, namely phenyl (SC11), methyl (SC12), 3'-furanyl (SC13), were further characterized using a panel of in vitro and ex vivo electrophysiology assays. All three compounds were partial agonists with lower efficacy than both DAMGO and morphine in heterologous Gprotein assays and synaptic physiology. SC11-13 also showed lower recruitment of both $\beta$-arrestin subtypes compared to DAMGO, and in assays with limited MOR receptor reserve, the G-protein efficacy of SC11, SC12 and SC13 was comparable to buprenorphine. In mouse models, at equianalgesic doses SC13 showed MOR-dependent analgesia with potency similar to morphine without respiratory depression, hyperlocomotion, constipation, or place conditioning. Taken together, these results suggest that MOR agonists with a G-protein efficacy profile similar to buprenorphine can be developed into opioids that are effective analgesics with greatly reduced liabilities. 


\section{INTRODUCTION}

Opioids targeting the mu opioid receptor (MOR) are used for the treatment of moderate to severe pain. ${ }^{1}$ However, MOR activation is also associated with serious side effects such as tolerance, physical dependence, and risk of abuse ${ }^{1-3}$ opioid-induced respiratory depression can be lethal at high doses and constipation can be debilitating as well. Opioid abuse and overdose are one of the leading causes of accidental death in the United States, responsible for more than 47,000 deaths in 2019 alone. $^{4}$ Therefore, discovery of a new class of MOR agonist molecular scaffold that retains potent analgesic actions but with reduced side effects and abuse potential is a pressing challenge for the scientific community.

Applying molecular modeling based on active state MOR structures, synthesis of novel ligands and using newer assays with limited receptor reserve, the opioid field is revisiting the strategy of developing low efficacy partial agonists as novel safer analgesics. ${ }^{5-7}$ Numerous MOR partial agonists with multifunctional activity at other opioid receptor subtypes have been described in the literature, such as buprenorphine, nalbuphine and pentazocine, validating the feasibility of this strategy. The identification of novel partial agonists may have been hindered by modern screening assays that assess G-protein activity, yet have large receptor reserve (so called "spare" receptors), which prevents a simple delineation of lower efficacy compounds. ${ }^{8,9}$ In order to develop candidate pain relievers based on mitragynine and $7 \mathrm{OH}$ scaffolds with a particular goal of assessing G-protein efficacy and its impact on opioid function in vivo, we aimed at diversification of the mitragynine template and evaluated the resulting compounds in systems capable of detecting their true efficacy. 
The psychoactive plant Mitragyna speciosa, commonly known as kratom, has traditionally been used for the treatment of opioid dependence. ${ }^{10}$ The dry leaves of kratom are used in traditional medicine as an analgesic treatment and are typically consumed directly or brewed as tea. The major active alkaloid found in kratom is mitragynine, along with more than 40 other minor alkaloids. ${ }^{11-}$ ${ }^{16}$ In recent years, we have become interested in the chemistry and pharmacology of kratom alkaloids as probes to understand opioid receptor function. ${ }^{11,17-23}$ Previous reports from our group reported that mitragynine (possessing an indole core), its oxidation product $7 \mathrm{OH}$ (possessing an indolenine core), and mitragynine pseudoindoxyl (MP, a skeletal rearrangement product of 7OH with a spiro-pseudoindoxyl core) (Figure 1A), are all opioid antinociceptive agents ${ }^{18,19}$ and Gprotein biased MOR agonists. ${ }^{17,18,20,22}$ We also reported oxidative metabolism of mitragynine to 7OH mitragynine using a CYP3A-mediated pathway following oral administration of mitragynine in mice. ${ }^{19}$ Metabolism of mitragynine to $7 \mathrm{OH}$ in vitro ${ }^{24}$ and in $\operatorname{dog} s^{25}$ has been reported by other groups too. More recently, we also reported an atomic-level description of how kratom alkaloids may bind and allosterically modulate $\mathrm{MOR}^{21}$. In vivo studies in mice revealed that kratom and a number of its alkaloids are analgesic ${ }^{16,18,19,26-28}$ ameliorate opioid physical dependence, ${ }^{23,26}$ decrease alcohol intake ${ }^{22}$, and inhibit self-administration of heroin in rats. ${ }^{29}$ While $7 \mathrm{OH}$ retains its abuse potential after both intravenous and parental administration ${ }^{22}$, intravenous mitragynine is not self-administered, ${ }^{29,30}$ suggesting that it may be possible to design a safer analgesic based on this template by further optimization of the mitragynine template.

Chemistry studies to date are limited in the structure-activity relationship (SAR) investigations of both mitragynine and $7 \mathrm{OH}$ scaffolds, prompting the present development of diversification strategies across these two indole-based templates. Here, we report the pharmacological characterization of mitragynine and $7 \mathrm{OH}$ mitragynine analogs synthesized by 
introducing a phenyl, 3'-furanyl, and methyl group at the C9/10/12 positions of the aromatic ring in the two templates. The lead compounds SC11, SC12 and SC13 (Figure 1A) showed lower Gprotein efficacy at MOR than DAMGO and morphine in in vitro assays with limited receptor reserve and ex vivo assays as well. The most potent and selective Gi-1 MOR agonist among the three leads, SC13, displayed antinociceptive activity comparable to morphine but exhibited greatly attenuated constipation, respiratory depression, and locomotor activity. Furthermore, SC13 displayed no reinforcement behavior in a conditioned-place preference assay. Taken together, the reported in vitro assays in cells, ex vivo assays in rat brain slices, and in vivo experiments in mouse suggest that the partial agonist SC13 exerts effective MOR-mediated analgesia with a side effect profile far superior to clinically used MOR-based antinociceptive agents.

\section{RESULTS}

\section{Chemistry:}

To assess the pharmacological profile of mitragynine and 7OH templates, structure activity relationships (SAR) studies were carried out by modifying three different regions of the aromatic indole ring on both scaffolds, namely the $\mathrm{C} 9, \mathrm{C} 10$, and $\mathrm{C} 12$ positions, with phenyl, 3 'furanyl and methyl group substitutions. (Figure 1). The unsaturated acrylate segment of both templates is thought to be an essential component for the efficient binding of any mitragynine- or 7OH-related analog into the orthosteric MOR binding pocket. ${ }^{17}$ Therefore, this feature of both scaffolds was kept constant throughout our studies. We synthesized a total of 18 analogs and investigated their pharmacology with in vitro assays.

Synthesis of analogs was initiated from mitragynine (1) extracted from dry kratom powder following a modified protocol reported by Varadi et al. ${ }^{18}$ To gain access to the C9 position on the 
mitragynine scaffold, 1 was converted to triflate (4, Figure 1B). This intermediate triflate was converted to SC1, SC3, and SC4 using palladium-catalyzed coupling reactions. Then SC1, SC3, and SC4 were transformed to their corresponding 7OH derivatives SC13, SC11, and SC12, respectively, using oxone ${ }^{\circledR}$ and aqueous $\mathrm{NaHCO}_{3}$. Functionalization of the $\mathrm{C} 10$ position on the mitragynine scaffold was achieved by selectively incorporating bromine at the $\mathrm{C} 10$ position using a protocol developed by Takayama. ${ }^{31}$ Mitragynine (1) was first converted to 10-bromo mitragynine 6 using a 3-step reaction sequence (Figure 1C). 10-bromo mitragynine 6 was then subjected to different coupling reactions to obtain C10 mitragynine analogs, namely SC21, SC22, and SC23. SC21-23 were then treated with oxone ${ }^{\circledR}$ and aqueous $\mathrm{NaHCO}_{3}$ to obtain the corresponding $7 \mathrm{OH}$ derivatives SC31-33, respectively. For the C12 derivatives, as shown in Figure 1D, mitragynine (1) was brominated directly to afford mainly 12-bromo mitragynine (7). The same reaction sequence (as in C10) was followed to synthesize C12 substituted analogs SC71-73. Next, all were treated with oxone ${ }^{\circledR}$ and aqueous $\mathrm{NaHCO}_{3}$ to yield $\mathrm{C} 127 \mathrm{OH}$ derivatives SC81-83. Detailed synthetic procedures and characterization data for each of the compounds are shown in the methods section.

\section{SAR and in vitro functional screening of synthesized analogs}

Each synthesized compound was first evaluated for G-protein activity using the high throughput Glo-sensor cAMP inhibition assay and Tango $\beta$-arrestin2 recruitment assay. For cAMP assays, HEK-T cell lines transiently expressing human MOR, KOR and DOR were used, while for Tango assays, HTLA cells transiently expressing TEV fused $\beta$-arrestin 2 were used. The data were normalized to that of prototypical full agonists, DAMGO for MOR, U50,488H for KOR, and DPDPE for DOR, respectively. cAMP and $\beta$-arrestin2 data for MOR are presented in Table 1 with 
representative SAR of selected compounds shown in Appendix 1-Figure 1A-B. Additionally, results for KOR and DOR are summarized in Appendix 1-Table 1 and Appendix 1-Table 2.

We initiated our investigations with modification at the C9 position of mitragynine with the syntheses of SC1 (9-3'-furanyl mitragynine), SC3 (9-phenyl mitragynine), and SC4 (9-methyl mitragynine), each of which revealed moderate activity and potency $\left(\mathrm{EC}_{50}>50 \mathrm{nM}\right)$ in $\mathrm{cAMP}$ assays and poor $\beta$-arrestin2 recruitment $\left(\mathrm{E}_{\max }<20 \%\right)$ at MOR. We then investigated three other C9 analogs on the 7OH template, 9-3'-furanyl 7OH (SC13), 9-phenyl-7OH (SC11) and 9-methyl7OH (SC12). We specifically picked these moieties in order to explore the effect of an aryl(phenyl), a heteroaryl-(3'-furanyl) and an aliphatic group such as methyl on this template. Incorporation of a phenyl ring at the $\mathrm{C} 9$ end of the $7 \mathrm{OH}$ scaffold led to an increased cAMP potency at $\mathrm{MOR}\left(\mathrm{EC}_{50}=36.2 \mathrm{nM}\right.$, Table 1 and Appendix 1-Figure 1A) in comparison with the same substituent on the mitragynine template $\left(\mathrm{EC}_{50}=83.2 \mathrm{nM}, \mathbf{S C 3}\right.$, Table 1). Introduction of an aliphatic methyl group at C9 of the 7OH scaffold in $\mathbf{S C 1 2}$ improved potency in the cAMP assay with $\mathrm{MOR}\left(\mathrm{EC}_{50}=5.3 \mathrm{nM}\right)$ compared to the 9-methyl mitragynine $\mathbf{S C 4}\left(\mathrm{EC}_{50}=82.9 \mathrm{nM}\right)$. Furthermore, grafting of a 3'-furanyl group at $\mathrm{C} 9$ of $7 \mathrm{OH}(\mathbf{S C 1 3})$ showed similar potency $\left(\mathrm{EC}_{50}=\right.$ $7.3 \mathrm{nM})$ in the cAMP assay to that of $\mathbf{S C 1 2}$ as well as the parent $7 \mathrm{OH}$ mitragynine $\left(\mathrm{EC}_{50}=5.9\right.$ $\mathrm{nM})$. Interestingly, while the corresponding analogs on the mitragynine template (SC1, 3 \& 4) showed poor $\beta$-arrestin2 recruitment, the analogs on the $7 \mathrm{OH}$ template (SC11 and 12) showed robust arrestin recruitment in Tango assays at MOR relative to DAMGO: $\mathbf{S C 1 3}$ showed 45\% $\beta$ arrestin2 efficacy relative to DAMGO, but higher than the parent template $7 \mathrm{OH}$ (Table 1 and Appendix 1-Figure 1B). The potencies of SC11, SC12 and SC13 for recruiting arrestin however remained poor (with $\mathrm{EC}_{50}>10 \mu \mathrm{M}$ for each). SC11-13 showed no $\beta$-arrestin2 recruitment at $\mathrm{KOR}$, but $\beta$-arrestin2 recruitment was seen at DOR $\left(E_{\max }>100 \%\right)$ with all three analogs (Appendix 1- 
Table 1 and Appendix 1-Table 2). In cAMP assays, SC13 was most selective for MOR over DOR and KOR, showing 30-fold and 14-fold selectivity compared to SC12 and SC11, which were less MOR selective. (Table 1, Appendix 1-Table 1, and Appendix 1-Table 2).

The next set of analogs were designed at the C10 and C12 ends of both the mitragynine and $7 \mathrm{OH}$ templates. None of the synthesized analogs at $\mathrm{C} 10$ and $\mathrm{C} 12$ exhibited promising activities at MOR in the cAMP assay except for 12-methyl 7OH $(\mathbf{S C 8 3})$, with an $\mathrm{EC}_{50}=11.2 \mathrm{nM}$. Notably, these analogs also did not effectively recruit $\beta$-arrestin2 $\left(\mathrm{E}_{\max }<20 \%\right)$ in the Tango assay (Table 1).

Our mitragynine template diversification attempts did produce numerous partial agonists, but with the exception of SC83, their potency was greater than $50 \mathrm{nM}$, in the cAMP assay. Therefore, SC11, SC12 and SC13 (all C9 substituted 7OH analogs) were chosen as leads from the series of compounds synthesized. SC11-13 were evaluated in the PathHunter assay, ${ }^{18,22}$ which we and others $^{12}$ have previously used to measure $\beta$-arrestin 2 activity of the parent natural products. In this assay, like morphine $\left(\mathrm{E}_{\max }=31 \%\right), \mathbf{S C 1 1 - 1 3}$ were found to recruit $\beta$-arrestin2 with greatly reduced efficacy $\left(\mathrm{E}_{\max }<20 \%\right)$ compared to DAMGO (Appendix 1-Figure 1C). These observations suggest that the much higher $\beta$-arrestin2 recruitment seen in the Tango assay is likely a consequence of higher amplification of arrestin signaling compared to the PathHunter assay. In hMOR (human MOR) competition binding assays using ${ }^{3} \mathrm{H}-\mathrm{DAMGO}$ as the radioligand, DAMGO and morphine showed subnanomolar affinity for MOR; among the lead analogs SC13 had the highest affinity $\left(\mathrm{K}_{\mathrm{i}}=6 \mathrm{nM}\right)$ and SC11 and SC12 had high (15-17 nM) affinity at MOR as well (Appendix 1Figure 1D).

\section{SC11-13 are MOR partial agonists in BRET-based G-protein activation assays}


We next assessed SC11-13 and the controls DAMGO, morphine, buprenorphine, and fentanyl for G-protein activation (Gi-1) using TRUPATH assays and arrestin recruitment ( $\beta$-arrestin1/2) using another BRET-based assay, which produce less signal amplification compared to the cAMP and Tango assays. ${ }^{32}$

SC11-13 showed MOR partial agonist activity with $E_{\max }=60-70 \%$ of DAMGO at Gi-1. Fentanyl showed higher efficacy $\left(\mathrm{E}_{\max }=122 \%\right)$ and morphine showed an efficacy only slightly lower than DAMGO ( $\left.\mathrm{E}_{\max }=94 \%\right)$, whereas buprenorphine had an $\mathrm{E}_{\max }=44 \%$ in this assay (Figure 2A and Appendix 1-Table 3). Thus, the intrinsic efficacy of SC11-13 appeared somewhat higher than for the prototypic MOR partial agonist buprenorphine, but lower than DAMGO, fentanyl and morphine under these conditions (Appendix 1-Figure 1E and Appendix 1-Table 3).

The novel compounds and MOR controls were also characterized using the TRUPATH assay $^{32}$ for activation of other G $\alpha$-i/o subtypes (Gi-2, Gi-3, GoA, GoB and Gz). SC11, SC 12, and SC13 were found to be partial agonists at all these G-protein subtypes and showed an efficacy profile similar to buprenorphine at the same subtypes (Figure 2H and Appendix 1-Table 4). The highest potencies (Figure 2G and Appendix 1-Table 4) and efficacy (Figure 2H and Appendix 1-Table 4) were seen at Gz for SC11-13 as well as the MOR reference compounds. Specifically, the Gz efficacy for SC11-13 was similar to both buprenorphine and morphine, but lower than DAMGO and fentanyl. Notably, the higher efficacy and equipotency at Gi-1 and Gz for buprenorphine relative to DAMGO and higher potency of morphine at Gz relative to Gi-1, are consistent with recent work from the Bidlack group. ${ }^{33}$

In $\beta$-arrestin2 recruitment assays, DAMGO ( $\left.\mathrm{E}_{\max }=100 \%\right)$ and fentanyl $\left(\mathrm{E}_{\max }=98 \%\right)$ robustly recruited $\beta$-arrestin2 (Figure 2B and Appendix 1-Table 3), whereas morphine was moderately active $\left(\mathrm{E}_{\max }=32 \%\right)$. and buprenorphine was less active ( $\left.\mathrm{E}_{\max }<10 \%\right)$ (Appendix 1- 
Figure 1F and Appendix 1-Table 3). $\beta$-arrestin2 recruitment induced by incubation with buprenorphine and SC11-13 was not measurable with this assay (Appendix 1-Figure 1F and Appendix 1-Table 3). In this assay, SC11, SC12, SC13, morphine, and buprenorphine failed to show recruitment of $\beta$-arrestin1, whereas fentanyl displayed $83 \%$ efficacy in this assay compared to DAMGO. In summary, in the BRET-based assays, SC11-13 acted as MOR partial agonists for $\mathrm{G}$ protein activation but not show arrestin recruitment.

We also evaluated MOR selectivity of SC13 (our behavioral lead-see next section) versus KOR/DOR selectivity for Gi-1 activation. SC13 was found to have $\sim 100$-fold lower potency at DOR and KOR (Appendix 1-Figure 1G-H) in this assay.

Recent work have shown that nanobodies (Nb33 and Nb39) can be used as receptoractivation sensors to accurately probe agonist activity. ${ }^{34,35}$ Canals and co-workers have recently used a conformationally selective Nb33-recruitment assay $^{20}$ to more accurately determine efficacy $^{5}$ of MOR ligands in an unamplified manner more akin to the BRET-based direct arrestin recruitment assay. Since morphine was a partial agonist in this assay ( $E_{\max }=71 \%$ ), compared to 94\% in our Gi-1 assays, we used this assay to determine the efficacy of SC11-13 and compared it to DAMGO, morphine and buprenorphine in HEK293-T cells transiently transfected with the human and murine-MOR. In this assay, the efficacies of morphine and buprenorphine were $72 \%$ and 24\% respectively compared to DAMGO, and SC11, 12 and $\mathbf{1 3}$ each showed efficacies of $\sim 20 \%$ in this assay at hMOR (Figure 2C/ Appendix 1-Figure 1I and Appendix 1-Table 3). Similarly at murine MOR (Figure 2D/ Appendix 1-Figure 1J and Appendix 1-Table 3) the efficacies of SC11-12 $\left(\mathrm{E}_{\max }=15-18 \%\right)$ and SC13 (8\%) were more comparable to buprenorphine (20\%) and lower than morphine $(69 \%)$. Thus, the efficacies of our lead ligands are similar to buprenorphine and far lower than morphine in this assay, and the efficacies of our control drugs 
matched published reports. ${ }^{5}$ While it is difficult to accurately determine potencies of our leads with such limited dynamic range, the potency of $\mathbf{S C 1 3}$ (our behavioral lead) was in the same range as morphine as well as DAMGO (Figure 2C/D).

\section{SC11-13 showed low efficacies for inhibition of synaptic transmission}

To gauge partial agonism in a physiologically natural, endogenous system, we utilized whole cell electrophysiological recordings from ventral tegmental area (VTA) neurons in acute rat brain slices. Full MOR agonists such as DAMGO strongly inhibit GABA release onto VTA neurons (Figure 2E). ${ }^{36}$ Thus, we tested the efficacy of $10 \mu \mathrm{M} \mathrm{SC11,} \mathrm{SC12,} \mathrm{and} \mathrm{SC13} \mathrm{at} \mathrm{this}$ synapse by measuring electrically-evoked $\mathrm{GABA}_{\mathrm{A}}$ receptor-mediated IPSCs. As a control, in brain slices from the same rats, we also measured responses to a saturating concentration of DAMGO $(5 \mu \mathrm{M})$, and $10 \mu \mathrm{M}$ morphine. The mean inhibition of evoked IPSCs was smaller in response to SC11, SC12, and SC13 compared to DAMGO as well as morphine (Figure 2E). The mean time course of the response to $10 \mu \mathrm{M}$ SC13 is shown in Figure 2F. Together these effects are consistent with the SC11-13 compounds acting as partial agonists, at this synapse.

\section{SC11-13 form different interactions with MOR compared to morphine and buprenorphine}

To provide a structural context to the observed pharmacological differences between kratom alkaloids and classical opioid drugs, such as morphine and buprenorphine, we carried out a statistical analysis of the interactions formed between MOR residues and each of the compounds included in this manuscript, during molecular dynamics (MD) simulations of ligand-receptor complexes embedded in hydrated 1-palmitoyl-2-oleoyl phosphatidyl choline (POPC) bilayers. DAMGO and fentanyl were excluded from this analysis because of their different chemical 
composition and expected unique mode of binding with respect to the other molecules in the data set. The MD simulations of SC1, SC3, SC4, SC11, SC12, SC13, 11F, ${ }^{37,38}$ morphine, and buprenorphine (See Appendix 1-Table 5 for efficacy data), were carried out using the same simulation parameters and protocol used in our previous work on $7 \mathrm{OH}$ and mitragynine. ${ }^{39} \mathrm{~A}$ statistical analysis of structural interaction fingerprints (SIFts) derived from these simulations and whose average probabilities are listed in Appendix 1-Table 6 for each ligand, yielded 8 statistical models that best recapitulate the negative logarithm of experimental $G$ protein $E_{\max }$ values obtained for each ligand (see Appendix 1-Figure 4, Gi-1 $\mathrm{E}_{\max }$ was used for ligands). These models correspond to the top quartile of $\mathrm{R}^{2}$ validation on the full training set and the lowest root-meansquare error (RMSE) on the leave-one-out (LOO) validation (red dots in Appendix 1-Figure 3). According to this modeling and the calculated average positive coefficients reported in Appendix 1-Table 7, the efficacy of SC11-13 ligands and buprenorphine is reduced because of specific apolar interactions these ligands form with Y75(1.39), N127(2.63), I144(3.29), C217(45.50), and W133(23.50). On the other hand, the efficacy of SC11-13 is enhanced (negative coefficients) by specific apolar and edge-to-face aromatic interactions these ligands form with H319 (7.36). The aforementioned residue numbers refer to the murine MOR sequence and dot-separated numbers in parenthesis refer to the Ballesteros-Weinstein generic numbering scheme ${ }^{40}$ when located in transmembrane (TM) helices and the Isberg's numbering scheme ${ }^{41}$ when in loops. The first number in these schemes refers either to a helix (e.g., 3 refers to TM3) or a loop (e.g., " 45 " refers to the loop between TM4 and TM5) to which that residue belongs, whereas the second number represents the residue position relative to the most conserved residue in the helix, which is always defined by the number 50 . 
Notably, as suggested by the coefficient values reported in Appendix 1-Table 8, and illustrated in Appendix 1-Figure 2 by comparing binding modes (Appendix 1-Figure 2A) and average SIFts of SC11-13 with SIFts calculated for morphine (Appendix 1-Figure 2B), the SC1113 ligands show higher probability of interacting with Y75(1.39), N127(2.63), I144(3.29), H319(7.36), C217(45.50), and W133(23.50), but much lower probability of interacting with H297(6.52), compared to morphine.

\section{SC13 shows MOR dependent antinociception with reduced adverse effects}

The lead MOR-selective agonist SC13 was characterized in C57BL/6J mice for antinociception, respiratory depression, locomotor effects, inhibition of gastrointestinal transit, and reward or dysphoria (measured using the conditioned place preference or aversion assay (CPP/CPA)).

When administered subcutaneously (sc), SC13 showed dose-dependent antinociception in mice in the radiant heat $55^{\circ} \mathrm{C}$ tail withdrawal assay, with peak effect at 20 min and an $\mathrm{ED}_{50}$ (and 95\% CI) value of $3.05(1.75-5.27) \mathrm{mg} / \mathrm{kg}$, sc (Figure 3A). Thus, SC13 potency was similar to that of morphine $\left(\mathrm{ED}_{50}=2.48(1.57-3.87) \mathrm{mg} / \mathrm{kg}, \mathrm{sc}\right)^{23}$, consistent with its roughly comparable Gi-1 potency $\left(\mathrm{EC}_{50}=145 \mathrm{nM}\right.$ compared to morphine $\left.\left(\mathrm{EC}_{50}=51 \mathrm{nM}\right)\right)$ as well as in BRET-Nb33 assays $\left(\mathrm{EC}_{50}\right.$ of morphine=584 $\mathrm{nM}$ and 1644 and $\mathrm{EC}_{50}$ of $\mathbf{S C 1 3}=12 \mathrm{nM}$ and $730 \mathrm{nM}$ at $\mathrm{mMOR}$ and hMOR respectively) for both drugs. Opioid receptor selectivity of SC13-mediated antinociception was assessed in transgenic knock-out (KO) mice lacking MOR, KOR or DOR. SC13 antinociception was significantly reduced in MOR KO mice (Figure 3B). DOR KO did not produce significant differences in effect from WT mice, and while KOR contributions were trending towards significance, they did not reach statistical threshold. Blockage of SC13 antinociception in MOR KO was significantly greater compared to DOR KO and KOR 
KO mice supporting the conclusion that SC13 antinociception was predominantly MORmediated. The results were also consistent with SC13 selectivity seen in Gi-1 BRET assays.

At doses 5-fold higher than their $\mathrm{ED}_{50}$ antinociceptive values, SC13 (15 mg/kg, sc) showed no signs of CPP or CPA whereas morphine $(10 \mathrm{mg} / \mathrm{kg}, I P)$ showed CPP and U50,488H showed CPA, as expected (Figure 3C). In GI transit assays tested at ED 80 antinociceptive doses, morphine inhibited gastrointestinal passage, while the effects of SC13 and saline were indistinguishable from each other (Figure 3D).

Compounds were next evaluated for respiratory depression and hyperlocomotion in mice using the computer-controlled Comprehensive Lab Animal Monitoring System (CLAMS) assay ${ }^{26}$. At a dose 15-fold higher than the antinociceptive $\mathrm{ED}_{50}$ value, SC13 showed no statistically significant respiratory effects, whereas morphine at an equivalent dosage (30 mg/kg, sc) showed significant respiratory depression for $60 \mathrm{~min}$ after administration (Figure 3E). Similarly, SC13 showed no hyperlocomotion at a dose 15 -fold higher than the antinociceptive $\mathrm{ED}_{50}$ value, in contrast to the prototypic MOR agonist morphine, which showed hyperlocomotion effects at doses 5-fold and 15-fold higher than its antinociceptive ED 50 value (Figure 3F).

Oral administration of $\mathbf{S C 1 3}\left(10 \mathrm{mg} / \mathrm{kg}\right.$, po) also showed antinociceptive efficacy $\left(\mathrm{E}_{\max }=\right.$ $80 \% \mathrm{MPE}$ at $30 \mathrm{~min}$ ) nearly equivalent to the efficacy of subcutaneous SC13 at the same dose $\left(E_{\max }=100 \%\right.$ at $\left.20 \mathrm{~min}\right)$, suggesting possibly good plasma exposure through the oral route. (Figure 3G). The antinociceptive time courses observed following administration by each route were also similar. The results are consistent with the good oral activity usually seen with the mitragynine template ${ }^{19,42}$ and reported metabolic stability of this template. ${ }^{19}$ Overall, the MOR partial agonist, SC13 with an efficacy of $\sim 10 \%$ (BRET-Nb33 assays, Appendix 1-Figure 1J) in murine MOR showed equi-efficacious antinociception compared to morphine with 70\% efficacy ((BRET-Nb33 
assays, Appendix 1-Figure 1J) while showing greatly attenuated opioid-induced adverse effects in mice.

\section{DISCUSSION}

Opioids and their activation of opioid receptors continue to be investigated as treatments of acute to moderate pain despite their numerous and often serious adverse effects. In recent years, biased agonism has been proposed as an avenue to dissociate respiratory depression from analgesia. ${ }^{4-45}$ However, recent studies have raised concerns about this hypothesis. ${ }^{44,46,47}$ Mice lacking $\beta$-arrestin2 were reported to retain respiratory depression mediated by morphine, ${ }^{48}$ and mice with MOR C-tail mutations that inhibit arrestin recruitment still show respiratory depression as well as tolerance $\mathrm{e}^{49}$ in contrast to previous reports ${ }^{50}$.

Extending these concerns, we had previously reported the kratom alkaloids mitragynine, $7 \mathrm{OH}$ and mitragynine pseudoindoxyl to be G-protein biased agonists. ${ }^{17,18,22}$ However, recent reports with other putative G-protein biased agonists such as SR17018, PZM21 and TRV130 have suggested that these ligands are in fact MOR partial agonists with low intrinsic efficacy compared to DAMGO when assessed in a less amplified G-protein signaling system. ${ }^{5}$

Here we used the mitragynine template to test this low efficacy partial agonism hypothesis, and whether such an approach can lead to MOR agonists with reduced side effect liability but maintained analgesia. We developed a SAR based on the aromatic ring of mitragynine, $7 \mathrm{OH}$ template and identified three C9-diversified analogs SC11, SC12 and SC13.

In amplified cAMP assays, our analogs showed full agonism at MOR compared to DAMGO. Similar observations of cAMP measurements greatly overestimating efficacy in the presence of receptor reserve have been reported previously ${ }^{51}$ and are consistent with receptor 
theory. ${ }^{52}$ Using a less amplified TRUPATH assay, we find that the three lead analogs have less efficacy relative to DAMGO, fentanyl and morphine but higher efficacy than buprenorphine, a well characterized partial agonist at MOR. ${ }^{53}$

The lead analogs, SC11-13 also showed arrestin recruitment with poor potency when assessed using TANGO (an assay with amplified signaling), but this $\beta$-arrestin2 recruitment activity was significantly reduced or altogether absent when quantified in the less amplified DiscoverX Pathhunter or BRET-based assays.

Typical opioid receptor functional assays that utilize cAMP and $\left[{ }^{35} \mathrm{~S}\right] \mathrm{GTP} \gamma \mathrm{S}$ often fail to account for simultaneous signaling through various $\mathrm{G} \alpha$ subunits. ${ }^{54}$ It is difficult to recapitulate the complexity of in vivo signaling due to cell line limitations, namely, the differential expression of specific $\mathrm{G} \alpha$ subunits in various cell types. For example, $\mathrm{CHO}$ and $\mathrm{HEK}$ cell lines show differential expression of $\mathrm{Gz}$ and Gao subtypes. ${ }^{33}$ The BRET based TRUPATH assay enabled us to study activity of each of the G $\alpha$-subtypes in isolation. ${ }^{32}$ We determined that SC11-13 show lower efficacy than DAMGO, morphine, or fentanyl at each Gi/o subtype. At GoA and GoB, buprenorphine $\left(\mathrm{E}_{\max }=65-66 \%\right)$ and SC11-13 $\left(\mathrm{E}_{\max }=63-75 \%\right)$ had comparable intrinsic efficacy, which is of interest since the most abundant $\mathrm{G} \alpha$ subunit in the brain is GoA. ${ }^{55}$ Similarly at Gz too, buprenorphine $\left(\mathrm{E}_{\max }=81 \%\right)$ and our synthetic analogs SC11-13 $\left(\mathrm{E}_{\max }=79-86 \%\right)$ had similar efficacies.

In mice, SC13 was equipotent to morphine in antinociception assays. The role of $\mathrm{Gz}$ in opioid induced antinociception is poorly understood, although Gz knock-out (KO) mice have reduced opioid antinociception in a tail withdrawal test similar to the one used here, ${ }^{56}$ and DAMGO preferentially signals through Gz over Gi-2 in periaqueductal grey membranes. ${ }^{57}$ The role these Ga subtypes play in in vivo responses to SC11-13 is uncertain at this point; however the overall 
G $\alpha$-subtype efficacy profile does appear similar to the well characterized MOR partial agonist buprenorphine.

The partial agonism of SC11-13 was confirmed in a BRET-based Nb33 recruitment, an assay which has been shown to accurately reflect efficacy without signal amplification ${ }^{5}$. In these assays, using either hMOR or mMOR, SC11-13 was found to have similar efficacy to buprenorphine. While the putatively biased MOR ligands SR17018, TRV130 and PZM21 were not evaluated in our study, we infer that SC11-13 may have efficacy similar to SR17018 (20\%) but lower than either TRV130 (42\%) or PZM21 (38\%). ${ }^{5}$ Similarly, SC11-13 were found to have lower intrinsic efficacy than DAMGO and morphine in VTA synaptic effects, corroborating our cell line-based findings in an endogenous system with physiologically relevant levels of receptor reserve. Behaviorally, SC13 showed MOR-dependent antinociception and potency similar to morphine while showing none of the adverse effects associated with morphine at equianalgesic equivalent doses. This pattern is reminiscent of that of buprenorphine, which is known to show a ceiling effect in respiratory depression ${ }^{58}$ and is generally considered a safer analgesic ${ }^{59}$ although it still shows hyperlocomotion ${ }^{60}$, constipation ${ }^{60}$ and reward-like behavior in rodents. ${ }^{61}$ Of note, it is not yet clear if the preferable properties of buprenorphine result solely from its partial agonism at $\mathrm{MOR}^{5,62}$ or because of its additional actions such as $\mathrm{DOR}^{60}$ and $\mathrm{KOR}^{60}$ antagonism or weak NOP agonism ${ }^{63}$. Buprenorphine's pharmacology is further complicated by its metabolism to norbuprenorphine ${ }^{64,65}$ (a lower potency but much higher efficacy metabolite) as well as other active metabolites such as buprenorphine 3-glucuronide ${ }^{66}$. Furthermore, the oral activity of buprenorphine is limited due to its metabolism to norbuprenorphine ${ }^{67}$, unlike SC13 which under tested conditions in mice is orally as active as when given subcutaneously. Together, the present 
results suggest additional benefits of SC13 over buprenorphine, while also validating the further investigation of MOR-selective partial agonists as analgesics with fewer liabilities.

In summary, using the mitragynine template and unamplified signaling assays we identified partial MOR agonists that appear to functionally dissociate MOR-dependent analgesia from locomotor and respiratory depression. While additional mechanisms extending beyond MOR and G $\alpha$ signaling cannot be ruled out, our studies corroborate findings by Gillis et $\mathrm{al}^{5}$ suggesting that low G protein efficacy at MOR may lead to a favorable therapeutic window of new opioids.

\section{ACKNOWLEDGEMENTS}

SM and DS are supported by funds from NIH grants DA045884, DA046487. SM is supported by DA048379. JAJ is supported by a grant from the Hope for Depression Research Foundation. MF is supported by NIH grants DA034049 and DA045884. Computations were run on resources available through the Office of Research Infrastructure of the National Institutes of Health under award numbers S10OD018522 and S10OD026880 (to the Icahn School of Medicine at Mount Sinai), as well as the Extreme Science and Engineering Discovery Environment under MCB080077 (to MF), which is supported by National Science Foundation grant number ACI1548562. RVR is supported by NIH grants AA026949, DA045897, AA025368. EBM is supported by funds from the State of California for medical research on alcohol and substance abuse through the University of California, San Francisco.

Competing Interest Statement: The authors declare the following competing financial interest(s): S.M. is a co-founder of Sparian Inc. D.S and J.A. J. are co-founders of Kures. SM, DS and JAJ are inventors on patent applications related to mitragynine analogs, which may lead to royalties or other licensing revenues from future commercial products. 
bioRxiv preprint doi: https://doi.org/10.1101/2021.04.22.440994; this version posted May 7, 2021. The copyright holder for this preprint (which was not certified by peer review) is the author/funder, who has granted bioRxiv a license to display the preprint in perpetuity. It is made available under aCC-BY-NC-ND 4.0 International license.

\section{METHODS}




\begin{tabular}{|c|c|c|c|c|}
\hline \multicolumn{5}{|c|}{ Key Resources Table } \\
\hline $\begin{array}{l}\text { Reagent } \\
\text { type } \\
\text { (species) } \\
\text { or } \\
\text { resource }\end{array}$ & Designation & $\begin{array}{l}\text { Source or } \\
\text { reference }\end{array}$ & Identifiers & $\begin{array}{l}\text { Additional } \\
\text { information }\end{array}$ \\
\hline $\begin{array}{l}\text { strain, strain } \\
\text { background } \\
\text { (Mus } \\
\text { musculus, } \\
\text { male) }\end{array}$ & C57BL6 & Jackson labs & & \\
\hline $\begin{array}{l}\text { strain, strain } \\
\text { background } \\
\text { (Mus } \\
\text { musculus, } \\
\text { male) }\end{array}$ & $\begin{array}{l}\text { MOR KO } \\
\text { KOR KO } \\
\text { DOR KO }\end{array}$ & Jackson labs & & \\
\hline cell line & HEK293T & ATCC & $\begin{array}{c}\text { Cat\#CRL- } \\
3216\end{array}$ & \\
\hline cell line & HTLA & $\begin{array}{c}\text { Dr. Richard } \\
\text { Axel, } \\
\text { Columbia Univ }\end{array}$ & $\begin{array}{c}\text { PMID:258950 } \\
59\end{array}$ & \\
\hline cell line & $\mathrm{CHO}$ & ATCC & $\begin{array}{c}\text { ATCC }{ }^{\circledR} \\
\text { CCL-61 }{ }^{\mathrm{TM}}\end{array}$ & \\
\hline $\begin{array}{l}\text { transfected } \\
\text { construct } \\
\text { (Mus } \\
\text { musculus) }\end{array}$ & $\begin{array}{l}\text { mMOR-1, } \\
\text { mKOR-1 }\end{array}$ & $\begin{array}{l}\text { Methods Mol } \\
\text { Med 84:17-28 }\end{array}$ & $\mathrm{N} / \mathrm{A}$ & \\
\hline $\begin{array}{l}\text { transfected } \\
\text { construct } \\
\text { (Mus } \\
\text { musculus) }\end{array}$ & mDOR-1 & $\begin{array}{c}\text { Cell Mol } \\
\text { Neurobiol. } \\
2020 \\
\text { PMID: } 324247 \\
71\end{array}$ & $\mathrm{~N} / \mathrm{A}$ & \\
\hline $\begin{array}{l}\text { transfected } \\
\text { construct } \\
\text { (human) }\end{array}$ & $\begin{array}{l}\text { Transfected } \\
\text { construct } \\
\text { (Homo } \\
\text { sapiens) }\end{array}$ & $\begin{array}{l}\text { human DOR, } \\
\text { KOR, MOR in } \\
\text { pcDNA } 3.1\end{array}$ & $\begin{array}{l}\text { PMID: } 29307 \\
491\end{array}$ & \\
\hline $\begin{array}{l}\text { chemical } \\
\text { compound, } \\
\text { drug }\end{array}$ & Lipofectamine & Invitrogen & & \\
\hline
\end{tabular}




\begin{tabular}{|c|c|c|c|c|}
\hline $\begin{array}{l}\text { chemical } \\
\text { compound, } \\
\text { drug }\end{array}$ & Lipofectamine & Invitrogen & & \\
\hline $\begin{array}{l}\text { chemical } \\
\text { compound, } \\
\text { drug }\end{array}$ & DAMGO & Abcam & $\begin{array}{c}\text { CAS\#:78123- } \\
71-4\end{array}$ & \\
\hline $\begin{array}{l}\text { chemical } \\
\text { compound, } \\
\text { drug }\end{array}$ & PEI & Fischer & $\begin{array}{c}\text { CAS\#: } \\
\text { NC1014320 }\end{array}$ & \\
\hline $\begin{array}{l}\text { chemical } \\
\text { compound, } \\
\text { drug }\end{array}$ & FBS & Corning & $\begin{array}{c}\text { CAS\#: 35- } \\
\text { 010-CV }\end{array}$ & \\
\hline other & $\begin{array}{l}\text { Sodium } \\
\text { Luciferin }\end{array}$ & Goldbio & $\begin{array}{c}\text { Cat\#LUNCA- } \\
1 \mathrm{~g}\end{array}$ & \\
\hline other & $\begin{array}{c}\text { Dulbecco's } \\
\text { Modified } \\
\text { Eagle Medium }\end{array}$ & $\begin{array}{c}\text { Life } \\
\text { Technologies }\end{array}$ & $\begin{array}{c}\text { CAS\#:11965- } \\
118\end{array}$ & \\
\hline other & BrightGlo & Promega & Cat\#E2620 & \\
\hline other & $\begin{array}{c}\text { Coelenterazin } \\
\text { e H }\end{array}$ & $\begin{array}{l}\text { Dalton } \\
\text { Pharma } \\
\text { Services }\end{array}$ & $\begin{array}{c}\text { CAS\#: DC- } \\
001437\end{array}$ & \\
\hline other & Pen/Strep & Corning & $\begin{array}{c}\text { CAS\#: 30- } \\
002-\mathrm{Cl}\end{array}$ & \\
\hline $\begin{array}{l}\text { software, } \\
\text { algorithm }\end{array}$ & Prism & GraphPad & 7.0 & \\
\hline
\end{tabular}




\begin{tabular}{|l|c|c|c|c|}
\hline other & $\begin{array}{c}\text { Coelenterazine } \\
\mathrm{H}\end{array}$ & $\begin{array}{c}\text { Dalton } \\
\text { Pharma } \\
\text { Services }\end{array}$ & $\begin{array}{c}\text { CAS\#: DC- } \\
001437\end{array}$ & \\
\hline other & Pen/Strep & Corning & $\begin{array}{c}\text { CAS\#: 30- } \\
\text { 002-Cl }\end{array}$ & \\
\hline software, & Prism & GraphPad & 7.0 & \\
\hline
\end{tabular}

Drugs and Chemicals: Opiates were provided by the Research Technology Branch of the National Institute on Drug Abuse (Rockville, MD). Selective opioid antagonists were purchased from Tocris Bioscience. Miscellaneous chemicals and buffers were purchased from SigmaAldrich. Kratom "Red Indonesian Micro Powder" was purchased from Moon Kratom (Austin, TX).

\section{Chemistry:}

All chemicals were purchased from Sigma-Aldrich Chemicals and used without further purification. Reactions were carried out in flame-dried reaction flasks under Ar. Reaction mixtures were purified by silica flash chromatography on E. Merck 230-400 mesh silica gel 60 using a Teledyne ISCO CombiFlash $\mathrm{R}_{\mathrm{f}}$ instrument with UV detection at 280 and $254 \mathrm{~nm}$. RediSep $\mathrm{R}_{\mathrm{f}}$ silica gel normal phase columns were used. The yields reported are isolated yields. NMR spectra were recorded on a Varian 400/500 MHz NMR spectrometer. NMR spectra were processed with MestReNova software. The chemical shifts were reported as $\delta$ ppm relative to TMS using residual solvent peak as the reference unless otherwise noted $\left(\mathrm{CDCl}_{3}{ }^{1} \mathrm{H}: 7.26,{ }^{13} \mathrm{C}\right.$ : 77.3). Peak multiplicity is reported as follows: s, singlet; $d$, doublet; t, triplet; q, quartet; m, multiplet. Coupling constants $(J)$ are expressed in Hz. High resolution mass spectra were obtained 
on a Bruker Daltonics 10 Tesla Apex Qe Fourier Transform Ion Cyclotron Resonance-Mass Spectrometer by electrospray ionization (ESI). Accurate masses are reported for the molecular ion $[\mathrm{M}+\mathrm{H}]^{+}$.

\section{In vitro pharmacology assays:}

\section{cAMP and TANGO. ${ }^{34}$}

To measure Glo-sensor $\mathrm{G}_{\alpha i}$-mediated cAMP inhibition, HEK 293T (ATCC CRL-11268) cells were co-transfected with human opioid receptor (hMOR, hKOR and hDOR) along with a luciferase-based cAMP biosensor and the assay was performed as reported previously. ${ }^{34}$ Next, arrestin recruitment Tango assay was carried out using HTLA cells expressing TEV fused- $\beta$ Arrestin2 were transfected with human opioid receptors (hMOR, hKOR or hDOR) as the Tango construct by following previously reported protocols. ${ }^{34}$

BRET2 assays $^{32}$. Cells were plated either in 6-well dishes at a density of 700,000-800,000 cells per well, or $10 \mathrm{~cm}$ dishes at 7-8 million cells per dish. Cells were transfected $2-4 \mathrm{~h}$ later, using a 1:1:1:1 DNA ratio of receptor:G $\alpha$-RLuc8:G $\beta: G \gamma$-GFP2 (100 ng per construct for 6-well dishes, $750 \mathrm{ng}$ per construct for $10 \mathrm{~cm}$ dishes), except for the G $\gamma$-GFP2 screen, where an ethanol coprecipitated mixture of G $\beta 1-4$ was used at twice its normal ratio (1:1:2:1). Transit 2020 (Mirus Biosciences) was used to complex the DNA at a ratio of $3 \mu 1$ Transit per $\mu$ g DNA, in OptiMEM (Gibco-ThermoFisher) at a concentration of 10 ng DNA per $\mu$ l OptiMEM. The next day, cells were harvested from the plate using Versene (0.1 M PBS + 0.5 mM EDTA, $\mathrm{pH} 7.4)$ and plated in polyD-lysine-coated white, clear-bottom 96-well assay plates (Greiner Bio-One) at a density of 30,000-50,000 cells per well. One day after plating in 96-well assay plates, white backings (PerkinElmer) were applied to the plate bottoms, and growth medium was carefully aspirated and replaced immediately with $60 \mu 1$ of assay buffer (1× Hank's balanced salt solution 
$(\mathrm{HBSS})+20 \mathrm{mM}$ HEPES, pH 7.4), followed by a $10 \mu \mathrm{l}$ addition of freshly prepared $50 \mu \mathrm{M}$ coelenterazine 400a (Nanolight Technologies). After a 5 min equilibration period, cells were treated with $30 \mu \mathrm{l}$ of drug for an additional 5 min. Plates were then read in an LB940 Mithras plate reader (Berthold Technologies) with $395 \mathrm{~nm}$ (RLuc8-coelenterazine 400a) and $510 \mathrm{~nm}$ (GFP2) emission filters, at integration times of $1 \mathrm{~s}$ per well. Plates were read serially six times, and measurements from the sixth read were used in all analyses. BRET2 ratios were computed as the ratio of the GFP2 emission to RLuc8 emission.

BRET-Based Nb33 Recruitment Assays. Experiments were performed as described previously. ${ }^{68}$ Briefly, transfected cells were dissociated and resuspended in phosphate-buffered saline. Cells were added to a black-framed, white well 96-well plate (no. 60050; Perkin Elmer; Waltham, MA, USA). At time zero, the luciferase substrate coelenterazine $\mathrm{H}(5 \mu \mathrm{M})$ was added to each well. Ligands were added after 5 min, then BRET signal was measured 10 min later. BRET measurements were performed using a PHERAstar FS plate reader (BMG Labtech, Cary, NC, USA). The BRET signal was calculated as the ratio of the light emitted by the mVenus acceptor $(510-540 \mathrm{~nm})$ over the light emitted by the NanoLuc donor $(475 \mathrm{~nm})$. Dose-response curves were fit using a three-parameter logistic equation in GraphPad Prism 8 (Graphpad Software, La Jolla, CA, USA). All experiments were repeated in at least three independent trials each with triplicate determinations.

Materials. HEK-293T cells were obtained from the American Type Culture Collection (Rockville, $\mathrm{MD}$, USA) and were cultured in a $5 \% \mathrm{CO}_{2}$ atmosphere at $37^{\circ} \mathrm{C}$ in Dulbecco's Modified Eagle Medium (DMEM, high glucose, \#11965; Life Technologies; Grand Island, NY, USA) supplemented with 10\% Fetal Bovine Serum (\#35-010-CV, Corning, Corning, NY, USA) and $100 \mathrm{IU} \mathrm{ml}^{-1}$ penicillin and $100 \mu \mathrm{g} \mathrm{ml}^{-1}$ streptomycin (\#30-002-CI; Corning, Corning, NY, USA). 
The following chemicals were used without further modification: [D-Ala $\left.{ }^{2}, \mathrm{~N}-\mathrm{Me}-\mathrm{Phe}^{4}, \mathrm{Gly}^{5}-\mathrm{ol}\right]-$ Enkephalin (DAMGO; \#78123-71-4,Abcam,Cambridge, United Kingdom), Buprenorphine hydrochloride (\#B9275, Sigma-Aldrich,St. Louis, MO, USA), Morphine sulfate (\#M1167, Spectrum Chemicals,New Brunswick, NJ, USA), Coelenterazine H (\#DC-001437, Dalton Pharma Services, Toronto, ON, Canada), Polyethylenimine (PEI; \#NC1014320, Polysciences, Warrington, PA, USA).

DNA Constructs. The expression vector coding for mouse MOR tagged at the C-terminus with Nanoluc (mMOR-nluc) by a Gly-Ser linker was constructed using standard techniques in molecular biology and confirmed by DNA sequencing (Psomagen, Brooklyn, NY, USA). Briefly, two DNA inserts were PCR amplified, one coding for mMOR with an $\mathrm{N}$ terminal signal peptide followed by a FLAG tag, and the other coding for NanoLuc. The two inserts were joined by PCR amplification and the resulting insert coding mMOR-nluc was cloned into the Hind III and Xho I sites of pcDNA3.1 (+) (\#V79020, ThermoFisher Scientific, Waltham, MA, USA). The plasmid coding for human MOR-nanoluc (hMOR-nluc) was a gift from Dr. Nevin Lambert at the Medical College of Georgia. The plasmid coding for the nanobody-33-Venus (Nb-33) construct ${ }^{5}$ was a gift from Dr. Meritxell Canals at the University of Nottingham.

Transfection. A total of $5 \mu \mathrm{g}$ of cDNA was transiently transfected into HEK-293T cells $(2 \times$ $10^{6}$ cells per plate) in $10 \mathrm{~cm}$ dishes $(1 \mu \mathrm{g}$ receptor-nluc, and $4 \mu \mathrm{g} \mathrm{Nb}-33-$ Venus $)$, using PEI in a 6:1 ratio (diluted in DMEM). Cells were maintained in the HEK-293T media described above. Experiments were performed 48 hours after transfection. 
Pathhunter assays. $\beta$-arrestin recruitment assays were performed as previously described. ${ }^{69}$ In brief, CHO-K1-human $\mu \mathrm{OR}$ cells (DiscoverX) were grown to confluency and seeded at a density of 2500 cells in a low-volume 384 well plate $\left(10 \mu \mathrm{L}\right.$ per well). After incubating overnight at $37^{\circ} \mathrm{C}$ with $5 \% \mathrm{CO}_{2}$, a $5 \mathrm{X}$ dilution series of compounds prepared in opti-MEM was added $(2.5 \mu \mathrm{L}$ per well) and incubated at $37^{\circ} \mathrm{C}$ for an additional 90 minutes. PathHunter detection reagent (DiscoverX) was prepared according to the manufacturer's protocol and added (6 $\mu \mathrm{L}$ per well). Following a 60-minute, room temperature incubation in the dark, the chemiluminescence signal was measured using a FlexStation3 plate reader.

Competitive radioligand binding assay: Membrane isolation and binding assays were performed as previously described. ${ }^{70}$ In brief, membranes were isolated from $\mathrm{CHO}$ cells stably expressing the $\mu$ OR (DiscoverX). To harvest membranes, cells were dislodged from a T75 flask and pelleted via centrifugation at $1300 \mathrm{rpm}$ for 5 minutes at $20{ }^{\circ} \mathrm{C}$ (Eppendorf 5804R). The supernatant was aspirated, and the cell pellet was resuspended in assay buffer $(50 \mathrm{mM}$ Tris $\mathrm{HCl}, 10 \mathrm{mM} \mathrm{MgCl}, 1$ mM EDTA, pH 7.4) and thoroughly sonicated (Qsonica XL-2000, level 3.) Membranes were isolated from the resulting suspension via ultracentrifugation at $20,000 \mathrm{rpm}$ for 30 minutes at $4{ }^{\circ} \mathrm{C}$ (Optima L-100 XP Ultracentrifuge, SW 41 Ti, 41,000 rpm rotor). The supernatant was aspirated, and the resulting membrane pellets were resuspended in assay buffer on ice by thorough sonication, pushed through a 28-gauge needle, and stored in $1 \mathrm{~mL}$ aliquots at $-80{ }^{\circ} \mathrm{C}$ until day of binding assay. Each T75 flask yielded approximately 1, $1 \mathrm{~mL}$ aliquot. On assay days, a 4X dilution series of compounds made in assay buffer was added to a 96 well plate $(50 \mu \mathrm{L}$ per well, added in duplicate.) Tritiated radioligand ([3H]DAMGO for MOR) diluted in assay buffer was added to the 96 well plate $(50 \mu \mathrm{L}$ per well) at a concentration near the EC80 value for the receptor: $2.325 \mathrm{nM}$ [3H]DAMGO. Next, a membrane aliquot was thawed on ice, diluted in assay buffer (1:10, 
approximate protein concentration of $70 \mu \mathrm{g} / \mathrm{mL}$ ) followed by thorough sonication, and the resulting membrane suspension was added to the plate $(100 \mu \mathrm{L}$ per well, approximately $7 \mu \mathrm{g}$ protein). After adding the membrane suspension, the plate contents were incubated at room temperature for 90 minutes. The membrane mixture was then filtered over a $0.3 \%$ PEI pre-treated GF-B/C plate (\#6005174, Perkin Elmer, Waltham, MA, USA) with a cell harvester system. After the GF-B/C plate was dried overnight, scintillation fluid was added (50 $\mu \mathrm{L}$ per well, Ultimagold uLLT) and radioactivity was measured using a scintillation counter (Hewlett Packard TopCount NXT). For the competitive binding assays, all data were analyzed with GraphPad 8 (GraphPad Prism software, La Jolla, CA). Both assays were run in duplicate in a minimum of three, independent assays. Data from each independent assay were normalized to a positive control and then all independent assays were averaged and compiled into a composite Figure. Data is presented as means \pm SEM.

\section{EPhys assays:}

Electrophysiology Animals. Eight male Sprague-Dawley rats were used for whole cell electrophysiology recordings, procedures conducted in strict accordance with the recommendations of the National Institutes Health $(\mathrm{NIH})$ in the Guide for the Care and Use of Laboratory Animals. Research protocols were approved by the Institutional Animal Care and Use Committee (University of California at San Francisco, CA), approval ID AN183735-01B.

Slice preparation and $e x$ vivo whole cell electrophysiology. ${ }^{71}$ Rats were anesthetized with isoflurane and their brains were removed. Horizontal brain slices (200 $\mu \mathrm{m}$ thick) containing the VTA were prepared using a vibratome (Leica Microsystems). Slices were submerged in artificial 
CSF solution containing (in mM): $126 \mathrm{NaCl}, 2.5 \mathrm{KCl}, 1.2 \mathrm{MgCl}, 1.4 \mathrm{NaH}_{2} \mathrm{PO}_{4}, 2.5 \mathrm{CaCl}_{2}, 25$ $\mathrm{NaHCO}_{3}$, and 11 glucose saturated with $95 \% \mathrm{O}_{2}-5 \% \mathrm{CO}_{2}$ and allowed to recover at $33^{\circ} \mathrm{C}$ for at least $1 \mathrm{~h}$. Individual slices were visualized under a Zeiss AxioExaminer.D1 with differential interference contrast, Dodt, and near infrared optics using a monochrome Axiocam 506 or under a Zeiss Axioskop FS 2 plus with differential interference contrast optics and infrared illumination equipped with a Zeiss Axiocam MRm (Zeiss International). Whole-cell patch-clamp recordings were made at $33^{\circ} \mathrm{C}$ using $2.5-5 \mathrm{M} \Omega$ pipettes containing (in $\mathrm{mM}$ ) $128 \mathrm{KCl}, 20 \mathrm{NaCl}, 1 \mathrm{MgCl}_{2}, 1$ EGTA, 0.3 $\mathrm{CaCl}_{2}, 10 \mathrm{HEPES}, 2 \mathrm{MgATP}$, and $0.3 \mathrm{Na}{ }_{3} \mathrm{GTP}$ (pH 7.2, osmolarity adjusted to 275). Signals were amplified using an IPA amplifier with SutterPatch software (Sutter Instrument) filtered at $1 \mathrm{kHz}$ and collected at $10 \mathrm{kHz}$ or using an Axopatch 1-D (Molecular Devices), filtered at $2 \mathrm{kHz}$, and collected at $20 \mathrm{kHz}$ using custom written procedures for IGOR Pro (Wavemetrics). Cells were recorded in voltage-clamp mode (V -70 mV). Series resistance and input resistance were sampled throughout the experiment with $4 \mathrm{mV}, 200 \mathrm{~ms}$ hyperpolarizing steps. GABA receptor mediated inhibitory postsynaptic potentials (IPSCs) were pharmacologically isolated with 6,7-dinitroquinoxaline-2,3(1H,4H)-dione (DNQX: $10 \mu \mathrm{M})$. Stimulating electrodes were placed 80-250 $\mu \mathrm{m}$ anterior or posterior to the soma of the recorded neuron. To measure drug effects on evoked IPSCs, paired pulses (50-ms interval) were delivered once every $10 \mathrm{~s}$. The IPSC amplitude was calculated by comparing the peak PSC voltage to a $2 \mathrm{~ms}$ interval just before stimulation. All drugs were bath applied. Drug effects were quantified by comparing the mean evoked IPSC amplitude during the 4 min of baseline just preceding drug application and the mean response amplitudes during minutes 4-7 of drug application.

Mice: C57BL/6J mice (20-32 g each) were obtained from Jackson Laboratories (Bar Harbor, ME). MOR KO, KOR KO and DOR KO were bred in the laboratory of Dr. McLaughlin at University 
of Florida. All mice used throughout the manuscript were opioid naïve. All mice were maintained on a 12-hour light/dark cycle with Purina rodent chow and water available ad libitum, and housed in groups of five until testing. All animal studies were preapproved by the Institutional Animal Care and Use Committees of the University of Florida, in accordance with the 2002 National Institutes of Health Guide for the Care and Use of Laboratory Animals

Antinociception. The $55^{\circ} \mathrm{C}$ warm-water tail-withdrawal assay was conducted in $\mathrm{C} 57 \mathrm{BL} / 6 \mathrm{~J}$ mice as a measure of acute thermal antinociception as described previously. ${ }^{18}$ Briefly, each mouse was tested for baseline tail-withdrawal latency prior to drug administration. Following drug administration, the latency for each mouse to withdraw the tail was measured every 10 minutes until latency returned to the baseline value. A maximum response time of 15 seconds was utilized to prevent tissue damage. If the mouse failed to display a tail-withdrawal response within 15 seconds, the tail was removed from the water and the animal was assigned a maximal antinociceptive score of $100 \%$. Data are reported as percent antinociception, calculated by the equation: $\%$ antinociception $=100 \times[($ test latency - baseline latency $) /(15-$ baseline latency $)]$. This was utilized to account for innate variability between mice. Compounds were administered subcutaneously (sc) or orally (po) and the analgesic action of compounds was assessed at the peak effect.

Respiratory Depression and Locomotor Effects Assessment. Respiration rates and spontaneous ambulation rates were monitored using the automated, computer-controlled Comprehensive Lab Animal Monitoring System (CLAMS) (Columbus Instruments, Columbus, OH) as described previously. ${ }^{26}$ Freely moving mice were habituated in closed, sealed individual apparatus cages $(23.5 \mathrm{~cm} \times 11 / 5 \mathrm{~cm} \times 13 \mathrm{~cm})$ for $60 \mathrm{~min}$ before testing. To start testing, mice were administered 
(sc) drug or vehicle and 5 min later confined to the CLAMS testing cages for $120 \mathrm{~min}$. Using a pressure transducer built into the sealed CLAMS cage, the respiration rate (breaths/min) of each occupant mouse was measured. Infrared beams located in the floor measured locomotion as ambulations, from the number of sequential breaks of adjacent beams. Data are expressed as percent of vehicle control response.

Conditioned Place Preference and Aversion. Mice were conditioned with a counterbalanced place conditioning paradigm using similar timing as detailed previously. A group of mice $(\mathrm{n}=18$ 24) were habituated to freely explore both sides of a two-compartment apparatus for 3 hours each for 2 days prior testing. The amount of time subjects spent in each of three compartments was measured over a 20 min testing period. Prior to place conditioning, the animals did not demonstrate significant differences in their time spent exploring the left vs right compartments. During each of the next 2 days, mice were administered vehicle (0.9\% saline) and consistently confined in a randomly assigned outer compartment for $20 \mathrm{~min}$, half of each group in the right chamber, half in the left chamber. Four hours later, mice were administered drugs morphine $(10 \mathrm{mg} / \mathrm{kg} / \mathrm{d}, I P)$, U50,488h (30 mg/kg/d, IP), SC $13(15 \mathrm{mg} / \mathrm{kg} / \mathrm{d}, \mathrm{sc})$ and were confined to the opposite compartment for $20 \mathrm{~min}$. Conditioned place preference data are presented as the difference in time spent in drug- and vehicle-associated chambers and were analyzed via repeated measures two-way ANOVA with the difference in time spent on the treatment- vs vehicle-associated side as the dependent measure and conditioning status as the between groups factor. Where appropriate, Tukey's HSD or Sidak's multiple comparison post hoc tests were used to assess group differences. Effects were considered significant when $\mathrm{p}<0.05$. All effects are expressed as mean $\pm \mathrm{SEM}$.

Assessment of Gastrointestinal Transit. C57BL/6J mice (8 per drug treatment) were administered morphine $(10 \mathrm{mg} / \mathrm{kg}$, sc), or saline $(0.9 \%, \mathrm{sc})$ or SC13 $(15 \mathrm{mg} / \mathrm{kg}, \mathrm{sc}) 20 \mathrm{~min}$ prior 
to oral gavage with $0.3 \mathrm{~mL}$ of a $5 \%$ aqueous solution of charcoal meal. After $3 \mathrm{~h}$, mice were euthanized and the intestines removed. The progression of charcoal through the intestines was measured as distance traveled from the jejunum to the cecum as utilized elsewhere. ${ }^{72}$

\section{Computational studies:}

\section{Molecular Docking:}

The crystal structure of active murine MOR bound to BU72 (PDB id: 5C1MF) was prepared for molecular docking of SC1, SC3, SC4, SC11, SC12, SC13, 11-F, morphine, and buprenorphine, using the protocol we recently reported in the literature for docking and simulations of kratom alkaloids, including mitragynine and $7 \mathrm{OH}$ mitragynine. ${ }^{73}$ Molecular docking of morphine and buprenorphine was achieved by overlapping core heavy atoms onto the co-crystal compound BU72. In contrast, SC1, SC3, SC4, SC11, SC12, SC13, and 11-F were aligned onto mitragynine

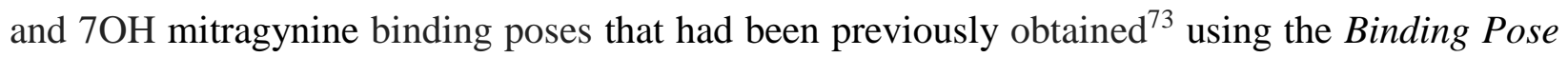
Metadynamics module in Schrödinger suite 2019-2 $2^{74}$ for metadynamics rescoring of initial docking poses obtained with DOCK6.9.

Molecular Dynamics Simulations. Unbiased MD simulations of ligand-MOR complexes embedded in a POPC bilayer and solvated in a $10 \times 10 \times 10 \AA^{3}$ orthorhombic box of simple point charge (SPC) water molecules and $0.15 \mathrm{M} \mathrm{NaCl}$ buffer in each dimension, were carried out using the OPLS3e force-field and the Desmond software within the Schrödinger suite 2019-2. ${ }^{39}$ Systems were neutralized with chloride ions using the System Builder function and missing dihedral parameters of the ligands were generated using the Force Field Builder in the Schrödinger suite. The same MD simulation parameters and protocol used in our previous work on $7 \mathrm{OH}$ 
mitragynine and mitragynine ${ }^{39}$ were used here. MD production runs consisted of four independent simulations of $250 \mathrm{~ns}$ each for each ligand-MOR complex, for a total of $9 \mu$ s new simulation data added to the previously published $2 \mu$ s simulation data collected for $7 \mathrm{OH}$-mitragynine-MOR and mitragynine-MOR complexes. ${ }^{39}$ Highly populated conformations of each ligand at MOR were obtained using the affinity propagation clustering algorithm described by Fray and Dueck ${ }^{75}$ and implemented in the Schrödinger's trj_cluster.py script. Specifically, 500 snapshots of each ligandMOR MD simulation trajectory with a stride of $2 \mathrm{~ns}$ were superimposed to a reference frame using the protein heavy atoms within $8 \AA$ of the ligand prior to clustering. Pairwise root mean square deviation (RMSD) values of the same selected group of atoms were used as input for trj_cluster.py, which yielded 39, 39, 36, 39, 41, 28, 41, 46, 36, 41, and 43 clusters for mitragynine, 7OHmitragynine, morphine, buprenorphine, SC1, SC3, SC4, SC11, SC12, SC13, and 11-F respectively. The top populated cluster in each case accounted for $4.58 \%, 5.38 \%, 8.96 \%, 6.57 \%$, $6.57 \%, 8.37 \%, 6.97 \%, 4.78 \%, 10.36 \%, 5.58 \%$ and $6.17 \%$ of the assessed simulation frames.

Structural Interaction Fingerprint (SIFt) Analysis. An in-house python script was used to generate 9-bit representations of ligand-receptor interactions formed by both backbone and sidechain atoms, and including hydrogen-bond interactions with the protein as hydrogen-bond donor (Hbond_proD) or hydrogen-bond acceptor (Hbond_proA), electrostatic interactions with positively (Elec_ProP) or negatively charged (Elec_ProN) residues, apolar interactions (carboncarbon atoms in contact), face-to-face (Aro_F2F) and edge-to-face (Aro_E2F) aromatic interactions, as well as 1-water mediated H-bond (Hbond_1wat), and 2-water mediated H-bond (Hbond_2wat). Apolar interactions were cut at $4.5 \AA$ whereas a cutoff of $4 \AA$ was considered to define aromatic and electrostatic interactions. A two-state Markov model that samples the transition matrix posterior distribution using standard Dirichlet priors for the transition 
probabilities as described by Noé et al was used to calculate the probability of each ligand-MOR interaction formed during MD simulations. ${ }^{76}$ Calculated average SIFt probabilities for each ligand are listed in Appendix 1-Table 6.

Logistic Regression Models Based on SIFTs. We modeled the negative logarithm of the G protein efficacy $E_{\max }(k)$ for each ligand $k$ as a function of the probability of ligands establishing up to three interactions $p_{i}(k)$ in the binding pocket according to the equation:

$$
E_{\text {max }}(k)=\exp \left(-\sum_{i=1}^{3} c_{i} p_{i}(k)+\varepsilon_{k}\right)
$$

where $\varepsilon_{k}$ is a normally distributed error term and $c_{i}$ are scalar coefficients. According to this equation, high probability of establishing an interaction whose coefficient $c_{i}$ is negative results in enhancing the efficacy of the ligand, while the formation of an interaction whose coefficient $c_{i}$ is positive reduces the ligand's efficacy. The models were estimated in a Bayesian framework using the STAN engine ${ }^{77}$ for all possible combinations of three interactions in the binding pocket. The accuracy and robustness of the model was assessed by calculating the $\mathrm{R}^{2}$ on the full training dataset (11 ligands), as well as the RMSE in a LOO validation. The best 8 performing models on the experimental data were those in the top quartile of $\mathrm{R}^{2}$ validation on the full training set and the lowest LOO-RMSE validation (red dots in Appendix 1-Figure 3). To summarize the effect of each of the interactions identified by these 8 models, we report the average coefficients as well as the number of times the interactions appear in the top 8 models in Appendix 1-Table 8.

\section{Chemistry:}

Synthesis of C9 analogs: Kratom "Red Indonesian Micro Powder" was purchased from Moon Kratom (Austin, TX). Mitragynine (1) was extracted from dry kratom powder using a 
modified protocol reported by Varadi et al. ${ }^{18} 500 \mathrm{~g}$ of kratom powder was used to isolate $4.5 \mathrm{~g}$ of mitragynine along with other alkaloids. 1 was converted to 9-hydroxymitragynine using $\mathrm{AlCl}_{3}$ and ethanethiol in DCM using literature repoeted procedure. ${ }^{16}$ This hydroxy compound was converted to its triflate (4) using N-Phenyl-bis(trifluoromethanesulfonimide) and $\mathrm{Et}_{3} \mathrm{~N}$ in DCM, which was subsequently used as the precursor for further reactions.

As shown in Figure 1B, 9-phenyl mitragynine (SC3) was synthesized in 65\% yield using palladium-catalyzed Suzuki coupling reaction of triflate 4 with phenylboronic acid. SC3 was then converted to the corresponding $7 \mathrm{OH}$ derivative SC11 in $33 \%$ yield using oxone ${ }^{\circledR}$ and aqueous $\mathrm{NaHCO}_{3}$. The synthesis of 9-3'-furanyl mitragynine (SC1) was accomplished by a similar palladium-catalyzed reaction of triflate 4 with 3-furanylboronic acid. Alcohol SC13 was obtained via oxidation of $\mathbf{S C 1}$ using oxone ${ }^{\circledR}$ and aqueous $\mathrm{NaHCO}_{3}$. To install the methyl group at $\mathrm{C} 9$ we used DABAL-Me 3 as methyl donor. Palladium catalyzed coupling reaction of triflate 4 with DABAL-Me 3 in presence of XPhos afforded 9-methyl mitragynine (SC4) in 68\% isolated yield. Oxidation of compound SC4 using oxone ${ }^{\circledR}$ and aqueous $\mathrm{NaHCO}_{3}$ resulted in hydroxide SC12.

Synthesis of C10 analogs: To have access to the C10 position of the mitragynine scaffold, we incorporated bromide selectively at C10 position using Takayama's protocol. ${ }^{31}$ Mitragynine (1) was converted to mitragynine-ethylene glycol adduct using PIFA and ethylene glycol (Figure 1C) followed by bromination with NBS in DMF gave 10 bromo derivative $\mathbf{5}^{31}$ in $74 \%$ yield along with $24 \%$ of 12 bromo derivative. In this adduct the indole's double bond is temporarily masked by an ethylene glycol group. The deprotection of 5 to 10 bromo mitragynine $(\mathbf{6})^{31}$ was carried out by a mild reductive condition using $\mathrm{NaBH}_{3} \mathrm{CN} .{ }^{1} \mathrm{H}$ NMR of 6 was in good agreement with the literature reported value. ${ }^{31}{ }^{1} \mathrm{H}$ NMR $(500 \mathrm{MHz}$, Chloroform- $d) \delta 7.86(\mathrm{~s}, 1 \mathrm{H}), 7.43(\mathrm{~s}, 1 \mathrm{H}), 7.18(\mathrm{~d}, J=8.5$ 
$\mathrm{Hz}, 1 \mathrm{H}), 6.94(\mathrm{~d}, J=8.5 \mathrm{~Hz}, 1 \mathrm{H}), 3.92(\mathrm{~s}, 3 \mathrm{H}), 3.74(\mathrm{~s}, 3 \mathrm{H}), 3.71(\mathrm{~s}, 3 \mathrm{H}), 3.19-3.08(\mathrm{~m}, 2 \mathrm{H})$, $3.07-3.01(\mathrm{~m}, 2 \mathrm{H}), 3.00-2.90(\mathrm{~m}, 2 \mathrm{H}), 2.59-2.43(\mathrm{~m}, 3 \mathrm{H}), 1.84-1.74(\mathrm{~m}, 2 \mathrm{H}), 1.66-1.62$ (m, 1H), $1.24-1.18(\mathrm{~m}, 1 \mathrm{H}), 0.87(\mathrm{t}, J=7.4 \mathrm{~Hz}, 3 \mathrm{H})$.

10-bromo mitragynine 6, was submitted to different coupling reactions to furnish analogs of C10 mitragynine. 10-phenyl mitragynine (SC21) was synthesized in 71\% yield using palladiumcatalyzed coupling reaction of bromide 6 with phenylboronic acid. SC21 was then treated with oxone ${ }^{\circledR}$ and aqueous $\mathrm{NaHCO}_{3}$ to furnish the corresponding $7 \mathrm{OH}$ derivative $\mathbf{S C 3 1}$ in $31 \%$ yield. The synthesis of 10-3'-furyl mitragynine (SC22) was accomplished by a similar palladiumcatalyzed reaction of bromide 6 with 3-furanylboronic acid. Treatment of SC22 with oxone® and aqueous $\mathrm{NaHCO}_{3}$ produced alcohol SC32. The methyl group at $\mathrm{C} 10$ position was introduced by DABAL-Me ${ }_{3}$. Palladium catalyzed coupling reaction of bromide 6 with DABAL-Me in $_{3}$ presence of XPhos afforded 10-methyl mitragynine (SC23) in 77\% isolated yield. Oxidation of SC23 using oxone ${ }^{\circledR}$ and aqueous $\mathrm{NaHCO}_{3}$ resulted in alcohol $\mathbf{S C 3 3}$.

Synthesis of C12 analogs: For the C12 derivatives, as shown in Figure 1D, mitragynine (1) was brominated directly in presence of NBS and $\mathrm{AcOH}$ to afford mainly 12 bromo mitragynine (7) in $47 \%$ yield. Synthesis of 12-phenyl mitragynine (SC72) was achieved in 67\% yield using palladium-catalyzed coupling reaction of bromide 7 with phenylboronic acid. Oxone® and aqueous $\mathrm{NaHCO}_{3}$ mediated hydroxylation of $\mathbf{S C 7 2}$ furnished the corresponding $7 \mathrm{OH}$ derivative SC82 in $41 \%$ yield. The synthesis of 12-3'furanyl mitragynine (SC71) was done by a similar palladium-catalyzed reaction of bromide 7 with 3-furanylboronic acid. SC71 on treatment with oxone ${ }^{\circledR}$ and aqueous $\mathrm{NaHCO}_{3}$ furnished alcohol SC81. The methyl group at $\mathrm{C} 12$ position was installed by coupling reaction of bromide 7 with DABAL-Me 3 in presence of XPhos to afford 12- 
methyl mitragynine (SC73) in 87\% isolated yield. Oxidation of SC73 using oxone ${ }^{\circledR}$ and aqueous $\mathrm{NaHCO}_{3}$ yielded alcohol SC83 in $55 \%$ yield.

\section{Synthesis of individual embodiments:}

methyl(E)-2-((2S,3S,12bS)-3-ethyl-8-(((trifluoromethyl)sulfonyl)oxy)-1,2,3,4,6,7,12,12b-

octahydroindolo[2,3-a]quinolizin-2-yl)-3-methoxyacrylate(4):N-Phenyl-bis(trifluoromethane

sulfonimide) (66.4 mg, $0.18 \mathrm{mmol})$ was added to a solution of 9-hydroxymitragynine (65 mg, 0.16 $\mathrm{mmol})$ dissolved in DCM (3 mL) under argon at $\mathrm{RT}$. $\mathrm{Et}_{3} \mathrm{~N}(0.07 \mathrm{~mL}, 0.50 \mathrm{mmol})$ was added to the mixture and the reaction was continued overnight. MS indicated the completion of the reaction. Then, the solvent was evaporated and the reaction mixture was diluted in EtOAc $(20 \mathrm{~mL})$ and was washed with brine $(5 \times 20 \mathrm{~mL})$, dried over anhydrous $\mathrm{Na}_{2} \mathrm{SO}_{4}$ and filtered. The solvent was removed and residue was purified by flash column chromatography using 20-60\%EtOAc in hexane to get the desired triflate 4 as a white solid $53 \mathrm{mg}$; (Yield, 61\%). Since this is an intermediate compound, we recorded only proton NMR. ${ }^{1} \mathrm{H}$ NMR $(400 \mathrm{MHz}$, Chloroform- $d) \delta 8.01(\mathrm{~s}, 1 \mathrm{H}), 7.44(\mathrm{~d}, J=$ $0.8 \mathrm{~Hz}, 1 \mathrm{H}), 7.28(\mathrm{dt}, J=8.0,0.8 \mathrm{~Hz}, 1 \mathrm{H}), 7.07(\mathrm{dd}, J=8.5,7.6 \mathrm{~Hz}, 1 \mathrm{H}), 6.98(\mathrm{~d}, J=7.9 \mathrm{~Hz}, 1 \mathrm{H})$, $3.74(\mathrm{~s}, 3 \mathrm{H}), 3.71(\mathrm{~s}, 3 \mathrm{H}), 3.23-3.10(\mathrm{~m}, 2 \mathrm{H}), 3.02(\mathrm{tt}, J=17.0,4.9 \mathrm{~Hz}, 3 \mathrm{H}), 2.91(\mathrm{dd}, J=15.4$, $3.6 \mathrm{~Hz}, 1 \mathrm{H}), 2.62-2.51(\mathrm{~m}, 2 \mathrm{H}), 2.47(\mathrm{dd}, J=11.7,3.1 \mathrm{~Hz}, 1 \mathrm{H}), 1.85-1.69(\mathrm{~m}, 2 \mathrm{H}), 1.69-1.60$ (m, 1H), $1.25-1.16(\mathrm{~m}, 1 \mathrm{H}), 0.87(\mathrm{t}, J=7.3 \mathrm{~Hz}, 3 \mathrm{H})$. HRMS (ESI-TOF) $m / z:[\mathrm{M}+\mathrm{H}]^{+}$Calcd for $\mathrm{C}_{23} \mathrm{H}_{28} \mathrm{~F}_{3} \mathrm{~N}_{2} \mathrm{O}_{6} \mathrm{~S}$ 517.1620; found 517.1611.

methyl(E)-2-((2S,3S,12bS)-11-bromo-3-ethyl-8-methoxy-1,2,3,4,6,7,12,12b-octahydroindolo[2,3a]quinolizin-2-yl)-3-methoxyacrylate (7): Mitragynine (800 mg, $2.007 \mathrm{mmol}$ ) was dissolved in glacial acetic acid $(8 \mathrm{~mL})$. Then, NBS $(535.78 \mathrm{mg}, 3.01 \mathrm{mmol}, 1.5 \mathrm{eq})$ was added to the mixture under Argon. The mixture was stirred for $4 \mathrm{~h}$ at RT. MS indicated the formation of 
bromomitragynine. The reaction mixture was basified with sat. aq. $\mathrm{NaHCO}_{3}$ solution and the product was extracted with DCM (3x $20 \mathrm{~mL})$. The DCM layer was washed with brine $(15 \mathrm{~mL})$, dried over anhydrous $\mathrm{Na}_{2} \mathrm{SO}_{4}$ and filtered. The solvent was removed under reduced pressure and the crude product was purified by flash column chromatography using 10-25\% EtOAc in hexanes. Fraction 3-18 gave $450 \mathrm{mg}$ (47\%) of 12-bromomitragynine (7) while Fr 23-38 contained 10bromomitragynine ( $\sim 5 \%$; with minor impurities). Since compound 7 is an intermediate compound, we recorded only proton NMR. ${ }^{1} \mathrm{H}$ NMR (400 MHz, Chloroform- $d$ ) $\delta 7.84-7.73(\mathrm{~m}, 1 \mathrm{H}), 7.44$ (s, 1H), $7.10(\mathrm{~d}, J=8.3 \mathrm{~Hz}, 1 \mathrm{H}), 6.36(\mathrm{~d}, J=8.3 \mathrm{~Hz}, 1 \mathrm{H}), 3.85(\mathrm{~s}, 3 \mathrm{H}), 3.75(\mathrm{~s}, 3 \mathrm{H}), 3.71(\mathrm{~s}, 3 \mathrm{H})$, $3.17(\mathrm{~d}, J=11.6 \mathrm{~Hz}, 1 \mathrm{H}), 3.12-2.99(\mathrm{~m}, 3 \mathrm{H}), 2.97-2.87(\mathrm{~m}, 2 \mathrm{H}), 2.57-2.42(\mathrm{~m}, 3 \mathrm{H}), 1.85(\mathrm{dt}$, $J=12.8,3.1 \mathrm{~Hz}, 1 \mathrm{H}), 1.81-1.73(\mathrm{~m}, 1 \mathrm{H}), 1.66(\mathrm{~d}, J=19.9 \mathrm{~Hz}, 1 \mathrm{H}), 1.25-1.19(\mathrm{~m}, 1 \mathrm{H}), 0.87(\mathrm{t}$, $J=7.3 \mathrm{~Hz}, 3 \mathrm{H}$ ). HRMS (ESI-TOF) $m / z:[\mathrm{M}+\mathrm{H}]^{+}$Calcd for $\mathrm{C}_{23} \mathrm{H}_{30} \mathrm{BrN}_{2} \mathrm{O}_{6}$ 477.1383; found 477.1380.

methyl(E)-2-((2S,3S,12bS)-3-ethyl-8-(furan-3-yl)-1,2,3,4,6,7,12,12b-octahydroindolo[2,3a]quinolizin-2-yl)-3-methoxyacrylate (SC1): 4 (77.5 $\mathrm{mg}, 0.15 \mathrm{mmol})$ was dissolved in dry toluene $(0.5 \mathrm{~mL})$ and the solvent was removed under reduced pressure to ensure azeotropic removal of water residues. Dry methanol $(1 \mathrm{~mL})$ and dry toluene $(1.5 \mathrm{~mL})$ were added. To the resulting solution were added 3-furanylboronic acid ( $17.9 \mathrm{mg}, 0.16 \mathrm{mmol}, 1.1$ equiv), $\mathrm{K}_{2} \mathrm{CO}_{3}$ (41.5 mg, 2 equiv) and $\mathrm{Pd}\left(\mathrm{PPh}_{3}\right)_{4}\left(8.7 \mathrm{mg}, 0.05\right.$ equiv). The mixture was stirred at $80{ }^{\circ} \mathrm{C}$ for $8 \mathrm{hrs}$. The solvent was evaporated under reduced pressure and the residue was extracted with DCM $(3 \times 20 \mathrm{~mL})$. The combined extracts were washed with brine $(3 \times 1 / 3$ vol. $)$, dried $\left(\mathrm{Na}_{2} \mathrm{SO}_{4}\right)$ and concentrated to provide the crude product. The crude product was purified by flash column chromatography (gradient: $25-70 \%$ EtOAc in hexanes) to yield $47.6 \mathrm{mg}$ (73\%) of SC1 as a yellow amorphous solid. 
${ }^{1} \mathrm{H}$ NMR (400 MHz, Chloroform- $\left.d\right) \delta 7.81(\mathrm{~s}, 1 \mathrm{H}), 7.55-7.50(\mathrm{~m}, 1 \mathrm{H}), 7.47(\mathrm{~d}, J=1.0 \mathrm{~Hz}, 1 \mathrm{H})$, $7.44(\mathrm{~d}, J=0.9 \mathrm{~Hz}, 1 \mathrm{H}), 7.30-7.27(\mathrm{~m}, 1 \mathrm{H}), 7.11(\mathrm{dd}, J=8.1,7.2 \mathrm{~Hz}, 1 \mathrm{H}), 7.00-6.96(\mathrm{~m}, 1 \mathrm{H})$, $6.62-6.58(\mathrm{~m}, 1 \mathrm{H}), 3.74(\mathrm{~s}, 3 \mathrm{H}), 3.71(\mathrm{~s}, 3 \mathrm{H}), 3.17(\mathrm{~d}, J=11.3 \mathrm{~Hz}, 1 \mathrm{H}), 3.02(\mathrm{ddd}, J=20.5,11.0$, $2.9 \mathrm{~Hz}, 2 \mathrm{H}), 2.91-2.80(\mathrm{~m}, 2 \mathrm{H}), 2.55(\mathrm{q}, J=12.5 \mathrm{~Hz}, 1 \mathrm{H}), 2.46-2.36(\mathrm{~m}, 3 \mathrm{H}), 1.84(\mathrm{~d}, J=13.4$ $\mathrm{Hz}, 1 \mathrm{H}), 1.78(\mathrm{dt}, J=13.3,5.8 \mathrm{~Hz}, 1 \mathrm{H}), 1.63(\mathrm{~d}, J=11.4 \mathrm{~Hz}, 1 \mathrm{H}), 1.25-1.19(\mathrm{~m}, 1 \mathrm{H}), 0.86(\mathrm{t}, J$ $=7.3 \mathrm{~Hz}, 3 \mathrm{H}) .{ }^{13} \mathrm{C}$ NMR $(125 \mathrm{MHz}$, Chloroform- $d) \delta 169.40,160.75,142.12,140.18,136.49$, $136.30,125.82,125.76,125.38,121.33,121.17,113.22,111.70,110.25,108.36,61.77,61.72$, 58.00, 53.94, 51.57, 40.84, 40.17, 30.21, 24.92, 19.36, 13.03. HRMS (ESI-TOF) $m / z:[\mathrm{M}+\mathrm{H}]^{+}$ Calcd for $\mathrm{C}_{26} \mathrm{H}_{31} \mathrm{~N}_{2} \mathrm{O}_{4} 435.2278$; found 435.2273.

methyl(E)-2-((2S,3S,12bS)-3-ethyl-8-phenyl-1,2,3,4,6,7,12,12b-octahydroindolo[2,3-

a]quinolizin-2-yl)-3-methoxyacrylate (SC 3): 4 (77.5 mg, $0.15 \mathrm{mmol}$ ) was dissolved in dry toluene $(0.5 \mathrm{~mL})$ and the solvent was removed under reduced pressure to ensure azeotropic removal of water residues. Dry methanol $(1 \mathrm{~mL})$ and dry toluene $(1.5 \mathrm{~mL})$ were added. To the resulting solution were added phenylboronic acid (19.5 mg, $0.16 \mathrm{mmol}, 1.1$ equiv), $\mathrm{K}_{2} \mathrm{CO}_{3}$ (41.5 mg, 2 equiv) and $\mathrm{Pd}\left(\mathrm{PPh}_{3}\right)_{4}\left(8.7 \mathrm{mg}, 0.05\right.$ equiv). The mixture was stirred at $80{ }^{\circ} \mathrm{C}$ for $8 \mathrm{hrs}$. The solvent was evaporated under reduced pressure and the residue was extracted with DCM $(3 \times 20 \mathrm{~mL})$. The combined extracts were washed with brine $(3 \times 1 / 3$ vol. $)$, dried $\left(\mathrm{Na}_{2} \mathrm{SO}_{4}\right)$ and concentrated to provide the crude product. The crude product was purified by flash column chromatography (gradient: $25-70 \%$ EtOAc in hexanes) to yield $43.3 \mathrm{mg}(65 \%)$ of SC3 as a light yellow amorphous solid. ${ }^{1} \mathrm{H}$ NMR (400 MHz, Chloroform- $d$ ) $\delta 7.83(\mathrm{~s}, 1 \mathrm{H}), 7.50-7.33(\mathrm{~m}, 6 \mathrm{H}), 7.30$ (d, J = 8.0 Hz, 1H), $7.15(\mathrm{t}, J=7.7 \mathrm{~Hz}, 1 \mathrm{H}), 6.98(\mathrm{~d}, J=7.2 \mathrm{~Hz}, 1 \mathrm{H}), 3.74(\mathrm{~s}, 3 \mathrm{H}), 3.71(\mathrm{~s}, 3 \mathrm{H}), 3.17(\mathrm{~d}, J=11.3$ $\mathrm{Hz}, 1 \mathrm{H}), 3.04(\mathrm{dt}, J=13.1,3.7 \mathrm{~Hz}, 1 \mathrm{H}), 2.97(\mathrm{dd}, J=11.7,2.2 \mathrm{~Hz}, 1 \mathrm{H}), 2.78-2.73(\mathrm{~m}, 1 \mathrm{H}), 2.71$ 
$-2.64(\mathrm{~m}, 1 \mathrm{H}), 2.55(\mathrm{q}, J=12.6 \mathrm{~Hz}, 1 \mathrm{H}), 2.41(\mathrm{dd}, J=11.3,3.1 \mathrm{~Hz}, 1 \mathrm{H}), 2.33(\mathrm{td}, J=10.7,10.2$,

4.1 Hz, 1H), $2.01-1.94(\mathrm{~m}, 1 \mathrm{H}), 1.85(\mathrm{~d}, J=12.9 \mathrm{~Hz}, 1 \mathrm{H}), 1.81-1.71(\mathrm{~m}, 2 \mathrm{H}), 1.22(\mathrm{~d}, J=8.0$

$\mathrm{Hz}, 1 \mathrm{H}), 0.85$ (t, $J=7.3 \mathrm{~Hz}, 3 \mathrm{H}) .{ }^{13} \mathrm{C}$ NMR $(100 \mathrm{MHz}$, Chloroform-d) $\delta 169.18,160.54,141.67$,

$136.19,136.06,134.96,129.77,127.44,126.59,125.24,121.00,120.86,111.46,109.76,108.17$,

$61.58,61.52,57.74,53.69,51.37,40.60,39.93,30.00,24.68,19.15,12.83$. HRMS (ESI-TOF) $m / z$ :

$[\mathrm{M}+\mathrm{H}]^{+}$Calcd for $\mathrm{C}_{28} \mathrm{H}_{33} \mathrm{~N}_{2} \mathrm{O}_{3}$ 445.2486; found 445.2484.

methyl(E)-2-((2S,3S,12bS)-3-ethyl-8-methyl-1,2,3,4,6,7,12,12b-octahydroindolo[2,3-

a]quinolizin-2-yl)-3-methoxyacrylate (SC4): Starting material 4 (77.5 mg, $0.15 \mathrm{mmol}), \mathrm{Pd}_{2}(\mathrm{dba})_{3}$

(13.7 mg, 0.1 equiv), Xphos (10.7 mg, 0.15 equiv) and DABAL- Me3 (153.8 mg, 4 equiv) were balanced into an oven dried vial. Vial was purged with argon and dry THF (3 mL) was added under argon. Vial was sealed with a Teflon lined screw cap and heated to $60{ }^{\circ} \mathrm{C}$. After stirring for $8 \mathrm{~h}$ complete conversion was observed by LC-MS. The reaction mixture was cooled to RT and concentrated in vacuo. The product was purified by flash column chromatography (gradient: 25 $75 \%$ EtOAc in hexanes); to yield $39 \mathrm{mg}(68 \%)$ of $\mathbf{S C 4}$ as a yellow solid. ${ }^{1} \mathrm{H}$ NMR (400 MHz, Chloroform- $d) \delta 7.73(\mathrm{~s}, 1 \mathrm{H}), 7.43(\mathrm{~s}, 1 \mathrm{H}), 7.10(\mathrm{~d}, J=8.1 \mathrm{~Hz}, 1 \mathrm{H}), 6.97(\mathrm{t}, J=7.6 \mathrm{~Hz}, 1 \mathrm{H}), 6.78$ $(\mathrm{d}, J=6.6 \mathrm{~Hz}, 1 \mathrm{H}), 3.72(\mathrm{~s}, 3 \mathrm{H}), 3.71(\mathrm{~s}, 3 \mathrm{H}), 3.29-3.14(\mathrm{~m}, 2 \mathrm{H}), 3.08-2.93(\mathrm{~m}, 4 \mathrm{H}), 2.62(\mathrm{~s}$, $3 \mathrm{H}), 2.59-2.43(\mathrm{~m}, 3 \mathrm{H}), 1.84-1.74(\mathrm{~m}, 2 \mathrm{H}), 1.64(\mathrm{dd}, J=8.7,5.4 \mathrm{~Hz}, 1 \mathrm{H}), 1.27-1.17(\mathrm{~m}, 1 \mathrm{H})$, $0.87(\mathrm{t}, J=7.3 \mathrm{~Hz}, 3 \mathrm{H}) .{ }^{13} \mathrm{C}$ NMR (100 MHz, Chloroform- $\left.d\right) \delta 169.22,160.57,135.85,134.92$, $130.35,126.50,121.23,120.38,111.43,108.44,108.30,61.55,61.34,57.70,53.76,51.37,40.60$ 39.85, 29.89, 24.43, 19.56, 19.10, 12.85. HRMS (ESI-TOF) $m / z:[\mathrm{M}+\mathrm{H}]^{+}$Calcd for $\mathrm{C}_{23} \mathrm{H}_{31} \mathrm{~N}_{2} \mathrm{O}_{3}$ 383.2329; found 383.2327. 
methyl(E)-2-((2S,3S,7aS,12bS)-3-ethyl-7a-hydroxy-8-phenyl-1,2,3,4,6,7,7a,12b-

octahydroindolo[2,3-a]quinolizin-2-yl)-3-methoxyacrylate (SC11): A saturated aq. $\mathrm{NaHCO}_{3}$ (3 $\mathrm{mL})$ was added to a solution of $\mathbf{S C 3}(44.4 \mathrm{mg}, 0.10 \mathrm{mmol})$ in acetone $(4 \mathrm{~mL})$ at $0{ }^{\circ} \mathrm{C}$ resulting in suspension formation. A solution of oxone ${ }^{\circledR}(30.6 \mathrm{mg}, 0.20 \mathrm{mmol})$ in distilled water $(1 \mathrm{~mL}) \mathrm{was}$ added dropwise over 5 min period (this is crucial for the reaction! slower addition is better). The reaction mixture was stirred for additional $30 \mathrm{~min}$ at $0{ }^{\circ} \mathrm{C}$. Then, the content was diluted with water (2-3 mL) and the product was extracted in ethyl acetate $(3 \times 10 \mathrm{~mL})$. EtOAc layer was washed with brine $(15 \mathrm{~mL})$, dried over anhydrous $\mathrm{Na}_{2} \mathrm{SO}_{4}$, and filtered. Solvent was removed under reduced pressure and the content was purified by flash column chromatography (gradient: $25-65 \%$ EtOAc in hexanes); to yield $15.2 \mathrm{mg}(33 \%)$ of $\mathbf{S C 1 1}$ as a white solid. ${ }^{1} \mathrm{H}$ NMR (500 MHz, Chloroformd) $\delta 7.59-7.51(\mathrm{~m}, 3 \mathrm{H}), 7.46-7.41(\mathrm{~m}, 3 \mathrm{H}), 7.41-7.35(\mathrm{~m}, 2 \mathrm{H}), 7.13(\mathrm{dd}, J=7.8,0.9 \mathrm{~Hz}, 1 \mathrm{H})$, $3.81(\mathrm{~s}, 3 \mathrm{H}), 3.69(\mathrm{~s}, 3 \mathrm{H}), 3.09(\mathrm{dd}, J=11.1,2.6 \mathrm{~Hz}, 1 \mathrm{H}), 3.04-2.95(\mathrm{~m}, 2 \mathrm{H}), 2.81(\mathrm{td}, J=13.6$, $11.0 \mathrm{~Hz}, 1 \mathrm{H}), 2.64-2.56(\mathrm{~m}, 1 \mathrm{H}), 2.46(\mathrm{ddd}, J=11.9,4.7,2.3 \mathrm{~Hz}, 1 \mathrm{H}), 2.41(\mathrm{dd}, J=11.4,3.0$ $\mathrm{Hz}, 1 \mathrm{H}), 2.05(\mathrm{~d}, J=1.5 \mathrm{~Hz}, 1 \mathrm{H}), 1.94(\mathrm{ddt}, J=30.4,13.8,2.7 \mathrm{~Hz}, 2 \mathrm{H}), 1.67(\mathrm{ddd}, J=13.5,11.2$, $7.0 \mathrm{~Hz}, 1 \mathrm{H}), 1.57(\mathrm{~d}, J=11.2 \mathrm{~Hz}, 1 \mathrm{H}), 1.49(\mathrm{td}, J=13.3,4.1 \mathrm{~Hz}, 1 \mathrm{H}), 1.28-1.19(\mathrm{~m}, 1 \mathrm{H}), 0.79$ $(\mathrm{t}, J=7.3 \mathrm{~Hz}, 3 \mathrm{H}) .{ }^{13} \mathrm{C}$ NMR $(100 \mathrm{MHz}$, Chloroform- $d) \delta 183.99,169.30,160.76,154.17,139.44$, $139.33,137.29,129.61,129.33,128.11,127.61,127.57,120.36,111.24,80.98,61.80,61.48$, 58.15, 51.32, 50.07, 40.47, 39.21, 34.85, 26.07, 18.93, 12.78. HRMS (ESI-TOF) $m / z:[\mathrm{M}+\mathrm{H}]^{+}$ Calcd for $\mathrm{C}_{28} \mathrm{H}_{33} \mathrm{~N}_{2} \mathrm{O}_{4} 461.2435$; found 461.2431.

methyl(E)-2-((2S,3S,7aS,12bS)-3-ethyl-7a-hydroxy-8-methyl-1,2,3,4,6,7,7a,12boctahydroindolo[2,3-a]quinolizin-2-yl)-3-methoxyacrylate (SC12): A saturated aq. $\mathrm{NaHCO}_{3}(3$ $\mathrm{mL})$ was added to a solution of $\mathbf{S C 4}(38.2 \mathrm{mg}, 0.10 \mathrm{mmol})$ in acetone $(4 \mathrm{~mL})$ at $0{ }^{\circ} \mathrm{C}$ resulting in 
suspension formation. A solution of oxone ${ }^{\circledR}(30.6 \mathrm{mg}, 0.20 \mathrm{mmol})$ in distilled water $(1 \mathrm{~mL})$ was added dropwise over $5 \mathrm{~min}$ period. The reaction mixture was stirred for additional $30 \mathrm{~min}$ at $0{ }^{\circ} \mathrm{C}$. Then, the content was diluted with water $(2-3 \mathrm{~mL})$ and the product was extracted in ethyl acetate $(3 \times 10 \mathrm{~mL})$. EtOAc layer was washed with brine $(15 \mathrm{~mL})$, dried over anhydrous $\mathrm{Na}_{2} \mathrm{SO}_{4}$, and filtered. Solvent was removed under reduced pressure and the content was purified by flash column chromatography (gradient: 25-65\% EtOAc in hexanes); to yield $16.7 \mathrm{mg}$ (42\%) of SC12 as a white solid. ${ }^{1} \mathrm{H}$ NMR (400 MHz, Chloroform- $\left.d\right) \delta 7.44(\mathrm{~s}, 1 \mathrm{H}), 7.38(\mathrm{~d}, J=7.6 \mathrm{~Hz}, 1 \mathrm{H}), 7.21(\mathrm{t}, J=7.6$ Hz, 1H), 6.95 (d, J=7.7 Hz, 1H), $3.81(\mathrm{~s}, 3 \mathrm{H}), 3.67$ (s, 3H), $3.13(\mathrm{dd}, J=10.7,2.4 \mathrm{~Hz}, 1 \mathrm{H}), 3.08$ $-2.97(\mathrm{~m}, 2 \mathrm{H}), 2.80(\mathrm{ddd}, J=21.6,12.8,10.0 \mathrm{~Hz}, 2 \mathrm{H}), 2.68-2.59(\mathrm{~m}, 2 \mathrm{H}), 2.48(\mathrm{~d}, J=11.6 \mathrm{~Hz}$, 1H), $2.45(\mathrm{~s}, 3 \mathrm{H}), 2.09-2.07(\mathrm{~m}, 1 \mathrm{H}), 1.86(\mathrm{~d}, J=13.2 \mathrm{~Hz}, 1 \mathrm{H}), 1.68-1.55(\mathrm{~m}, 3 \mathrm{H}), 1.21(\mathrm{dd}, J$ $=7.2,5.6 \mathrm{~Hz}, 1 \mathrm{H}), 0.82(\mathrm{t}, J=7.3 \mathrm{~Hz}, 3 \mathrm{H}) .{ }^{13} \mathrm{C} \mathrm{NMR}(100 \mathrm{MHz}$, Chloroform- $d) \delta 184.01,169.32$, $160.78,153.58,138.01,134.44,129.39,127.89,118.78,111.20,81.30,61.81,61.44,58.16,51.30$, 50.11, 40.51, 39.32, 34.94, 26.06, 18.95, 17.11, 12.82. HRMS (ESI-TOF) $m / z:[\mathrm{M}+\mathrm{H}]^{+}$Calcd for $\mathrm{C}_{23} \mathrm{H}_{31} \mathrm{~N}_{2} \mathrm{O}_{4}$ 399.227; found 399.2277.

methyl(E)-2-((2S,3S,7aS,12bS)-3-ethyl-8-(furan-3-yl)-7a-hydroxy-1,2,3,4,6,7,7a,12boctahydroindolo[2,3-a]quinolizin-2-yl)-3-methoxyacrylate (SC13): A saturated aq. $\mathrm{NaHCO}_{3}(3$ $\mathrm{mL}$ ) was added to a solution of $\mathbf{S C 1}(43.4 \mathrm{mg}, 0.10 \mathrm{mmol})$ in acetone $(4 \mathrm{~mL})$ at $0{ }^{\circ} \mathrm{C}$ resulting in suspension formation. A solution of oxone ${ }^{\circledR}(30.6 \mathrm{mg}, 0.20 \mathrm{mmol})$ in distilled water $(1 \mathrm{~mL}) \mathrm{was}$ added dropwise over 5 min period. The reaction mixture was stirred for additional $30 \mathrm{~min}$ at $0{ }^{\circ} \mathrm{C}$. Then, the content was diluted with water $(2-3 \mathrm{~mL})$ and the product was extracted in ethyl acetate $(3 \times 10 \mathrm{~mL})$. EtOAc layer was washed with brine $(15 \mathrm{~mL})$, dried over anhydrous $\mathrm{Na}_{2} \mathrm{SO}_{4}$, and filtered. Solvent was removed under reduced pressure and the content was purified by flash column 
chromatography (gradient: 25-65\% EtOAc in hexanes); to yield $17.1 \mathrm{mg}(38 \%)$ of SC13 as a white solid. ${ }^{1} \mathrm{H}$ NMR (500 MHz, Chloroform- $\left.d\right) \delta 8.05(\mathrm{dd}, J=1.6,0.9 \mathrm{~Hz}, 1 \mathrm{H}), 7.50-7.48(\mathrm{~m}, 2 \mathrm{H})$, $7.44(\mathrm{~s}, 1 \mathrm{H}), 7.34(\mathrm{t}, J=7.7 \mathrm{~Hz}, 1 \mathrm{H}), 7.24(\mathrm{dd}, J=7.8,1.0 \mathrm{~Hz}, 1 \mathrm{H}), 6.87(\mathrm{dd}, J=1.9,0.9 \mathrm{~Hz}, 1 \mathrm{H})$, $3.82(\mathrm{~s}, 3 \mathrm{H}), 3.68(\mathrm{~s}, 3 \mathrm{H}), 3.14(\mathrm{dd}, J=11.0,2.5 \mathrm{~Hz}, 1 \mathrm{H}), 3.06-2.99(\mathrm{~m}, 2 \mathrm{H}), 2.88-2.71(\mathrm{~m}$, 2H), $2.62-2.55(\mathrm{~m}, 2 \mathrm{H}), 2.46(\mathrm{dd}, J=11.4,3.1 \mathrm{~Hz}, 1 \mathrm{H}), 2.22(\mathrm{~s}, 1 \mathrm{H}), 1.90(\mathrm{dd}, J=13.6,3.2 \mathrm{~Hz}$, 1H), 1.68 (ddt, $J=14.1,11.8,7.1 \mathrm{~Hz}, 2 \mathrm{H}), 1.45(\mathrm{td}, J=13.5,12.8,4.7 \mathrm{~Hz}, 1 \mathrm{H}), 1.26-1.19(\mathrm{~m}$, 1H), $0.81(\mathrm{t}, J=7.3 \mathrm{~Hz}, 3 \mathrm{H}) .{ }^{13} \mathrm{C}$ NMR (100 MHz, Chloroform- $\left.d\right) \delta$ 184.10, 169.31, 160.80, $154.40,142.99,141.72,136.55,129.85,129.63,126.11,123.43,120.12,111.19,111.12,81.19$, 61.81, 61.40, 58.14, 51.31, 50.05, 40.48, 39.30, 32.67, 26.09, 18.95, 12.81. HRMS (ESI-TOF) $m / z$ : $[\mathrm{M}+\mathrm{H}]^{+}$Calcd for $\mathrm{C}_{26} \mathrm{H}_{31} \mathrm{~N}_{2} \mathrm{O}_{5} 451.2227$; found 451.2224.

methyl(E)-2-((2S,3S,12bS)-3-ethyl-8-methoxy-9-phenyl-1,2,3,4,6,7,12,12b-octahydroindolo[2,3a]quinolizin-2-yl)-3-methoxyacrylate (SC21): Starting material 6 (71.6 mg, $0.15 \mathrm{mmol}$ ), phenylboronic acid (40.2 mg, 2.2 equiv), KOAc (33.8 mg, 2.3 equiv) and $\mathrm{Pd}(\mathrm{dppf}) \mathrm{Cl}_{2} \cdot \mathrm{CH}_{2} \mathrm{Cl}_{2}(6.1$ mg, 0.05 equiv) were balanced into an oven-dried vial. Vial was purged with argon and dry THF (3 mL) was added under a stream of argon. Vial was closed with a Teflon lined solid screw cap and heated to $70{ }^{\circ} \mathrm{C}$. After $6 \mathrm{~h}$ LC-MS and TLC indicated full consumption of starting material. The solvent was evaporated under reduced pressure and the residue was extracted with DCM $(3 \times 20 \mathrm{~mL})$. The combined extracts were washed with brine $(3 \times 1 / 3$ vol. $)$, dried $\left(\mathrm{Na}_{2} \mathrm{SO}_{4}\right)$ and concentrated to provide the crude product. The crude product was purified by flash column chromatography (gradient: $25-70 \%$ EtOAc in hexanes) to yield $50.5 \mathrm{mg}$ (71\%) of SC21 as a yellow amorphous solid. ${ }^{1} \mathrm{H}$ NMR (400 MHz, Chloroform- $\left.d\right) \delta 7.77$ (s, 1H), $7.65-7.58$ (m, 2H), $7.41(\mathrm{dd}, J=15.3,7.8 \mathrm{~Hz}, 3 \mathrm{H}), 7.30(\mathrm{~d}, J=7.5 \mathrm{~Hz}, 1 \mathrm{H}), 7.14-7.06(\mathrm{~m}, 2 \mathrm{H}), 3.74(\mathrm{~s}, 3 \mathrm{H}), 3.72$ 
$(\mathrm{s}, 3 \mathrm{H}), 3.51(\mathrm{~s}, 3 \mathrm{H}), 3.19(\mathrm{~d}, J=11.9 \mathrm{~Hz}, 2 \mathrm{H}), 3.09-2.93(\mathrm{~m}, 4 \mathrm{H}), 2.63-2.45(\mathrm{~m}, 3 \mathrm{H}), 1.87-$ $1.75(\mathrm{~m}, 2 \mathrm{H}), 1.64(\mathrm{~d}, J=11.4 \mathrm{~Hz}, 1 \mathrm{H}), 1.25-1.17(\mathrm{~m}, 1 \mathrm{H}), 0.88(\mathrm{t}, J=7.3 \mathrm{~Hz}, 3 \mathrm{H}) .{ }^{13} \mathrm{C} \mathrm{NMR}$ $(100 \mathrm{MHz}$, Chloroform- $d) \delta 169.18,160.53,151.01,139.65,137.39,135.53,129.55,128.05$, $126.13,125.13,124.33,121.50,111.49,107.48,107.06,61.65,61.57,61.32,57.81,53.75,51.37$, 40.67, 39.92, 29.92, 23.57, 19.14, 12.88. HRMS (ESI-TOF) $m / z:[\mathrm{M}+\mathrm{H}]^{+}$Calcd for $\mathrm{C}_{29} \mathrm{H}_{35} \mathrm{~N}_{2} \mathrm{O}_{4}$ 475.2591; found 475.2586.

methyl(E)-2-((2S,3S,12bS)-3-ethyl-9-(furan-3-yl)-8-methoxy-1,2,3,4,6,7,12,12boctahydroindolo[2,3-a]quinolizin-2-yl)-3-methoxyacrylate (SC22): Starting material 6 (71.6 mg, $0.15 \mathrm{mmol}$ ), 3-furanylboronic acid (36.9 mg, 2.2 equiv), KOAc (33.8 mg, 2.3 equiv) and $\mathrm{Pd}(\mathrm{dppf}) \mathrm{Cl}_{2} \cdot \mathrm{CH}_{2} \mathrm{Cl}_{2}(6.1 \mathrm{mg}, 0.05$ equiv $)$ were balanced into an oven-dried vial. Vial was purged with argon and dry THF (3 mL) was added under a stream of argon. Vial was closed with a Teflon lined solid screw cap and heated to $70{ }^{\circ} \mathrm{C}$. After $6 \mathrm{~h}$ LC-MS and TLC indicated full consumption of starting material. The solvent was evaporated under reduced pressure and the residue was extracted with DCM $(3 \times 20 \mathrm{~mL})$. The combined extracts were washed with brine $(3 \times 1 / 3$ vol. $)$, dried $\left(\mathrm{Na}_{2} \mathrm{SO}_{4}\right)$ and concentrated to provide the crude product. The crude product was purified by flash column chromatography (gradient: $25-70 \%$ EtOAc in hexanes) to yield $41.1 \mathrm{mg}(59 \%)$ of SC22 as a light yellow solid. ${ }^{1} \mathrm{H}$ NMR $(400 \mathrm{MHz}$, Chloroform- $d) \delta 7.76(\mathrm{~s}, 1 \mathrm{H}), 7.68(\mathrm{~s}, 1 \mathrm{H}), 7.56$ $-7.51(\mathrm{~m}, 1 \mathrm{H}), 7.43(\mathrm{~s}, 1 \mathrm{H}), 7.03(\mathrm{~d}, J=7.9 \mathrm{~Hz}, 1 \mathrm{H}), 6.71-6.67(\mathrm{~m}, 1 \mathrm{H}), 6.50(\mathrm{~d}, J=8.4 \mathrm{~Hz}$ $1 \mathrm{H}), 3.89(\mathrm{~s}, 3 \mathrm{H}), 3.73(\mathrm{~s}, 3 \mathrm{H}), 3.70(\mathrm{~s}, 3 \mathrm{H}), 3.19-2.90(\mathrm{~m}, 6 \mathrm{H}), 2.58-2.43(\mathrm{~m}, 3 \mathrm{H}), 1.82-1.74$ $(\mathrm{m}, 2 \mathrm{H}), 1.63($ br s, $1 \mathrm{H}), 1.23-1.16(\mathrm{~m}, 1 \mathrm{H}), 0.87(\mathrm{t}, J=7.3 \mathrm{~Hz}, 3 \mathrm{H}) .{ }^{13} \mathrm{C} \mathrm{NMR}(100 \mathrm{MHz}$, Chloroform- $d$ ) $\delta 169.18,160.56,154.05,143.49,138.21,134.97,133.97,123.82,121.18,117.80$, $111.44,110.33,109.48,108.79,100.22,61.57,61.36,57.79,55.43,53.70,51.35,40.75,39.84$ 
29.97, 23.87, 19.15, 12.88.. HRMS (ESI-TOF) $m / z$ : $[\mathrm{M}+\mathrm{H}]^{+}$Calcd for $\mathrm{C}_{27} \mathrm{H}_{33} \mathrm{~N}_{2} \mathrm{O}_{5} 465.2384$; found 465.2381.

methyl(E)-2-((2S,3S,12bS)-3-ethyl-8-methoxy-9-methyl-1,2,3,4,6,7,12,12b-octahydroindolo[2,3a]quinolizin-2-yl)-3-methoxyacrylate (SC23): Starting material 6 (71.6 mg, $0.15 \mathrm{mmol}), \mathrm{Pd}_{2}(\mathrm{dba})_{3}$ (13.7 mg, 0.1 equiv), Xphos (10.7 mg, 0.15 equiv) and DABAL- Me3 (153.8 mg, 4 equiv) were balanced into an oven dried vial. Vial was purged with argon and dry THF (3 mL) was added under argon. Vial was sealed with a Teflon lined screw cap and heated to $60{ }^{\circ} \mathrm{C}$. After stirring for $8 \mathrm{~h}$ complete conversion was observed by LC-MS. The reaction mixture was cooled to RT and concentrated in vacuo. The product was purified by flash column chromatography (gradient: 25 $75 \%$ EtOAc in hexanes); to yield $31.8 \mathrm{mg}(77 \%)$ of $\mathbf{S C 2 3}$ as a yellow solid. ${ }^{1} \mathrm{H}$ NMR (400 MHz, Chloroform- $d) \delta 7.68(\mathrm{~s}, 1 \mathrm{H}), 7.43(\mathrm{~s}, 1 \mathrm{H}), 6.97(\mathrm{~d}, J=10.3 \mathrm{~Hz}, 1 \mathrm{H}), 6.88(\mathrm{~d}, J=8.1 \mathrm{~Hz}, 1 \mathrm{H})$, $3.84(\mathrm{~s}, 3 \mathrm{H}), 3.73(\mathrm{~s}, 3 \mathrm{H}), 3.71(\mathrm{~s}, 3 \mathrm{H}), 3.16(\mathrm{~d}, J=10.8 \mathrm{~Hz}, 2 \mathrm{H}), 3.08-3.00(\mathrm{~m}, 2 \mathrm{H}), 2.95(\mathrm{~d}, J$ $=12.5 \mathrm{~Hz}, 2 \mathrm{H}), 2.58-2.43(\mathrm{~m}, 3 \mathrm{H}), 2.34(\mathrm{~s}, 3 \mathrm{H}), 1.82-1.75(\mathrm{~m}, 2 \mathrm{H}), 1.63(\mathrm{~d}, J=11.8 \mathrm{~Hz}, 1 \mathrm{H})$, $1.23-1,19(\mathrm{~m}, 1 \mathrm{H}), 0.88(\mathrm{t}, J=7.2 \mathrm{~Hz}, 3 \mathrm{H}) .{ }^{13} \mathrm{C}$ NMR $(100 \mathrm{MHz}$, Chloroform- $d) \delta 169.21,160.54$, $151.43,136.58,135.03,124.29,121.29,119.95,111.46,106.80,106.47,61.74,61.57,61.40$, 57.82, 53.80, 51.36, 40.64, 39.94, 29.85, 23.46, 19.14, 15.10, 12.88. HRMS (ESI-TOF) $m / z$ : $[\mathrm{M}+\mathrm{H}]^{+}$Calcd for $\mathrm{C}_{24} \mathrm{H}_{33} \mathrm{~N}_{2} \mathrm{O}_{4} 413.2435$; found 413.2433.

methyl(E)-2-((2S,3S,7aS,12bS)-3-ethyl-7a-hydroxy-8-methoxy-9-phenyl-1,2,3,4,6,7,7a,12boctahydroindolo[2,3-a]quinolizin-2-yl)-3-methoxyacrylate (SC31): A saturated aq. $\mathrm{NaHCO}_{3}(3$ $\mathrm{mL})$ was added to a solution of $\mathbf{S C 2 1}(47.4 \mathrm{mg}, 0.10 \mathrm{mmol})$ in acetone $(4 \mathrm{~mL})$ at $0{ }^{\circ} \mathrm{C}$ resulting in suspension formation. A solution of oxone ${ }^{\circledR}(30.6 \mathrm{mg}, 0.20 \mathrm{mmol})$ in distilled water $(1 \mathrm{~mL})$ was added dropwise over 5 min period. The reaction mixture was stirred for additional $30 \mathrm{~min}$ at $0{ }^{\circ} \mathrm{C}$. Then, the content was diluted with water $(2-3 \mathrm{~mL})$ and the product was extracted in ethyl acetate 
(3x10 mL). EtOAc layer was washed with brine $(15 \mathrm{~mL})$, dried over anhydrous $\mathrm{Na}_{2} \mathrm{SO}_{4}$, and filtered. Solvent was removed under reduced pressure and the content was purified by flash column chromatography (gradient: 25-65\% EtOAc in hexanes); to yield $15.1 \mathrm{mg}$ (31\%) of SC31 as a white solid. ${ }^{1} \mathrm{H}$ NMR (400 MHz, Chloroform-d) $\delta 7.60-7.54(\mathrm{~m}, 2 \mathrm{H}), 7.47-7.30(\mathrm{~m}, 6 \mathrm{H}), 3.82(\mathrm{~s}, 3 \mathrm{H})$, $3.70(\mathrm{~s}, 3 \mathrm{H}), 3.47(\mathrm{~s}, 3 \mathrm{H}), 3.18-3.12(\mathrm{~m}, 1 \mathrm{H}), 3.05(\mathrm{t}, J=13.0 \mathrm{~Hz}, 2 \mathrm{H}), 2.89-2.78(\mathrm{~m}, 2 \mathrm{H}), 2.66$ $(\mathrm{t}, J=14.2 \mathrm{~Hz}, 2 \mathrm{H}), 2.53-2.47(\mathrm{~m}, 1 \mathrm{H}), 2.30(\mathrm{~s}, 1 \mathrm{H}), 1.91(\mathrm{~d}, J=13.6 \mathrm{~Hz}, 1 \mathrm{H}), 1.86-1.67(\mathrm{~m}$, $3 \mathrm{H}), 1.25(\mathrm{~d}, J=5.5 \mathrm{~Hz}, 1 \mathrm{H}), 0.83(\mathrm{t}, J=7.3 \mathrm{~Hz}, 3 \mathrm{H}) .{ }^{13} \mathrm{C}$ NMR $(100 \mathrm{MHz}$, Chloroform- $d$ ) $\delta$ $184.21,169.30,160.75,154.66,154.25,138.06,132.92,132.81,132.36,128.93,128.42,127.23$, $117.27,111.28,81.10,61.81,61.60,61.43,58.21,51.31,50.13,40.55,39.28,36.35,26.10,18.97$, 12.83. HRMS (ESI-TOF) $m / z:[\mathrm{M}+\mathrm{H}]^{+}$Calcd for $\mathrm{C}_{29} \mathrm{H}_{35} \mathrm{~N}_{2} \mathrm{O}_{5} 491.2540$; found 491.2542.

methyl(E)-2-((2S,3S,7aS,12bS)-3-ethyl-9-(furan-3-yl)-7a-hydroxy-8-methoxy-1,2,3,4,6, 7,7a,12boctahydroindolo[2,3-a]quinolizin-2-yl)-3-methoxyacrylate (SC32): A saturated aq. $\mathrm{NaHCO}_{3}(3$ $\mathrm{mL})$ was added to a solution of $\mathbf{S C 2 2}(46.4 \mathrm{mg}, 0.10 \mathrm{mmol})$ in acetone $(4 \mathrm{~mL})$ at $0{ }^{\circ} \mathrm{C}$ resulting in suspension formation. A solution of oxone ${ }^{\circledR}(30.6 \mathrm{mg}, 0.20 \mathrm{mmol})$ in distilled water $(1 \mathrm{~mL})$ was added dropwise over 5 min period. The reaction mixture was stirred for additional $30 \mathrm{~min}$ at $0{ }^{\circ} \mathrm{C}$. Then, the content was diluted with water $(2-3 \mathrm{~mL})$ and the product was extracted in ethyl acetate (3x10 mL). EtOAc layer was washed with brine $(15 \mathrm{~mL})$, dried over anhydrous $\mathrm{Na}_{2} \mathrm{SO}_{4}$, and filtered. Solvent was removed under reduced pressure and the content was purified by flash column chromatography (gradient: $25-65 \%$ EtOAc in hexanes); to yield $16.8 \mathrm{mg}$ (35\%) of SC32 as a white solid. ${ }^{1} \mathrm{H}$ NMR (400 MHz, Chloroform-d) $\delta 8.36(\mathrm{~s}, 1 \mathrm{H}), 7.50-7.38(\mathrm{~m}, 3 \mathrm{H}), 6.92(\mathrm{~s}, 1 \mathrm{H}), 6.76$ $(\mathrm{d}, J=8.5 \mathrm{~Hz}, 1 \mathrm{H}), 3.89(\mathrm{~s}, 3 \mathrm{H}), 3.84(\mathrm{~s}, 3 \mathrm{H}), 3.72(\mathrm{~s}, 3 \mathrm{H}), 3.11(\mathrm{~d}, J=10.7 \mathrm{~Hz}, 1 \mathrm{H}), 3.07-2.98$ (m, 2H), $2.96-2.89(\mathrm{~m}, 1 \mathrm{H}), 2.80(\mathrm{t}, J=12.1 \mathrm{~Hz}, 1 \mathrm{H}), 2.64(\mathrm{~d}, J=12.2 \mathrm{~Hz}, 2 \mathrm{H}), 2.49(\mathrm{~d}, J=11.4$ 
$\mathrm{Hz}, 1 \mathrm{H}), 1.95(\mathrm{~d}, J=13.6 \mathrm{~Hz}, 1 \mathrm{H}), 1.76-1.61(\mathrm{~m}, 4 \mathrm{H}), 1.21(\mathrm{t}, J=6.7 \mathrm{~Hz}, 1 \mathrm{H}), 0.82(\mathrm{t}, J=7.2$

Hz, 3H). ${ }^{13} \mathrm{C}$ NMR (100 MHz, Chloroform-d) $\delta 183.61,169.56,160.82,154.70,151.65,142.60$, $141.92,128.39,127.51,122.41,118.88,111.85,109.50,109.29,81.28,61.69,61.64,58.19,55.79$, 51.49, 50.21, 40.62, 39.71, 36.54, 26.49, 19.17, 13.05. HRMS (ESI-TOF) $m / z:[\mathrm{M}+\mathrm{H}]^{+}$Calcd for $\mathrm{C}_{27} \mathrm{H}_{33} \mathrm{~N}_{2} \mathrm{O}_{6} 481.2333$; found 481.2328 .

methyl(E)-2-((2S,3S,7aS,12bS)-3-ethyl-7a-hydroxy-8-methoxy-9-methyl-1,2,3,4,6,7,7a,12boctahydroindolo[2,3-a]quinolizin-2-yl)-3-methoxyacrylate (SC33): A saturated aq. $\mathrm{NaHCO}_{3}$ (3 $\mathrm{mL})$ was added to a solution of $\mathbf{S C 2 3}(41.2 \mathrm{mg}, 0.10 \mathrm{mmol})$ in acetone $(4 \mathrm{~mL})$ at $0{ }^{\circ} \mathrm{C}$ resulting in suspension formation. A solution of oxone ${ }^{\circledR}(30.6 \mathrm{mg}, 0.20 \mathrm{mmol})$ in distilled water $(1 \mathrm{~mL})$ was added dropwise over 5 min period. The reaction mixture was stirred for additional $30 \mathrm{~min}$ at $0{ }^{\circ} \mathrm{C}$. Then, the content was diluted with water $(2-3 \mathrm{~mL})$ and the product was extracted in ethyl acetate $(3 \times 10 \mathrm{~mL})$. EtOAc layer was washed with brine $(15 \mathrm{~mL})$, dried over anhydrous $\mathrm{Na}_{2} \mathrm{SO}_{4}$, and filtered. Solvent was removed under reduced pressure and the content was purified by flash column chromatography (gradient: 25-65\% EtOAc in hexanes); to yield $18.8 \mathrm{mg}$ (44\%) of SC33 as a white solid. ${ }^{1} \mathrm{H}$ NMR (400 MHz, Chloroform- $d$ ) $\delta 7.44(\mathrm{~s}, 1 \mathrm{H}), 7.23(\mathrm{~d}, J=7.7 \mathrm{~Hz}, 1 \mathrm{H}), 7.14$ (d, $J=7.7$ Hz, 1H), 3.89 (s, 3H), $3.81(\mathrm{~s}, 3 \mathrm{H}), 3.68(\mathrm{~s}, 3 \mathrm{H}), 3.14-2.96(\mathrm{~m}, 3 \mathrm{H}), 2.86-2.74(\mathrm{~m}, 2 \mathrm{H}), 2.70-$ $2.59(\mathrm{~m}, 2 \mathrm{H}), 2.47(\mathrm{dd}, J=11.5,3.1 \mathrm{~Hz}, 1 \mathrm{H}), 2.29(\mathrm{~s}, 3 \mathrm{H}), 1.87(\mathrm{~d}, J=13.6 \mathrm{~Hz}, 1 \mathrm{H}), 1.77-1.64$ $(\mathrm{m}, 3 \mathrm{H}), 1.59(\mathrm{~d}, J=11.7 \mathrm{~Hz}, 1 \mathrm{H}), 1.24-1.18(\mathrm{~m}, 1 \mathrm{H}), 0.82(\mathrm{t}, J=7.3 \mathrm{~Hz}, 3 \mathrm{H}) .{ }^{13} \mathrm{C}$ NMR $(100$ MHz, Chloroform- $d) \delta 183.05,169.32,160.76,155.27,153.54,132.35,131.68,129.29,116.99$, $111.24,80.92,61.79,61.73,61.50,58.19,51.30,50.19,40.52,39.30,36.06,26.10,18.95,15.77$ 12.81. HRMS (ESI-TOF) $m / z:[\mathrm{M}+\mathrm{H}]^{+}$Calcd for $\mathrm{C}_{24} \mathrm{H}_{32} \mathrm{~N}_{2} \mathrm{O}_{5} 429.2384$; found 429.2380. 
methyl(E)-2-((2S,3S,12bS)-3-ethyl-11-(furan-3-yl)-8-methoxy-1,2,3,4,6,7,12,12b-

octahydroindolo[2,3-a]quinolizin-2-yl)-3-methoxyacrylate (SC71): 7 (71.6 mg, $0.15 \mathrm{mmol}$ ) was dissolved in dry toluene $(0.5 \mathrm{~mL})$ and the solvent was removed under reduced pressure to ensure azeotropic removal of water residues. Dry methanol $(1 \mathrm{~mL})$ and dry toluene $(1.5 \mathrm{~mL})$ were added. To the resulting solution were added 3 -furanylboronic acid (17.9 mg, $0.16 \mathrm{mmol}, 1.1$ equiv), $\mathrm{K}_{2} \mathrm{CO}_{3}$ (41.5 mg, 2 equiv) and $\mathrm{Pd}\left(\mathrm{PPh}_{3}\right)_{4}\left(8.7 \mathrm{mg}, 0.05\right.$ equiv). The mixture was stirred at $80{ }^{\circ} \mathrm{C}$ for 8 hrs. The solvent was evaporated under reduced pressure and the residue was extracted with DCM $(3 \times 20 \mathrm{~mL})$. The combined extracts were washed with brine $(3 \times 1 / 3$ vol. $)$, dried $\left(\mathrm{Na}_{2} \mathrm{SO}_{4}\right)$ and concentrated to provide the crude product. The crude product was purified by flash column chromatography (gradient: 25-70\% EtOAc in hexanes) to yield $48 \mathrm{mg}(69 \%)$ of SC71 as a yellow amorphous solid. ${ }^{1} \mathrm{H}$ NMR (500 MHz, Chloroform- $d$ ) $\delta 7.75(\mathrm{~s}, 1 \mathrm{H}), 7.68(\mathrm{dd}, J=1.5,0.9 \mathrm{~Hz}$, 1H), $7.54(\mathrm{t}, J=1.7 \mathrm{~Hz}, 1 \mathrm{H}), 7.43(\mathrm{~s}, 1 \mathrm{H}), 7.03(\mathrm{~d}, J=8.0 \mathrm{~Hz}, 1 \mathrm{H}), 6.70(\mathrm{dd}, J=1.8,0.9 \mathrm{~Hz}, 1 \mathrm{H})$, $6.50(\mathrm{~d}, J=8.0 \mathrm{~Hz}, 1 \mathrm{H}), 3.90(\mathrm{~s}, 3 \mathrm{H}), 3.73(\mathrm{~s}, 3 \mathrm{H}), 3.70(\mathrm{~s}, 3 \mathrm{H}), 3.21-3.09(\mathrm{~m}, 2 \mathrm{H}), 3.09-2.96$ (m, 3H), $2.93(\mathrm{dd}, J=11.3,5.6 \mathrm{~Hz}, 1 \mathrm{H}), 2.58-2.44(\mathrm{~m}, 3 \mathrm{H}), 1.84-1.74(\mathrm{~m}, 2 \mathrm{H}), 1.62(\mathrm{~s}, 1 \mathrm{H})$, 1.21 (dddd, $J=13.5,7.4,3.3,1.0 \mathrm{~Hz}, 1 \mathrm{H}), 0.87(\mathrm{t}, J=7.4 \mathrm{~Hz}, 3 \mathrm{H}) .{ }^{13} \mathrm{C} \mathrm{NMR}(100 \mathrm{MHz}$, Chloroform- $d$ ) $\delta 169.18,160.59,154.07,143.53,138.19,135.00,134.01,123.84,121.19,117.83$, $111.48,110.31,109.51,108.81,100.22,61.53,61.38,57.81,55.48,53.71,51.31,40.78,39.87$ 30.00, 23.90, 19.17, 12.89. HRMS (ESI-TOF) $m / z:[\mathrm{M}+\mathrm{H}]^{+}$Calcd for $\mathrm{C}_{27} \mathrm{H}_{33} \mathrm{~N}_{2} \mathrm{O}_{5} 465.2384$; found 465.2383.

methyl(E)-2-((2S,3S,12bS)-3-ethyl-8-methoxy-11-phenyl-1,2,3,4,6,7,12,12b-

octahydroindolo[2,3-a]quinolizin-2-yl)-3-methoxyacrylate (SC72): 7 (71.6 mg, $0.15 \mathrm{mmol}$ ) was dissolved in dry toluene $(0.5 \mathrm{~mL})$ and the solvent was removed under reduced pressure to ensure 
azeotropic removal of water residues. Dry methanol $(1 \mathrm{~mL})$ and dry toluene $(1.5 \mathrm{~mL})$ were added. To the resulting solution were added phenylboronic acid (19.5 mg, $0.16 \mathrm{mmol}, 1.1$ equiv), $\mathrm{K}_{2} \mathrm{CO}_{3}$ (41.5 mg, 2 equiv) and $\mathrm{Pd}\left(\mathrm{PPh}_{3}\right)_{4}\left(8.7 \mathrm{mg}, 0.05\right.$ equiv). The mixture was stirred at $80{ }^{\circ} \mathrm{C}$ for $8 \mathrm{hrs}$. The solvent was evaporated under reduced pressure and the residue was extracted with DCM $(3 \times 20 \mathrm{~mL})$. The combined extracts were washed with brine $(3 \times 1 / 3$ vol. $)$, dried $\left(\mathrm{Na}_{2} \mathrm{SO}_{4}\right)$ and concentrated to provide the crude product. The crude product was purified by flash column chromatography (gradient: $25-70 \%$ EtOAc in hexanes) to yield $47.7 \mathrm{mg}(67 \%)$ of SC72 as a light yellow solid. ${ }^{1} \mathrm{H}$ NMR (400 MHz, Chloroform- $d$ ) $\delta 7.87$ (s, 1H), 7.59 (dd, $\left.J=8.0,1.4 \mathrm{~Hz}, 2 \mathrm{H}\right)$, $7.47(\mathrm{t}, J=7.6 \mathrm{~Hz}, 2 \mathrm{H}), 7.40(\mathrm{~d}, J=0.8 \mathrm{~Hz}, 1 \mathrm{H}), 7.37-7.32(\mathrm{~m}, 1 \mathrm{H}), 7.02(\mathrm{~d}, J=7.9 \mathrm{~Hz}, 1 \mathrm{H})$, $6.55(\mathrm{~d}, J=8.0 \mathrm{~Hz}, 1 \mathrm{H}), 3.91(\mathrm{~s}, 3 \mathrm{H}), 3.70(\mathrm{~s}, 3 \mathrm{H}), 3.68(\mathrm{~s}, 3 \mathrm{H}), 3.20-3.11(\mathrm{~m}, 2 \mathrm{H}), 3.06-2.98$ (m, 3H), $2.93(\mathrm{dd}, J=11.3,5.5 \mathrm{~Hz}, 1 \mathrm{H}), 2.59-2.51(\mathrm{~m}, 1 \mathrm{H}), 2.46(\mathrm{dd}, J=11.3,2.7 \mathrm{~Hz}, 2 \mathrm{H}), 1.82$ $-1.69(\mathrm{~m}, 2 \mathrm{H}), 1.61(\mathrm{~s}, 1 \mathrm{H}), 1.28-1.16(\mathrm{~m}, 1 \mathrm{H}), 0.86(\mathrm{t}, J=7.4 \mathrm{~Hz}, 3 \mathrm{H}) .{ }^{13} \mathrm{C} \mathrm{NMR}(100 \mathrm{MHz}$, Chloroform- $d$ ) $\delta 169.15,160.47,154.16,139.68,134.72,133.93,127.99,127.99,126.63,122.03$, $118.82,117.75,111.42,108.55,100.35,61.47,61.39,57.80,55.35,53.70,51.25,40.75,39.81$, 29.93, 23.90, 19.13, 12.85. HRMS (ESI-TOF) $m / z:[\mathrm{M}+\mathrm{H}]^{+}$Calcd for $\mathrm{C}_{29} \mathrm{H}_{34} \mathrm{~N}_{2} \mathrm{O}_{4} 475.2591$; found 475.2590 .

methyl(E)-2-((2S,3S,12bS)-3-ethyl-8-methoxy-11-methyl-1,2,3,4,6,7,12,12b-

octahydroindolo[2,3-a]quinolizin-2-yl)-3-methoxyacrylate (SC73): Starting material 7 (71.6 mg, $0.15 \mathrm{mmol}), \mathrm{Pd}_{2}(\mathrm{dba})_{3}(13.7 \mathrm{mg}, 0.1$ equiv), Xphos (10.7 mg, 0.15 equiv) and DABAL- Me3 (153.8 mg, 4 equiv) were balanced into an oven dried vial. Vial was purged with argon and dry THF (3 mL) was added under argon. Vial was sealed with a Teflon lined screw cap and heated to $60{ }^{\circ} \mathrm{C}$. After stirring for $8 \mathrm{~h}$ complete conversion was observed by LC-MS. The reaction mixture 
was cooled to RT and concentrated in vacuo. The product was purified by flash column chromatography (gradient: $25-75 \%$ EtOAc in hexanes); to yield $35.9 \mathrm{mg}$ (87\%) of SC73 as a yellow solid. ${ }^{1} \mathrm{H}$ NMR (500 MHz, Chloroform- $\left.d\right) \delta 7.52(\mathrm{~s}, 1 \mathrm{H}), 7.44(\mathrm{~s}, 1 \mathrm{H}), 6.78(\mathrm{dd}, J=7.8$, $1.0 \mathrm{~Hz}, 1 \mathrm{H}), 6.38(\mathrm{~d}, J=7.8 \mathrm{~Hz}, 1 \mathrm{H}), 3.85(\mathrm{~s}, 3 \mathrm{H}), 3.74(\mathrm{~s}, 3 \mathrm{H}), 3.71(\mathrm{~s}, 3 \mathrm{H}), 3.18(\mathrm{dd}, J=11.4$, $2.3 \mathrm{~Hz}, 1 \mathrm{H}), 3.15-3.00(\mathrm{~m}, 3 \mathrm{H}), 2.99-2.88(\mathrm{~m}, 2 \mathrm{H}), 2.57-2.43(\mathrm{~m}, 3 \mathrm{H}), 2.37(\mathrm{~s}, 3 \mathrm{H}), 1.87-$ $1.75(\mathrm{~m}, 2 \mathrm{H}), 1.62(\mathrm{~d}, J=10.6 \mathrm{~Hz}, 1 \mathrm{H}), 1.21(\mathrm{dddd}, J=12.3,11.2,5.0,2.8 \mathrm{~Hz}, 1 \mathrm{H}), 0.88(\mathrm{~d}, J=$ $7.3 \mathrm{~Hz}, 3 \mathrm{H}) .{ }^{13} \mathrm{C}$ NMR (100 MHz, Chloroform- $\left.d\right) \delta 169.20,160.48,152.93,136.41,133.48$, $121.86,117.11,112.85,111.57,108.50,99.90,61.54,61.38,57.79,55.49,53.75,51.35,40.74$ 39.87, 30.00, 23.87, 19.11, 16.07, 12.86. HRMS (ESI-TOF) $m / z:[\mathrm{M}+\mathrm{H}]^{+}$Calcd for $\mathrm{C}_{24} \mathrm{H}_{33} \mathrm{~N}_{2} \mathrm{O}_{4}$ 413.2435; found 413.2435.

methyl(E)-2-((2S,3S,7aS,12bS)-3-ethyl-11-(furan-3-yl)-7a-hydroxy-8-methoxy1,2,3,4,6,7,7a,12b-octahydroindolo[2,3-a]quinolizin-2-yl)-3-methoxyacrylate $\quad$ (SC81): A saturated aq. $\mathrm{NaHCO}_{3}(3 \mathrm{~mL})$ was added to a solution of $\mathbf{S C 7 1}(46.4 \mathrm{mg}, 0.10 \mathrm{mmol})$ in acetone $(4 \mathrm{~mL})$ at $0{ }^{\circ} \mathrm{C}$ resulting in suspension formation. A solution of oxone ${ }^{\circledR}(30.6 \mathrm{mg}, 0.20 \mathrm{mmol})$ in distilled water $(1 \mathrm{~mL})$ was added dropwise over 5 min period. The reaction mixture was stirred for additional $30 \mathrm{~min}$ at $0{ }^{\circ} \mathrm{C}$. Then, the content was diluted with water $(2-3 \mathrm{~mL})$ and the product was extracted in ethyl acetate $(3 \times 10 \mathrm{~mL})$. EtOAc layer was washed with brine $(15 \mathrm{~mL})$, dried over anhydrous $\mathrm{Na}_{2} \mathrm{SO}_{4}$, and filtered. Solvent was removed under reduced pressure and the content was purified by flash column chromatography (gradient: 25-65\% EtOAc in hexanes); to yield $21.6 \mathrm{mg}$ (45\%) of SC81 as a white solid. ${ }^{1} \mathrm{H}$ NMR (500 MHz, Chloroform- $d$ ) $\delta 8.35(\mathrm{dd}, J=1.6,0.8 \mathrm{~Hz}$, 1H), $7.46(\mathrm{~s}, 1 \mathrm{H}), 7.45-7.42(\mathrm{~m}, 2 \mathrm{H}), 6.92(\mathrm{dd}, J=1.9,0.8 \mathrm{~Hz}, 1 \mathrm{H}), 6.75(\mathrm{~d}, J=8.6 \mathrm{~Hz}, 1 \mathrm{H})$, $3.88(\mathrm{~s}, 3 \mathrm{H}), 3.83(\mathrm{~s}, 3 \mathrm{H}), 3.72(\mathrm{~s}, 3 \mathrm{H}), 3.11(\mathrm{dd}, J=11.0,2.6 \mathrm{~Hz}, 1 \mathrm{H}), 3.05-2.98(\mathrm{~m}, 2 \mathrm{H}), 2.96$ 
$-2.87(\mathrm{~m}, 1 \mathrm{H}), 2.84-2.77(\mathrm{~m}, 1 \mathrm{H}), 2.63(\mathrm{ddt}, J=13.8,6.5,2.3 \mathrm{~Hz}, 2 \mathrm{H}), 2.49$ (ddd, $J=11.4,3.1$, $1.0 \mathrm{~Hz}, 1 \mathrm{H}), 2.18(\mathrm{~s}, 1 \mathrm{H}), 1.95(\mathrm{dtd}, J=13.5,3.0,1.2 \mathrm{~Hz}, 1 \mathrm{H}), 1.74-1.63(\mathrm{~m}, 3 \mathrm{H}), 1.25-1.20$ $(\mathrm{m}, 1 \mathrm{H}), 0.82(\mathrm{t}, J=7.3 \mathrm{~Hz}, 3 \mathrm{H}) .{ }^{13} \mathrm{C}$ NMR $(100 \mathrm{MHz}$, Chloroform- $d) \delta 183.61,169.56,160.82$, $154.70,151.65,142.60,141.92,128.39,127.51,122.41,118.88,111.85,109.50,109.29,81.28$, $61.69,61.64,58.19,55.79,51.49,50.21,40.62,39.71,36.54,26.49,19.17,13.05$. HRMS (ESITOF) $m / z:[\mathrm{M}+\mathrm{H}]^{+}$Calcd for $\mathrm{C}_{27} \mathrm{H}_{33} \mathrm{~N}_{2} \mathrm{O}_{6}$ 481.2333; found 481.2329.

methyl(E)-2-((2S,3S,7aS,12bS)-3-ethyl-7a-hydroxy-8-methoxy-11-phenyl-1,2,3,4,6,7,7a,12boctahydroindolo[2,3-a]quinolizin-2-yl)-3-methoxyacrylate (SC82): A saturated aq. $\mathrm{NaHCO}_{3}(3$ $\mathrm{mL})$ was added to a solution of $\mathbf{S C 7 2}(47.4 \mathrm{mg}, 0.10 \mathrm{mmol})$ in acetone $(4 \mathrm{~mL})$ at $0{ }^{\circ} \mathrm{C}$ resulting in suspension formation. A solution of oxone ${ }^{\circledR}(30.6 \mathrm{mg}, 0.20 \mathrm{mmol})$ in distilled water $(1 \mathrm{~mL})$ was added dropwise over 5 min period. The reaction mixture was stirred for additional $30 \mathrm{~min}$ at $0{ }^{\circ} \mathrm{C}$. Then, the content was diluted with water $(2-3 \mathrm{~mL})$ and the product was extracted in ethyl acetate (3x10 mL). EtOAc layer was washed with brine $(15 \mathrm{~mL})$, dried over anhydrous $\mathrm{Na}_{2} \mathrm{SO}_{4}$, and filtered. Solvent was removed under reduced pressure and the content was purified by flash column chromatography (gradient: 25-65\% EtOAc in hexanes); to yield $20.1 \mathrm{mg}$ (41\%) of SC82 as a white solid. ${ }^{1} \mathrm{H}$ NMR (400 MHz, Chloroform- $d$ ) $\delta 7.87(\mathrm{~d}, J=7.1 \mathrm{~Hz}, 2 \mathrm{H}), 7.48(\mathrm{~d}, J=8.6 \mathrm{~Hz}, 1 \mathrm{H}), 7.40$ $(\mathrm{dd}, J=14.8,7.2 \mathrm{~Hz}, 3 \mathrm{H}), 7.30(\mathrm{~d}, J=7.4 \mathrm{~Hz}, 1 \mathrm{H}), 6.82(\mathrm{~d}, J=8.6 \mathrm{~Hz}, 1 \mathrm{H}), 3.91(\mathrm{~s}, 3 \mathrm{H}), 3.78(\mathrm{~s}$, 3H), $3.70(\mathrm{~s}, 3 \mathrm{H}), 3.13-3.07(\mathrm{~m}, 1 \mathrm{H}), 3.06-2.94(\mathrm{~m}, 2 \mathrm{H}), 2.83(\mathrm{dt}, J=21.6,12.1 \mathrm{~Hz}, 2 \mathrm{H}), 2.70$ $-2.61(\mathrm{~m}, 2 \mathrm{H}), 2.48(\mathrm{~d}, J=11.4 \mathrm{~Hz}, 1 \mathrm{H}), 1.90(\mathrm{~d}, J=13.8 \mathrm{~Hz}, 1 \mathrm{H}), 1.79-1.61(\mathrm{~m}, 4 \mathrm{H}), 1.21(\mathrm{~d}$, $J=7.2 \mathrm{~Hz}, 1 \mathrm{H}), 0.82(\mathrm{t}, J=7.2 \mathrm{~Hz}, 3 \mathrm{H}) .{ }^{13} \mathrm{C}$ NMR (100 MHz, Chloroform- $\left.d\right) \delta 183.40,169.36$, $160.56,155.07,151.97,137.82,130.84,129.44,127.86,127.26,127.12,126.64,111.54,109.30$, $80.99,61.47,61.33,57.99,55.51,51.20,50.02,40.34,39.47,36.19,26.06,18.93,12.82$. HRMS (ESI-TOF) $m / z:[\mathrm{M}+\mathrm{H}]^{+}$Calcd for $\mathrm{C}_{29} \mathrm{H}_{35} \mathrm{~N}_{2} \mathrm{O}_{5}$ 491.2540; found 491.2542. 
methyl(E)-2-((2S,3S,7aS,12bS)-3-ethyl-7a-hydroxy-8-methoxy-11-methyl-1,2,3,4,6,7,7a,12boctahydroindolo[2,3-a]quinolizin-2-yl)-3-methoxyacrylate (SC83): A saturated aq. $\mathrm{NaHCO}_{3}$ (3 $\mathrm{mL})$ was added to a solution of $\mathbf{S C 7 3}(41.2 \mathrm{mg}, 0.10 \mathrm{mmol})$ in acetone $(4 \mathrm{~mL})$ at $0{ }^{\circ} \mathrm{C}$ resulting in suspension formation. A solution of oxone ${ }^{\circledR}(30.6 \mathrm{mg}, 0.20 \mathrm{mmol})$ in distilled water $(1 \mathrm{~mL})$ was added dropwise over 5 min period. The reaction mixture was stirred for additional $30 \mathrm{~min}$ at $0{ }^{\circ} \mathrm{C}$. Then, the content was diluted with water $(2-3 \mathrm{~mL})$ and the product was extracted in ethyl acetate (3x10 mL). EtOAc layer was washed with brine $(15 \mathrm{~mL})$, dried over anhydrous $\mathrm{Na}_{2} \mathrm{SO}_{4}$, and filtered. Solvent was removed under reduced pressure and the content was purified by flash column chromatography (gradient: $25-65 \%$ EtOAc in hexanes); to yield $23.6 \mathrm{mg}(55 \%)$ of SC83 as a white solid. ${ }^{1} \mathrm{H}$ NMR (400 MHz, Chloroform- $d$ ) $\delta 7.44(\mathrm{~s}, 1 \mathrm{H}), 7.04$ (d, $\left.J=7.6 \mathrm{~Hz}, 1 \mathrm{H}\right), 6.61$ (d, $J=8.6$ $\mathrm{Hz}, 1 \mathrm{H}), 3.82(\mathrm{~s}, 3 \mathrm{H}), 3.81(\mathrm{~s}, 3 \mathrm{H}), 3.71(\mathrm{~s}, 3 \mathrm{H}), 3.04(\mathrm{ddd}, J=13.6,10.9,7.5 \mathrm{~Hz}, 3 \mathrm{H}), 2.87-2.73$ $(\mathrm{m}, 2 \mathrm{H}), 2.66-2.56(\mathrm{~m}, 2 \mathrm{H}), 2.50-2.45(\mathrm{~m}, 1 \mathrm{H}), 2.44(\mathrm{~s}, 3 \mathrm{H}), 1.94-1.87(\mathrm{~m}, 1 \mathrm{H}), 1.77-1.66$ $(\mathrm{m}, 2 \mathrm{H}), 1.66-1.56(\mathrm{~m}, 2 \mathrm{H}), 1.27-1.21(\mathrm{~m}, 1 \mathrm{H}), 0.82(\mathrm{t}, J=7.3 \mathrm{~Hz}, 3 \mathrm{H}) .{ }^{13} \mathrm{C} \mathrm{NMR}(100 \mathrm{MHz}$ Chloroform- $d$ ) $\delta 182.80,169.29,160.52,153.91,153.03,131.77,126.22,123.41,111.56,108.67$, $81.22,61.66,61.55,58.18,55.42,51.27,50.10,40.52,39.28,35.85,25.98,18.98,15.73,12.81$. HRMS (ESI-TOF) $m / z:[\mathrm{M}+\mathrm{H}]^{+}$Calcd for $\mathrm{C}_{24} \mathrm{H}_{33} \mathrm{~N}_{2} \mathrm{O}_{5} 429.2384$; found 429.2380 .

\section{REFERENCES}

(1) Pasternak, G. W.; Pan, Y.-X. Mu Opioids and Their Receptors: Evolution of a Concept. Pharmacol Rev. 2013, 65 (4), 1257-317.

(2) Corbett, A. D.; Henderson, G.; Mcknight, A. T.; Paterson, S. J. 75 Years of Opioid Research: The Exciting but Vain Quest for the Holy Grail. Br J Pharmacol 2006, 147 (Suppl 1), S153-162.

(3) Compton, W. M.; Jones, C. M.; Baldwin, G. T. The Authors Reply. New England Journal of Medicine. Massachussetts Medical Society March 31, 2016, p 1296. 
(4) Overdose Death Rates | National Institute on Drug Abuse (NIDA)

https://www.drugabuse.gov/related-topics/trends-statistics/overdose-death-rates (accessed Sep 23, 2019).

(5) Gillis, A.; Gondin, A. B.; Kliewer, A.; Sanchez, J.; Lim, H. D.; Alamein, C.; Manandhar, P.; Santiago, M.; Fritzwanker, S.; Schmiedel, F.; Katte, T. A.; Reekie, T.; Grimsey, N. L.; Kassiou, M.; Kellam, B.; Krasel, C.; Halls, M. L.; ... Canals, M. Low Intrinsic Efficacy for G Protein Activation Can Explain the Improved Side Effect Profiles of New Opioid Agonists. Sci. Signal. 2020, 13 (625), 31.

(6) Che, T.; Roth, B. L. Structural Insights Accelerate the Discovery of Opioid Alternatives. Annu Rev Biochem 2021, in press.

(7) Uprety, R.; Che, T.; Zaidi, S. A.; Grinnell, S. G.; Varga, B. R.; Faouzi, A.; Slocum, S. T.; Allaoa, A.; Varadi, A.; Nelson, M.; Bernhard, S. M.; Kulko, E.; LeRouzic, V.; Eans, S. O.; Simons, C. A.; Hunkele, A.; Subrath, J.; ... Majumdar, S. Controlling Opioid Receptor Functional Selectivity by Targeting Distinct Subpockets of the Orthosteric Site. Elife 2021, 10 .

(8) Kelly, E. Efficacy and Ligand Bias at the $\mu$-Opioid Receptor. British Journal of Pharmacology. Wiley-Blackwell August 2013, pp 1430-1446.

(9) McPherson, J.; Rivero, G.; Baptist, M.; Llorente, J.; Al-Sabah, S.; Krasel, C.; Dewey, W. L.; Bailey, C. P.; Rosethorne, E. M.; Charlton, S. J.; Henderson, G.; Kelly, E. $\mu$-Opioid Receptors: Correlation of Agonist Efficacy for Signalling with Ability to Activate Internalization. Mol. Pharmacol. 2010, 78 (4), 756-766.

(10) Ramanathan, S.; McCurdy, C. R. Kratom (Mitragyna Speciosa): Worldwide Issues. Curr. Opin. Psychiatry 2020, 33 (4), 312-318.

(11) Chakraborty, S.; Majumdar, S. Natural Products for the Treatment of Pain: Chemistry and Pharmacology of Salvinorin A, Mitragynine, and Collybolide. Biochemistry 2020, in press.

(12) Todd, D. A.; Kellogg, J. J.; Wallace, E. D.; Khin, M.; Flores-Bocanegra, L.; Tanna, R. S.; McIntosh, S.; Raja, H. A.; Graf, T. N.; Hemby, S. E.; Paine, M. F.; Oberlies, N. H.; Cech, N. B. Chemical Composition and Biological Effects of Kratom (Mitragyna Speciosa): In Vitro Studies with Implications for Efficacy and Drug Interactions. Sci. Rep. 2020, 10 (1), $1-13$.

(13) Brown, P. N.; Lund, J. A.; Murch, S. J. A Botanical, Phytochemical and Ethnomedicinal Review of the Genus Mitragyna Korth: Implications for Products Sold as Kratom. Journal of Ethnopharmacology. Elsevier Ireland Ltd April 18, 2017, pp 302-325.

(14) Ellis, C. R.; Racz, R.; Kruhlak, N. L.; Kim, M. T.; Zakharov, A. V.; Southall, N.; Hawkins, E. G.; Burkhart, K.; Strauss, D. G.; Stavitskaya, L. Evaluating Kratom Alkaloids Using PHASE. PLoS One 2020, 15 (3).

(15) Takayama, H. Chemistry and Pharmacology of Analgesic Indole Alkaloids from the 
Rubiaceous Plant, Mitragyna Speciosa. Chem Pharm Bull 2004, 52 (8), 916-28.

(16) Takayama, H.; Ishikawa, H.; Kurihara, M.; Kitajima, M.; Aimi, N.; Ponglux, D.; Koyama, F.; Matsumoto, K.; Moriyama, T.; Yamamoto, L. T.; Watanabe, K.; Murayama, T.; Horie, S. Studies on the Synthesis and Opioid Agonistic Activities of Mitragynine-Related Indole Alkaloids: Discovery of Opioid Agonists Structurally Different from Other Opioid Ligands. J. Med. Chem. 2002, 45 (9), 1949-1956.

(17) Kruegel, A. C.; Gassaway, M. M.; Kapoor, A.; Váradi, A.; Majumdar, S.; Filizola, M.; Javitch, J. A.; Sames, D. Synthetic and Receptor Signaling Explorations of the Mitragyna Alkaloids: Mitragynine as an Atypical Molecular Framework for Opioid Receptor Modulators. J. Am. Chem. Soc. 2016, 138 (21), 6754-6764.

(18) Váradi, A.; Marrone, G. F.; Palmer, T. C.; Narayan, A.; Szabó, M. R.; Le Rouzic, V.; Grinnell, S. G.; Subrath, J. J.; Warner, E.; Kalra, S.; Hunkele, A.; Pagirsky, J.; Eans, S. O.; Medina, J. M.; Xu, J.; Pan, Y. X.; Borics, A.; ... Majumdar, S.

Mitragynine/Corynantheidine Pseudoindoxyls As Opioid Analgesics with Mu Agonism and Delta Antagonism, Which Do Not Recruit $\beta$-Arrestin-2. J. Med. Chem. 2016, 59 (18), 8381-8397.

(19) Kruegel, A. C.; Uprety, R.; Grinnell, S. G.; Langreck, C.; Pekarskaya, E. A.; Le Rouzic, V.; Ansonoff, M.; Gassaway, M. M.; Pintar, J. E.; Pasternak, G. W.; Javitch, J. A.; Majumdar, S.; Sames, D. 7-Hydroxymitragynine Is an Active Metabolite of Mitragynine and a Key Mediator of Its Analgesic Effects. ACS Cent. Sci. 2019, 5 (6), 992-1001.

(20) Stoeber, M.; Jullié, D.; Li, J.; Chakraborty, S.; Majumdar, S.; Lambert, N. A.; Manglik, A.; von Zastrow, M. Agonist-Selective Recruitment of Engineered Protein Probes and of GRK2 by Opioid Receptors in Living Cells. Elife 2020, 9, e54208.

(21) Zhou, Y.; Ramsey, S.; Provasi, D.; El Daibani, A.; Appourchaux, K.; Chakraborty, S.; Kapoor, A.; Che, T.; Majumdar, S.; Filizola, M. Predicted Mode of Binding to and Allosteric Modulation of the $\mu$-Opioid Receptor by Kratom's Alkaloids with Reported Antinociception In Vivo. Biochemistry 2020, acs.biochem.0c00658.

(22) Gutridge, A. M.; Robins, M. T.; Cassell, R. J.; Uprety, R.; Mores, K. L.; Ko, M. J.; Pasternak, G. W.; Majumdar, S.; van Rijn, R. M. G Protein-Biased Kratom-Alkaloids and Synthetic Carfentanil-Amide Opioids as Potential Treatments for Alcohol Use Disorder. Br. J. Pharmacol. 2019, bph.14913.

(23) Wilson, L. L.; Chakraborty, S.; Eans, S. O.; Cirino, T. J.; Stacy, H. M.; Simons, C. A.; Uprety, R.; Majumdar, S.; McLaughlin, J. P. Kratom Alkaloids, Natural and SemiSynthetic, Show Less Physical Dependence and Ameliorate Opioid Withdrawal. Cell. Mol. Neurobiol. 2021, in press.

(24) Kamble, S. H.; Sharma, A.; King, T. I.; León, F.; McCurdy, C. R.; Avery, B. A. Metabolite Profiling and Identification of Enzymes Responsible for the Metabolism of Mitragynine, the Major Alkaloid of Mitragyna Speciosa (Kratom). Xenobiotica 2019, 49 (11), 1279-1288. 
(25) Maxwell, E. A.; King, T. I.; Kamble, S. H.; Raju, K. S. R.; Berthold, E. C.; León, F.; Avery, B. A.; McMahon, L. R.; McCurdy, C. R.; Sharma, A. Pharmacokinetics and Safety of Mitragynine in Beagle Dogs. Planta Med. 2020.

(26) Wilson, L. L.; Harris, H. M.; Eans, S. O.; Brice-Tutt, A. C.; Cirino, T. J.; Stacy, H. M.; Simons, C. A.; León, F.; Sharma, A.; Boyer, E. W.; Avery, B. A.; McLaughlin, J. P.; McCurdy, C. R. Lyophilized Kratom Tea as a Therapeutic Option for Opioid Dependence. Drug Alcohol Depend. 2020, 216, 108310.

(27) Hiranita, T.; Leon, F.; Felix, J. S.; Restrepo, L. F.; Reeves, M. E.; Pennington, A. E.; Obeng, S.; Avery, B. A.; McCurdy, C. R.; McMahon, L. R.; Wilkerson, J. L. The Effects of Mitragynine and Morphine on Schedule-Controlled Responding and Antinociception in Rats. Psychopharmacology (Berl). 2019, 236 (9), 2725-2734.

(28) Obeng, S.; Kamble, S. H.; Reeves, M. E.; Restrepo, L. F.; Patel, A.; Behnke, M.; Chear, N. J. Y.; Ramanathan, S.; Sharma, A.; León, F.; Hiranita, T.; Avery, B. A.; McMahon, L. R.; McCurdy, C. R. Investigation of the Adrenergic and Opioid Binding Affinities, Metabolic Stability, Plasma Protein Binding Properties, and Functional Effects of Selected Indole-Based Kratom Alkaloids. J. Med. Chem. 2020, 63 (1), 433-439.

(29) Yue, K.; Kopajtic, T. A.; Katz, J. L. Abuse Liability of Mitragynine Assessed with a SelfAdministration Procedure in Rats. Psychopharmacology (Berl). 2018, 235 (10), 2823 2829.

(30) Hemby, S. E.; McIntosh, S.; Leon, F.; Cutler, S. J.; McCurdy, C. R. Abuse Liability and Therapeutic Potential of the Mitragyna Speciosa (Kratom) Alkaloids Mitragynine and 7Hydroxymitragynine. Addict. Biol. 2019, 24 (5), 874-885.

(31) Takayama, H.; Misawa, K.; Okada, N.; Ishikawa, H.; Kitajima, M.; Hatori, Y.; Murayama, T.; Wongseripipatana, S.; Tashima, K.; Matsumoto, K.; Horie, S. New Procedure to Mask the 2,3- $\pi$ Bond of the Indole Nucleus and Its Application to the Preparation of Potent Opioid Receptor Agonists with a Corynanthe Skeleton. Org. Lett. 2006, 8 (25), 5705-5708.

Olsen, R. H. J.; DiBerto, J. F.; English, J. G.; Glaudin, A. M.; Krumm, B. E.; Slocum, S. T.; Che, T.; Gavin, A. C.; McCorvy, J. D.; Roth, B. L.; Strachan, R. T. TRUPATH, an Open-Source Biosensor Platform for Interrogating the GPCR Transducerome. Nat. Chem. Biol. 2020, 16 (8), 841-849.

(33) Barnett, M. E.; Knapp, B. I.; Bidlack, J. M. Unique Pharmacological Properties of the Kappa Opioid Receptor Signaling through Gaz as Shown with Bioluminescence Resonance Energy Tranfer. Mol. Pharmacol. 2020, 98 (4), 462-474.

(34) Che, T.; Majumdar, S.; Zaidi, S. A.; Ondachi, P.; McCorvy, J. D.; Wang, S.; Mosier, P. D.; Uprety, R.; Vardy, E.; Krumm, B. E.; Han, G. W.; Lee, M.-Y.; Pardon, E.; Steyaert, J.; Huang, X.-P.; Strachan, R. T.; Tribo, A. R.; ... Roth, B. L. Structure of the NanobodyStabilized Active State of the Kappa Opioid Receptor. Cell 2018, 172 (1-2), 55-67.e15.

Che, T.; English, J.; Krumm, B. E.; Kim, K.; Pardon, E.; Olsen, R. H. J.; Wang, S.; Zhang, 
S.; Diberto, J. F.; Sciaky, N.; Carroll, F. I.; Steyaert, J.; Wacker, D.; Roth, B. L. Nanobody-Enabled Monitoring of Kappa Opioid Receptor States. Nat. Commun. 2020, 11 (1).

(36) Margolis, E. B.; Fields, H. L.; Hjelmstad, G. O.; Mitchell, J. M. $\delta$-Opioid Receptor Expression in the Ventral Tegmental Area Protects against Elevated Alcohol Consumption. J. Neurosci. 2008, 28 (48), 12672-12681.

(37) Bhowmik, S.; Galeta, J.; Havel, V. V.; Nelson, M.; Faouzi, A.; Bechand, B.; Fiala, T.; Hunkele, A.; Kruegel, A. C.; Javitch, J. A.; Sames, D.; Majumdar, S.; Javitch, J. A.; Sames, D. Site Selective C-H Functionalization of Mitragyna Alkaloids Reveals a Molecular Switch for Tuning Opioid Receptor Signaling Efficacy. ChemRxiv 2020, 1-42.

(38) Bhowmik, S.; Galeta, J.; Havel, V. V.; Nelson, M.; Faouzi, A.; Bechand, B.; Fiala, T.; Hunkele, A.; Kruegel, A. C.; Javitch, J. A.; Sames, D.; Majumdar, S.; Javitch, J. A.; Sames, D. Site Selective C-H Functionalization of Mitragyna Alkaloids Reveals a Molecular Switch for Tuning Opioid Receptor Signaling Efficacy. Nat. Commun. 2021.

(39) Schrödinger, L., New York, NY. (2019) Small-Molecule Drug Discovery Suite 2019-2, 2018-3 Ed., Schrödinger, LLC.

(40) Ballesteros, J. A.; Weinstein, H. Integrated Methods for the Construction of ThreeDimensional Models and Computational Probing of Structure-Function Relations in G Protein-Coupled Receptors. Methods Neurosci. 1995, 25 (C), 366-428.

(41) Isberg, V.; De Graaf, C.; Bortolato, A.; Cherezov, V.; Katritch, V.; Marshall, F. H.; Mordalski, S.; Pin, J. P.; Stevens, R. C.; Vriend, G.; Gloriam, D. E. Generic GPCR Residue Numbers - Aligning Topology Maps While Minding the Gaps. Trends in Pharmacological Sciences. Elsevier Ltd January 1, 2015, pp 22-31.

(42) Matsumoto, K.; Horie, S.; Ishikawa, H.; Takayama, H.; Aimi, N.; Ponglux, D.; Watanabe, K. Antinociceptive Effect of 7-Hydroxymitragynine in Mice: Discovery of an Orally Active Opioid Analgesic from the Thai Medicinal Herb Mitragyna Speciosa. Life Sci. 2004, 74 (17), 2143-2155.

(43) Manglik, A.; Lin, H.; Aryal, D. K.; McCorvy, J. D.; Dengler, D.; Corder, G.; Levit, A.; Kling, R. C.; Bernat, V.; Hübner, H.; Huang, X. P.; Sassano, M. F.; Giguère, P. M.; Löber, S.; Duan, D.; Scherrer, G.; Kobilka, B. K.; ... Shoichet, B. K. Structure-Based Discovery of Opioid Analgesics with Reduced Side Effects. Nature 2016, 537 (7619), 185-190.

(44) Faouzi, A.; Varga, B. R.; Majumdar, S. Biased Opioid Ligands. Molecules. MDPI AG September 1, 2020, p 4257.

(45) Schmid, C. L.; Kennedy, N. M.; Ross, N. C.; Lovell, K. M.; Yue, Z.; Morgenweck, J.; Cameron, M. D.; Bannister, T. D.; Bohn, L. M. Bias Factor and Therapeutic Window Correlate to Predict Safer Opioid Analgesics. Cell 2017, 171 (5), 1165-1175.e13.

(46) Cuitavi, J.; Hipólito, L.; Canals, M. The Life Cycle of the Mu-Opioid Receptor. Trends in Biochemical Sciences. Elsevier Ltd October 27, 2020. 
(47) Faouzi, A.; Uprety, R.; Gomes, I.; Massaly, N.; Keresztes, A. I.; Le Rouzic, V.; Gupta, A.; Zhang, T.; Yoon, H. J.; Ansonoff, M.; Allaoa, A.; Pan, Y. X.; Pintar, J.; Morón, J. A.; Streicher, J. M.; Devi, L. A.; Majumdar, S. Synthesis and Pharmacology of a Novel $\mu-$ $\Delta$ Opioid Receptor Heteromer-Selective Agonist Based on the Carfentanyl Template. $J$. Med. Chem. 2020, 63 (22), 13618-13637.

(48) Kliewer, A.; Gillis, A.; Hill, R.; Schmiedel, F.; Bailey, C.; Kelly, E.; Henderson, G.; Christie, M. J.; Schulz, S. Morphine-Induced Respiratory Depression Is Independent of $\beta$ Arrestin2 Signalling. Br. J. Pharmacol. 2020, 177 (13), 2923-2931.

(49) Kliewer, A.; Schmiedel, F.; Sianati, S.; Bailey, A.; Bateman, J. T.; Levitt, E. S.; Williams, J. T.; Christie, M. J.; Schulz, S. Phosphorylation-Deficient G-Protein-Biased $\mu$-Opioid Receptors Improve Analgesia and Diminish Tolerance but Worsen Opioid Side Effects. Nat. Commun. 2019, 10 (1).

(50) Raehal, K. M.; Walker, J. K. L.; Bohn, L. M. Morphine Side Effects in $\beta$-Arrestin 2 Knockout Mice. J. Pharmacol. Exp. Ther. 2005, 314 (3), 1195-1201.

(51) Liapakis, G.; Chan, W. C.; Papadokostaki, M.; Javitch, J. A. Synergistic Contributions of the Functional Groups of Epinephrine to Its Affinity and Efficacy at the B2 Adrenergic Receptor. Mol. Pharmacol. 2004, 65 (5), 1181-1190.

(52) Kenakin, T. A Scale of Agonism and Allosteric Modulation for Assessment of Selectivity, Bias, and Receptor Mutation. Molecular Pharmacology. American Society for Pharmacology and Experimental Therapy October 1, 2017, pp 414-424.

(53) Selley, D. E.; Liu, Q.; Childers, S. R. Signal Transduction Correlates of Mu Opioid Agonist Intrinsic Efficacy: Receptor-Stimulated [35S]GTP $\gamma \mathrm{S}$ Binding in MMOR-CHO Cells and Rat Thalamus. J. Pharmacol. Exp. Ther. 1998, 285 (2), 496-505.

(54) Strange, P. G. Use of the GTP $\gamma \mathrm{S}$ ([ 35S]GTP $\gamma \mathrm{S}$ and Eu-GTP $\gamma \mathrm{S})$ Binding Assay for Analysis of Ligand Potency and Efficacy at G Protein-Coupled Receptors. British Journal of Pharmacology. John Wiley \& Sons, Ltd November 1, 2010, pp 1238-1249.

(55) Gierschik, P.; Milligan, G.; Pines, M.; Goldsmith, P.; Codina, J.; Klee, W.; Spiegel, A. Use of Specific Antibodies to Quantitate the Guanine Nucleotide-Binding Protein G(o) in Brain. Proc. Natl. Acad. Sci. U. S. A. 1986, 83 (7), 2258-2262.

(56) Sánchez-Blázquez, P.; Rodríguez-Díaz, M.; DeAntonio, I.; Garzón, J. Endomorphin-1 and Endomorphin-2 Show Differences in Their Activation of $\mu$ Opioid Receptor-Regulated $G$ Proteins in Supraspinal Antinociception in Mice. J. Pharmacol. Exp. Ther. 1999, 291 (1), $12-18$.

(57) Garzón, J.; García-España, A.; Sánchez-Blázquez, P. Opioids Binding Mu and Delta Receptors Exhibit Diverse Efficacy in the Activation of G(I2) and G(x/z) Transducer Proteins in Mouse Periaqueductal Gray Matter. J. Pharmacol. Exp. Ther. 1997, 281 (1), 549-557.

(58) Dahan, A. Opioid-Induced Respiratory Effects: New Data on Buprenorphine. Palliat. 
Med. 2006, 20 (SUPPL. 1), 3-8.

(59) Pergolizzi, J.; Aloisi, A. M.; Dahan, A.; Filitz, J.; Langford, R.; Likar, R.; Mercadante, S.; Morlion, B.; Raffa, R. B.; Sabatowski, R.; Sacerdote, P.; Torres, L. M.; Weinbroum, A. A. Current Knowledge of Buprenorphine and Its Unique Pharmacological Profile. Pain Pract. 2010, 10 (5), 428-450.

(60) Grinnell, S. G.; Ansonoff, M.; Marrone, G. F.; Lu, Z.; Narayan, A.; Xu, J.; Rossi, G.; Majumdar, S.; Pan, Y. X.; Bassoni, D. L.; Pintar, J.; Pasternak, G. W. Mediation of Buprenorphine Analgesia by a Combination of Traditional and Truncated Mu Opioid Receptor Splice Variants. Synapse 2016, 70 (10), 395-407.

(61) Canestrelli, C.; Marie, N.; Noble, F. Rewarding or Aversive Effects of Buprenorphine/Naloxone Combination (Suboxone) Depend on Conditioning Trial Duration. Int. J. Neuropsychopharmacol. 2014, 17 (09), 1367-1373.

(62) Selley, D. E.; Sim, L. J.; Xiao, R.; Liu, Q.; Childers, S. R. $\mu$-Opioid Receptor-Stimulated Guanosine-5'-O-( $\gamma$-Thio)-Triphosphate Binding in Rat Thalamus and Cultured Cell Lines: Signal Transduction Mechanisms Underlying Agonist Efficacy. Mol. Pharmacol. 1997, 51 (1), 87-96.

(63) Wnendt, S.; Krüger, T.; Janocha, E.; Hildebrandt, D.; Englberger, W. Agonistic Effect of Buprenorphine in a Nociceptin/OFQ Receptor-Triggered Reporter Gene Assay. Mol. Pharmacol. 1999, 56 (2), 334-338.

(64) Huang, P.; Kehner, G. B.; Cowan, A.; Liu-Chen, L. Y. Comparison of Pharmacological Activities of Buprenorphine and Norbuprenorphine: Norbuprenorphine Is a Potent Opioid Agonist. J. Pharmacol. Exp. Ther. 2001, 297 (2), 688-695.

(65) Alhaddad, H.; Cisternino, S.; Declèves, X.; Tournier, N.; Schlatter, J.; Chiadmi, F.; Risède, P.; Smirnova, M.; Besengez, C.; Scherrmann, J. M.; Baud, F. J.; Mégarbane, B. Respiratory Toxicity of Buprenorphine Results from the Blockage of P-GlycoproteinMediated Efflux of Norbuprenorphine at the Blood-Brain Barrier in Mice. Crit. Care Med. 2012, 40 (12), 3215-3223.

(66) Brown, S. M.; Holtzman, M.; Kim, T.; Kharasch, E. D. Buprenorphine Metabolites, Buprenorphine-3-Glucuronide and Norbuprenorphine-3-Glucuronide, Are Biologically Active. Anesthesiology 2011, 115 (6), 1251-1260.

(67) Iribarne, C.; Picart, D.; Dréano, Y.; Bail, J. P.; Berthou, F. Involvement of Cytochrome P450 3A4 in N-Dealkylation of Buprenorphine in Human Liver Microsomes. Life Sci. 1997, 60 (22), 1953-1964.

(68) Donthamsetti, P.; Quejada, J. R.; Javitch, J. A.; Gurevich, V. V.; Lambert, N. A. Using Bioluminescence Resonance Energy Transfer (BRET) to Characterize Agonist-Induced Arrestin Recruitment to Modified and Unmodified G Protein-Coupled Receptors. Curr. Protoc. Pharmacol. 2015, 70 (1), 2.14.1-2.14.14.

(69) Chiang, T.; Sansuk, K.; Van Rijn, R. M. $\beta$-Arrestin 2 Dependence of $\delta$ Opioid Receptor 
Agonists Is Correlated with Alcohol Intake. Br. J. Pharmacol. 2016, 173 (2), 332-343.

(70) Cassell, R. J.; Mores, K. L.; Zerfas, B. L.; Mahmoud, A. H.; Lill, M. A.; Trader, D. J.; van Rijn, R. M. Rubiscolins Are Naturally Occurring G Protein-Biased Delta Opioid Receptor Peptides. Eur. Neuropsychopharmacol. 2019, 29 (3), 450-456.

(71) Margolis, E. B.; Hjelmstad, G. O.; Fujita, W.; Fields, H. L. Direct Bidirectional $\mu$-Opioid Control of Midbrain Dopamine Neurons. J. Neurosci. 2014, 34 (44), 14707-14716.

(72) Eans, S. O.; Ganno, M. L.; Mizrachi, E.; Houghten, R. A.; Dooley, C. T.; McLaughlin, J. P.; Nefzi, A. Parallel Synthesis of Hexahydrodiimidazodiazepines Heterocyclic Peptidomimetics and Their in Vitro and in Vivo Activities at $\mu$ (MOR), $\delta$ (DOR), and $\kappa$ (KOR) Opioid Receptors. J. Med. Chem. 2015, 58 (12), 4905-4917.

(73) Zhou, Y.; Ramsey, S.; Provasi, D.; El Daibani, A.; Appourchaux, K.; Chakraborty, S.; Kapoor, A.; Che, T.; Majumdar, S.; Filizola, M. Predicted Mode of Binding to and Allosteric Modulation of the $\mu$-Opioid Receptor by Kratom's Alkaloids with Reported Antinociception in Vivo. Biochemistry 2020, in press.

(74) Clark, A. J.; Tiwary, P.; Borrelli, K.; Feng, S.; Miller, E. B.; Abel, R.; Friesner, R. A.; Berne, B. J. Prediction of Protein-Ligand Binding Poses via a Combination of Induced Fit Docking and Metadynamics Simulations. J. Chem. Theory Comput. 2016, 12 (6), 29902998.

(75) Frey, B. J.; Dueck, D. Clustering by Passing Messages between Data Points. Science (80-. ). 2007, 315 (5814), 972-976.

(76) Noé, F.; Schütte, C.; Vanden-Eijnden, E.; Reich, L.; Weikl, T. R. Constructing the Equilibrium Ensemble of Folding Pathways from Short Off-Equilibrium Simulations. Proc. Natl. Acad. Sci. U. S. A. 2009, 106 (45), 19011-19016.

(77) Stan Development Team. 2019. Stan Modeling Language Users Guide and Reference Manual, 2.21.0. https://mc-stan.org. 


\title{
Figure and Table legends
}

\author{
Figure 1. Chemistry
}

A) Structure of selected natural and synthetic analogs. B) Synthesis of C9 mitragynine and $70 H$ derivatives. C) Synthesis of $\mathrm{C10}$ mitragynine and $70 \mathrm{OH}$ derivatives. D) Synthesis of C12 mitragynine and $70 \mathrm{H}$ derivatives.

Reagents and conditions: (a) $\mathrm{AlCl}_{3}$, EtSH, DCM, $0{ }^{\circ} \mathrm{C}, 5 \mathrm{~h}$; (b) $\mathrm{PhNTf}_{2}, \mathrm{Et}_{3} \mathrm{~N}, \mathrm{DCM}, \mathrm{rt}, 12 \mathrm{~h}$; (c, yielding SC3) phenylboronic acid, $\mathrm{Pd}\left(\mathrm{PPh}_{3}\right)_{4}, \mathrm{~K}_{2} \mathrm{CO}_{3}, \mathrm{MeOH}$, toluene, $80{ }^{\circ} \mathrm{C}$, 8h; (d, yielding SC1) 3-furanylboronic acid, $\mathrm{Pd}\left(\mathrm{PPh}_{3}\right)_{4}, \mathrm{~K}_{2} \mathrm{CO}_{3}, \mathrm{MeOH}$, toluene, $80{ }^{\circ} \mathrm{C}$, 8h; (e, yielding SC4) DABAL-Me ${ }_{3}, \mathrm{Pd}_{2}(\mathrm{dba})_{3}, \mathrm{XPhos}$, THF, $60{ }^{\circ} \mathrm{C}$, 8h; (f, yielding SC11, SC13 and SC12) oxone ${ }^{\circledR}, \mathrm{NaHCO}_{3}, \mathrm{H}_{2} \mathrm{O}$, acetone, $0{ }^{\circ} \mathrm{C}, 1 \mathrm{~h}$. (g) ethylene glycol, PIFA, $\mathrm{CH}_{3} \mathrm{CN}, 0^{\circ} \mathrm{C}, 1 \mathrm{~h}$; (h) NBS, DMF, 5h, rt; (i) $\mathrm{NaBH}_{3} \mathrm{CN}, \mathrm{AcOH}, \mathrm{MeOH}$, reflux, 12h; (j, yielding SC21) phenylboronic acid, $\mathrm{Pd}(\mathrm{dppf}) \mathrm{Cl}_{2}, \mathrm{KOAc}, \mathrm{THF}, 70{ }^{\circ} \mathrm{C}$, 6h; (k, yielding SC22) 3furanylboronic acid, Pd(dppf)Cl ${ }_{2}, \mathrm{KOAc}$, THF, $70{ }^{\circ} \mathrm{C}$, 6h; (1, yielding SC23) DABAL-Me ${ }_{3}, \mathrm{Pd}_{2}(\mathrm{dba})_{3}$, XPhos, THF, $60{ }^{\circ} \mathrm{C}$, 8h; (m, yielding SC31, SC32 and SC33) oxone ${ }^{\circledR}, \mathrm{NaHCO}_{3}, \mathrm{H}_{2} \mathrm{O}$, acetone, $0{ }^{\circ} \mathrm{C}, 1 \mathrm{~h}$. (n) NBS, AcOH, 4h, rt; (o, yielding SC72) phenylboronic acid, $\mathrm{Pd}\left(\mathrm{PPh}_{3}\right)_{4}, \mathrm{~K}_{2} \mathrm{CO}_{3}, \mathrm{MeOH}$, toluene, $80{ }^{\circ} \mathrm{C}$, 8h; (p, yielding SC71) 3-furanylboronic acid, $\mathrm{Pd}\left(\mathrm{PPh}_{3}\right)_{4}, \mathrm{~K}_{2} \mathrm{CO}_{3}, \mathrm{MeOH}$, toluene, $80{ }^{\circ} \mathrm{C}$, 8h; (q, yielding SC73) DABAL-Me ${ }_{3}, \mathrm{Pd}_{2}(\mathrm{dba})_{3}$, XPhos, THF, $60{ }^{\circ} \mathrm{C}$, 8h; (r, yielding SC82, SC81 and SC83) oxone ${ }^{\circledR}$, $\mathrm{NaHCO}_{3}, \mathrm{H}_{2} \mathrm{O}$, acetone, $0{ }^{\circ} \mathrm{C}, 1 \mathrm{~h}$.

\section{Table 1. Functional studies at MOR using cAMP inhibition \& Tango-arrestin assays.}

${ }^{a}$ The functional data of each compound in cAMP and Tango $\beta$-arrestin2 in human mu-opioid receptor (hMOR) were determined and normalized to $\mathrm{E}_{\max }$ of the corresponding standard DAMGO. Results were analyzed using a three-parameter logistic equation in GraphPad Prism and the data are presented as mean $\mathrm{EC}_{50}\left(\mathrm{pEC}_{50} \pm \mathrm{SEM}\right)$ with $\mathrm{E}_{\max } \% \pm \mathrm{SEM}$ for assays run in triplicate. nd; results could not be determined because efficacy of $\beta$-arrestin2 recruitment was less than $20 \%$.

Figure 2. G-protein signaling, arrestin signaling, whole cell electrophysiology in rat VTA and Ga-subtype screening of SC 11-13 and MOR controls in hMOR. SC11-13 are MOR partial agonists in cell based assays G-protein signaling assays as well as in ephys assays. 
A) SC 11-13 are MOR partial agonists with lower efficacy than morphine, fentanyl and DAMGO in Gi-1 BRET assays. B) SC11-13 showed no measurable $\beta$-arrestin2 recruitment $(<10 \%)$ in BRET arrestin recruitment assays compared to fentanyl and DAMGO in this assay. C) In Nb33 recruitment assays measured using BRET assays in hMOR, SC13 had lower efficacy than DAMGO and morphine and similar efficacy to buprenorphine. D) In Nb33 recruitment assays measured using BRET assays in mMOR, SC13 had lower efficacy than DAMGO and morphine and similar efficacy to buprenorphine. E) Summary inhibition of electrically evoked IPSCs in VTA neurons in response to $5 \mu \mathrm{M}$ DAMGO, $10 \mu \mathrm{M}$ morphine, $10 \mu \mathrm{M}$ SC11, $10 \mu \mathrm{M} \mathrm{SC12}, 10 \mu \mathrm{M} \mathrm{SC13}$, where each circle is one neuron. Horizontal bars indicate means. SC 11-13 show lower efficacy than DAMGO. F) Mean time course of responses during bath application of SC13, $\mathrm{n}=8$ in whole cell electrophysiology in rat VTA. See Appendix 1- Table 3 in SI for values for panels A-D. G) TRUPATH heatmaps demonstrate how a panel of kratom analogs, SC11-13 and MOR agonists engage Gai/o-class transducers with varying potency $(\mathbf{G})$ and efficacy $(\mathbf{H})$. Most ligands exhibit enhanced $(\mathrm{G} \alpha \mathrm{Z})$ relative to other G-protein transducers. Heatmap colors represent mean $\log \left(\mathrm{EC}_{50}\right)$ and normalized efficacy values; NR, no response, presented as a white square. Mean values and standard error are reported in Appendix 1-Table 4. Data for all functional assays were carried out in hMOR was normalized to $\mathrm{E}_{\max }$ of DAMGO. The dose response curves were fit using a three-parameter logistic equation in GraphPad Prism and the data are presented as mean $\mathrm{EC}_{50}\left(\mathrm{pEC}_{50} \pm \mathrm{SEM}\right)$ for assays run in triplicate.

Figure 3. SC13 shows MOR dependent antinociception and lacks abuse potential, constipation, respiratory depression and hyperlocomotion at equianalgesic morphine doses.

A) Antinociception time course: Groups of C57BL/6J mice were subcutaneously ( $s c$ administered SC13 and antinociception measured using the $55^{\circ} \mathrm{C}$ tail withdrawal assay. Data are shown as mean $\%$ antinociception \pm SEM. (A) Effect of SC13 at doses of 1, 3 and $10 \mathrm{mg} / \mathrm{kg}$ ( $n=8$ each group) with repeated measures over time. SC13 showed potent dose dependent antinociception.

B) SC13 antinociception in KO mice: Antinociception effect of SC13 (10 mg/kg, $s c$, ) was evaluated in group of $(\mathrm{n}=8)$ in WT, MOR KO, KOR KO, and DOR KO mice. Antinociception of $\mathbf{S C 1 3}$ remained intact 
in DOR KO (p=0.13) and KOR KO (p=0.058) mice while it was found attenuated in MOR KO. Results for SC13 were analyzed with one-way ANOVA followed by Tukey's post-hoc test, $\mathrm{F}_{3,28}=24.07, \mathrm{p}<0.0001$, $* * * * \mathrm{p}<0.0001$ relative to WT, $\mathrm{ns}=\mathrm{p}>0.05$ relative to WT. Attenuation of $\mathbf{S C 1 3}$ antinociception in MOR KO was also significantly greater compared to DOR KO and KOR KO mice ( $p<0.0001$ each; Tukey's post hoc test). All values are expressed as the mean \pm SEM.

C) Conditioned place preference or aversion (CPP/CPA): Place conditioning evaluation of SC13, morphine, U50,488H, in C57BL/6J mice after IP or sc administration. Following determination of initial preconditioning preferences, mice were place-conditioned daily for 2 days with $\mathbf{S C 1 3}(15 \mathrm{mg} / \mathrm{kg}, s c$; $\mathrm{n}=31), \mathrm{U} 50,488 \mathrm{H}(30 \mathrm{mg} / \mathrm{kg}, I P ; \mathrm{n}=28)$ or morphine $(10 \mathrm{mg} / \mathrm{kg}, I P ; \mathrm{n}=18)$. Mean differences in time spent on the drug-paired side \pm SEM are presented. SC13 does not display significant CPP or CPA compared to the matching preconditioning preference $(\mathrm{p}<0.05)$, as determined by unpaired $\mathrm{t}$-test with Welch's correction. Morphine showed CPP $\left({ }^{*} \mathrm{p}=0.0140\right)$ and $\mathrm{U} 50,488 \mathrm{H}$ showed CPA $(* * * * \mathrm{p}<0.0001)$ and were significantly different from matching preconditioning preference.

D) SC 13 effects on Gastrointestinal Transit. Mice were administered morphine (10 mg/kg, sc) or SC13 $(15 \mathrm{mg} / \mathrm{kg}, \mathrm{sc})$ or saline $(0.9 \%$, po), then fed a charcoal meal. After 3h, morphine significantly reduced the distance traveled by the charcoal through the intestines, consistent with the action of a MOR agonist $(5.07 \pm 0.57 \mathrm{~cm}$, compared to $29.5 \pm 1 \mathrm{~cm}$ for saline-treated mice; $\mathrm{F}(2,21)=81.88, \mathrm{P}<0.0001$; oneway ANOVA with Dunnett's multiple-comparison test. In contrast, compound SC13 was without significant effect $(30.8 \pm 2.52 \mathrm{~cm})$.

E) Respiratory rate: Mice were administered either vehicle ( $\mathrm{n}=12)$, morphine (30 mg/kg, $s c ; \mathrm{n}=12)$, SC13 (45 $\mathrm{mg} / \mathrm{kg}, s c ; \mathrm{n}=12)$ and the breath rates was measured every $20 \mathrm{~min}$ for 180 minutes. Morphine administered $s c$ caused reduction in the breath rate with respect to saline at $20 \min (* * \mathrm{p}=0.0021), 40 \mathrm{~min}$ $(* * * \mathrm{p}=0.0003)$ and $60 \mathrm{~min}(* * \mathrm{p}=0.0010)$ post drug administration. SC13 $(45 \mathrm{mg} / \mathrm{kg}$, sc) was not significantly different from vehicle control except at $180 \min (* * * * p<0.0001)$ and $200 \min (* \mathrm{p}=0.0410)$ where it showed an increase in breath rates as determined by 2-way ANOVA followed by Dunnett's multiple-comparison test. 
F) Locomotor effect: Mice were administered either saline $(n=20)$, vehicle $(n=24)$, morphine $(10$ and 30 $\mathrm{mg} / \mathrm{kg}, s c ; \mathrm{n}=12 \mathrm{each})$, and $\mathbf{S C 1 3}$ (45 mg/kg, sc; $\mathrm{n}=12)$ and the distance travelled by each group of mice was measured. No significant locomotory effects were observed with SC13 as determined by 2-way ANOVA followed by Dunnett's multiple-comparison test in comparsion to vehicle while morphine showed significant hyperlocomotion at every time point compared to saline $(\mathrm{p}<0.0001)$.

G) Oral antinociceptive time course: Groups of C57BL/6J mice were orally ( $p o$ ) administered SC13 at $10 \mathrm{mg} / \mathrm{kg}$ and antinociception measured using the $55^{\circ} \mathrm{C}$ tail withdrawal assay. SC13 showed antinociception with $80 \%$ MPE at peak time point. Data are shown as mean $\%$ antinociception \pm SEM. Effect of SC13 at dose $10 \mathrm{mg} / \mathrm{kg}(n=8)$ with repeated measures over time. 

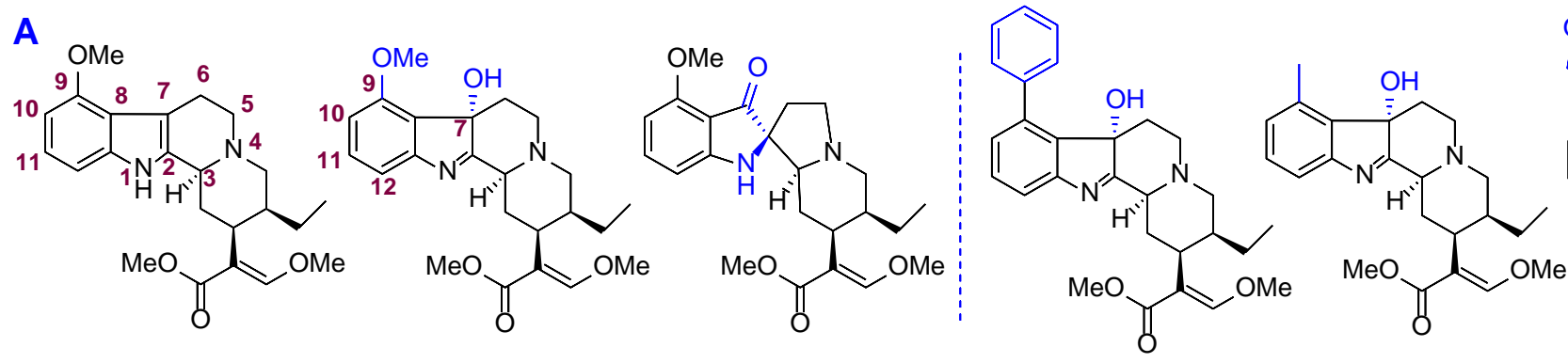

SC11

SC12 SC13
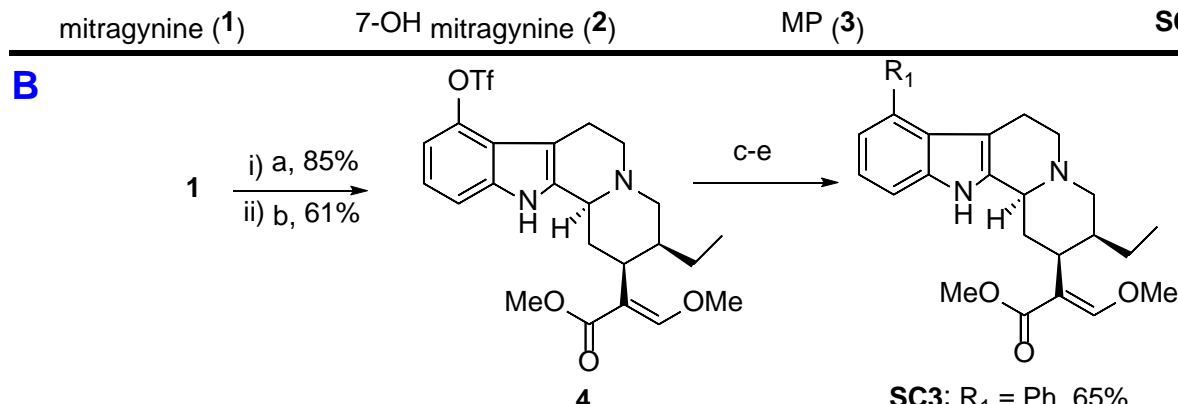

SC3: $R_{1}=P h, 65 \%$

SC1: $R_{1}=$ furan-3-yl, $73 \%$

SC4: $R_{1}=\mathrm{Me}, 68 \%$

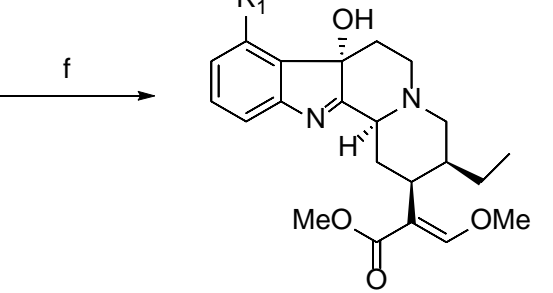

SC3 $\longrightarrow$ SC11: $R_{1}=P h, 33 \%$

$S C 1 \longrightarrow$ SC13: $R_{1}=$ furan-3-yl, $38 \%$

SC4 $\longrightarrow$ SC12: $\mathrm{R}_{1}=\mathrm{Me}, 42 \%$

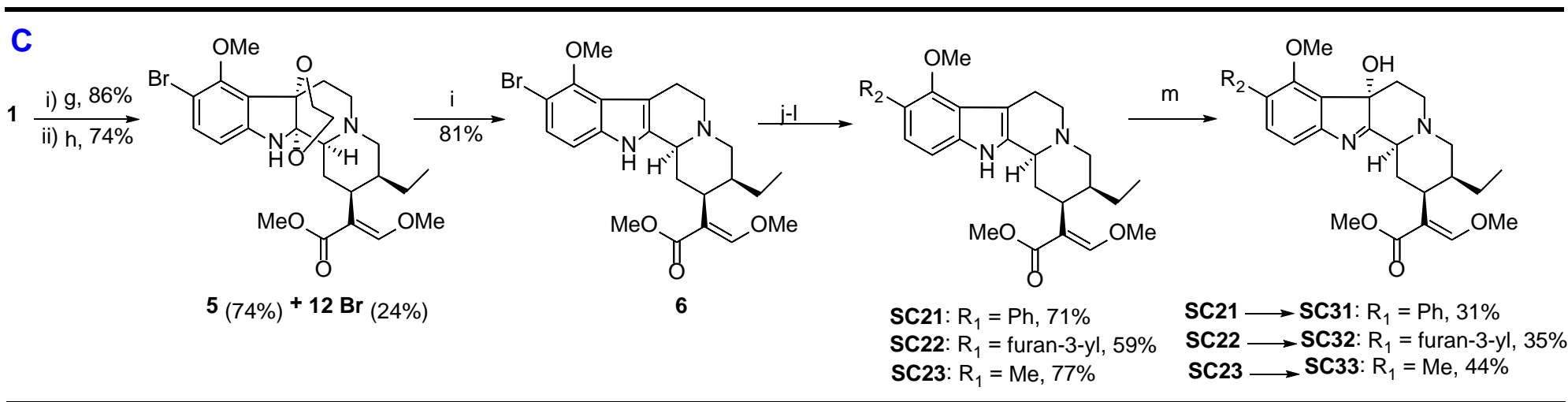

D

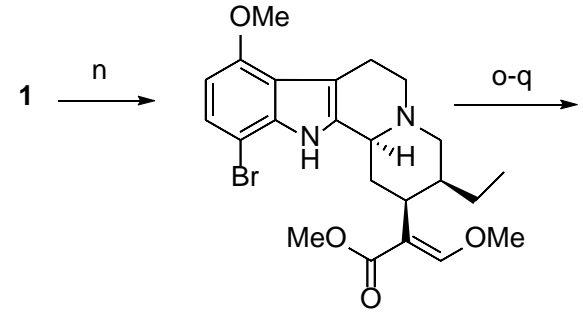

$\mathrm{OMe}$

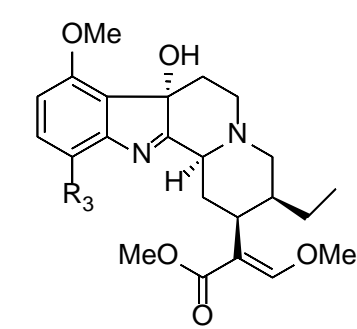

$7(47 \%)+10 \mathrm{Br}(4 \%)$

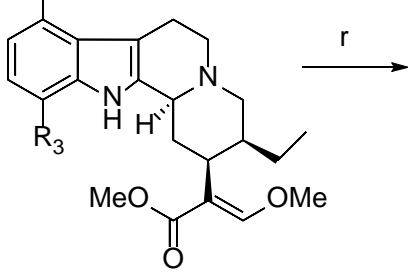

SC72: $R_{1}=P h, 67 \%$ SC71: $R_{1}=$ furan-3-yl, $69 \%$ SC73: $R_{1}=M e, 87 \%$

SC72 $\longrightarrow$ SC82: $\mathrm{R}_{1}=\mathrm{Ph}, 41 \%$

SC71 $\longrightarrow$ SC81: $R_{1}=$ furan-3-yl, $45 \%$

SC73 $\longrightarrow$ SC83: $R_{1}=$ Me, $55 \%$ 
Table 1. Functional studies at MOR using cAMP inhibition \& Tango-arrestin assays.

\begin{tabular}{|c|c|c|c|c|}
\hline \multicolumn{5}{|c|}{ Functional data at MOR using cAMP inhibition \& Tango-arrestin assays ${ }^{\mathrm{a}}$} \\
\hline \multirow[t]{2}{*}{ Compd. } & \multicolumn{2}{|c|}{ cAMP inhibition } & \multicolumn{2}{|c|}{$\beta$-arrestin2 recruitment } \\
\hline & $\mathrm{EC}_{50} \mathrm{nM}\left(\mathrm{pEC}_{50} \pm \mathrm{SEM}\right)$ & Emax\% \pm SEM & $\mathrm{EC}_{50} \mathrm{nM}\left(\mathrm{pEC}_{50} \pm \mathrm{SEM}\right)$ & Emax\% $\%$ SEM \\
\hline SC1 & $93.73(7.03 \pm 0.15)$ & $70.24 \pm 4.56$ & 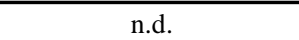 & $<20$ \\
\hline SC3 & $83.16(7.08 \pm 0.17)$ & $46.13 \pm 3.81$ & n.d. & $<20$ \\
\hline SC4 & $82.94(7.08 \pm 0.08)$ & $97.08 \pm 3.52$ & n.d. & $<20$ \\
\hline SC11 & $36.20(7.44 \pm 0.06)$ & $107.9 \pm 2.76$ & $19200(4.72 \pm 0.17)$ & $283 \pm 34$ \\
\hline SC12 & $5.25(8.28 \pm 0.06)$ & $108.0 \pm 1.92$ & $10400(4.98 \pm 0.15)$ & $110 \pm 2$ \\
\hline SC13 & $7.25(8.14 \pm 0.05)$ & $105.61 \pm 1.59$ & $11000(4.96 \pm 0.22)$ & $45 \pm 4$ \\
\hline SC21 & $3763(5.42 \pm 0.15)$ & $73.88 \pm 0.75$ & n.d. & $<20$ \\
\hline SC22 & $85.92(7.07 \pm 0.07)$ & $90.82 \pm 3.02$ & n.d. & $<20$ \\
\hline SC23 & $369.7(6.43 \pm 0.09)$ & $96.51 \pm 4.05$ & n.d. & $<20$ \\
\hline SC31 & $104.3(6.98 \pm 0.07)$ & $88.73 \pm 2.81$ & n.d. & $<20$ \\
\hline SC32 & $534.7(6.27 \pm 0.07)$ & $100.34 \pm 3.30$ & $8039(5.09 \pm 0.45)$ & $31.34 \pm 16.72$ \\
\hline SC33 & $30.25(7.52 \pm 0.09)$ & $99.58 \pm 2.75$ & n.d. & $<20$ \\
\hline SC71 & $186.2(6.73 \pm 0.08)$ & $78.22 \pm 3.39$ & n.d. & $<20$ \\
\hline SC72 & $1113(5.95 \pm 0.19)$ & $50.35 \pm 7.27$ & n.d. & $<20$ \\
\hline SC73 & $71.44(7.15 \pm 0.06)$ & $83.86 \pm 2.76$ & n.d. & $<20$ \\
\hline SC81 & $1560(5.81 \pm 0.14)$ & $61.81 \pm 6.52$ & n.d. & $<20$ \\
\hline SC82 & $17510(4.76 \pm 0.78)$ & $17 \pm 3$ & n.d. & $<20$ \\
\hline SC83 & $11.24(7.95 \pm 0.06)$ & $69.34 \pm 1.63$ & n.d. & $<20$ \\
\hline Mitragynine & $241.2(6.62 \pm 0.10)$ & $84.68 \pm 3.44$ & n.d. & $<20$ \\
\hline $70 \mathrm{H}$ & $5.93(8.23 \pm 0.06)$ & $95.55 \pm 1.79$ & n.d. & $<20$ \\
\hline DAMGO & $0.49(9.31 \pm 0.05)$ & 100 & $182.04(6.74 \pm 0.09)$ & 100 \\
\hline
\end{tabular}

\section{Table 1}


A sc antinociception

C

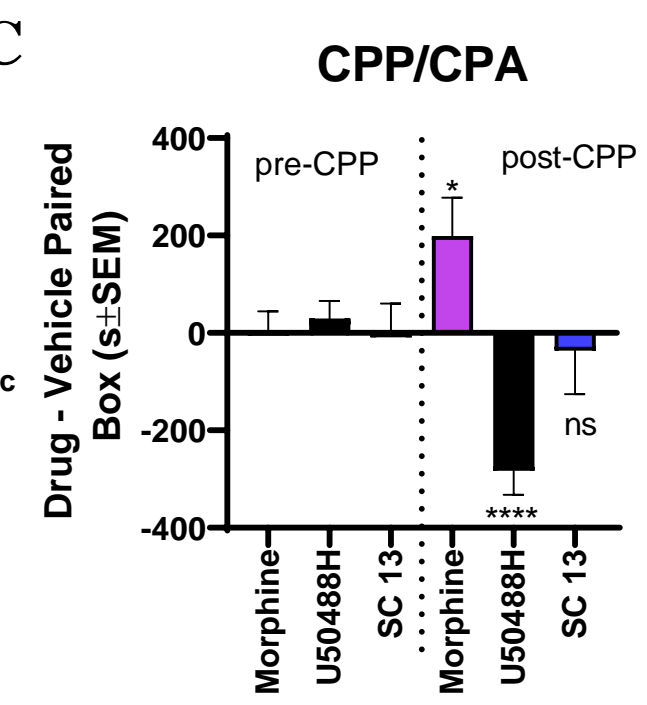

B KO mice sc antinociception

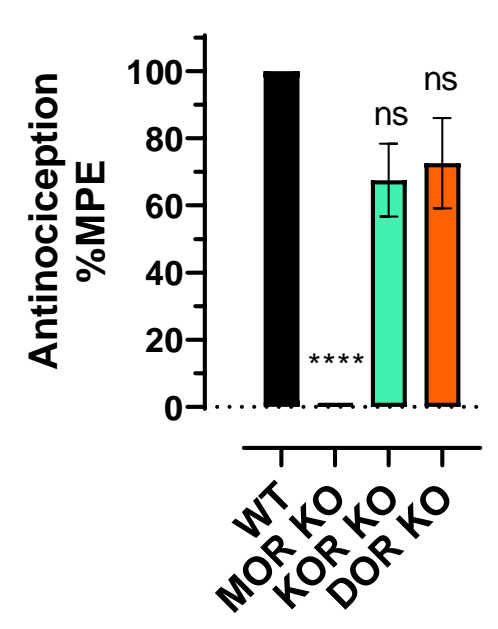

D Gl transit

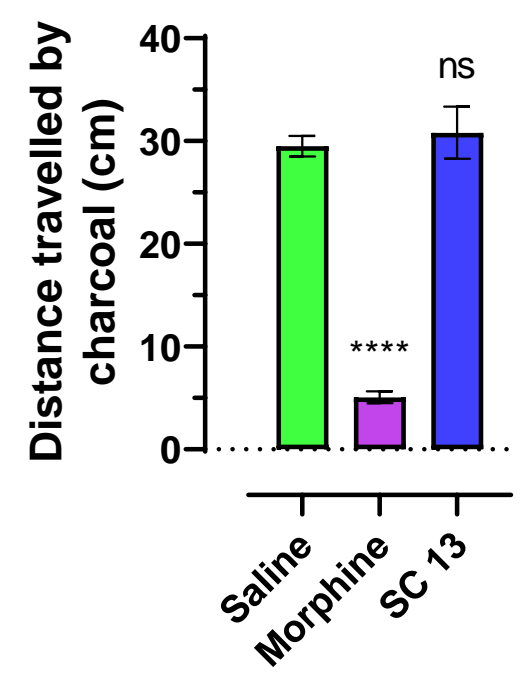

E

\section{Respiration}

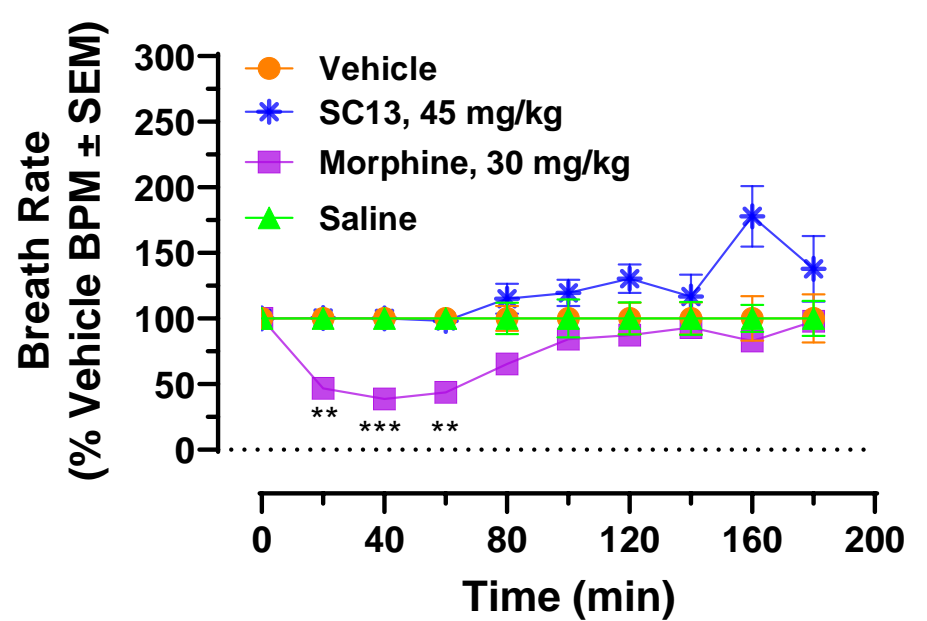

$\mathbf{F}$

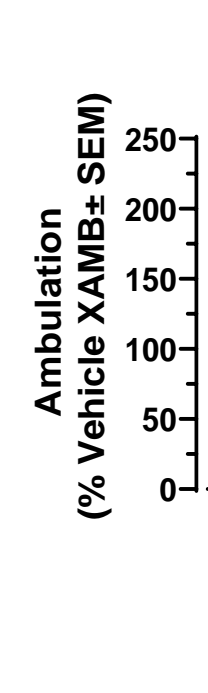

\section{Locomotor}

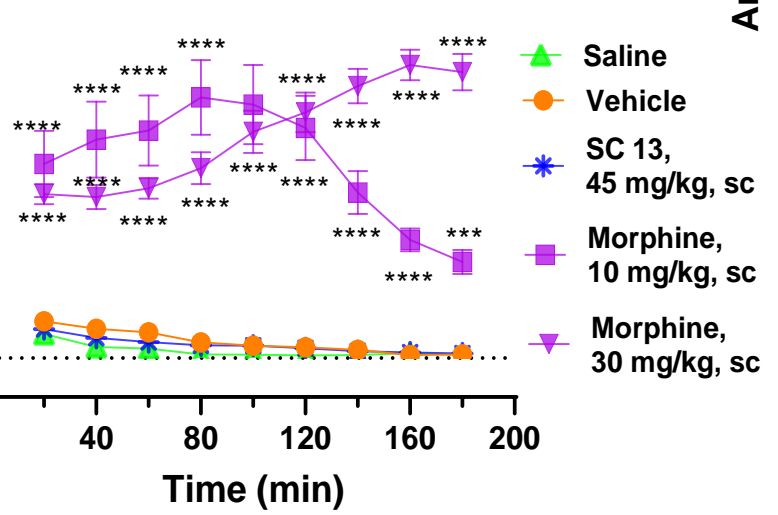

\section{G}

Oral antinociception

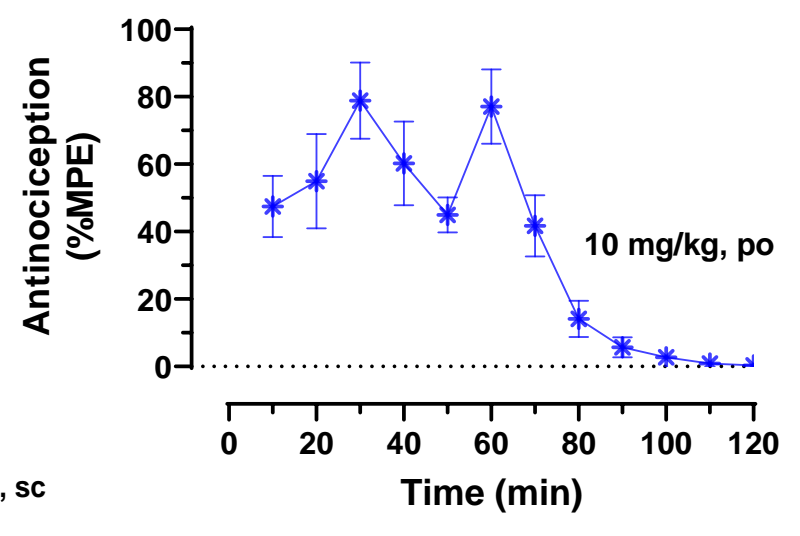

\section{Figure 3}




\section{A novel mitragynine analog with low efficacy mu-opioid receptor agonism displays antinociception with attenuated adverse effects}

Soumen Chakraborty ${ }^{\mathrm{a}, \mathrm{b}}$, Jeffrey F. DiBerto ${ }^{\mathrm{c}}$, Abdelfattah Faouzi ${ }^{\mathrm{a}, \mathrm{b}}$, Sarah M. Bernhard ${ }^{\mathrm{a}, \mathrm{b}}$, Anna M. Gutridge $^{\mathrm{d}}$, Steven Ramsey ${ }^{\mathrm{e}}$, Yuchen Zhou ${ }^{\mathrm{e}}$, Davide Provasi ${ }^{\mathrm{e}}$, Nitin Nuthikattu ${ }^{\mathrm{a}, \mathrm{b}}$, Rahul Jilakara ${ }^{\mathrm{a}, \mathrm{b}}$, Melissa N.F. Nelson ${ }^{f}$, Wesley B. Asher ${ }^{f}$, Shainnel O. Eans ${ }^{g}$, Lisa L. Wilson ${ }^{g}$, Satyanarayana M Chintala ${ }^{b}$, Marta Filizola ${ }^{\mathrm{e}}$, Richard M. van Rijn ${ }^{\mathrm{d}}$, Elyssa B. Margolis ${ }^{\mathrm{h}}$, Bryan L. Roth ${ }^{\mathrm{c}}$, Jay P. McLaughling, Tao Che ${ }^{\mathrm{a}, \mathrm{b}, \mathrm{c}}$, Dalibor Sames ${ }^{\mathrm{i}}$, Jonathan A. Javitch ${ }^{\mathrm{f}}$, and Susruta Majumdar ${ }^{\mathrm{a}, \mathrm{b},{ }^{*}}$

${ }^{a}$ Center for Clinical Pharmacology, University of Health Sciences \& Pharmacy at St. Louis and Washington University School of Medicine, St. Louis, MO 63110, USA.

b Department of Anesthesiology, Washington University School of Medicine, St Louis, MO 63110, USA.

'Department of Pharmacology, University of North Carolina at Chapel Hill School of Medicine, Chapel Hill, NC 27599, USA.

${ }^{\mathrm{d} D e p a r t m e n t}$ of Medicinal Chemistry and Molecular Pharmacology, College of Pharmacy, Purdue University, West Lafayette, IA 47907, USA

e Department of Pharmacological Sciences, Icahn School of Medicine at Mount Sinai, New York, NY 10029, USA.

${ }^{\mathrm{f}}$ Departments of Psychiatry and Molecular Pharmacology and Therapeutics, Columbia University Vagelos College of Physicians and Surgeons, and Division of Molecular Therapeutics, New York State Psychiatric Institute, New York, NY 10032, USA.

'Department of Pharmacodynamics, University of Florida, Gainesville, FL 032610, USA.

hepartment of Neurology, UCSF Weill Institute for Neurosciences, University of California San Francisco, San Francisco, California 94158, USA.

iDepartment of Chemistry, Columbia University, NY 10027, USA.

\section{Corresponding author(s)}

Jonathan A. Javitch, MD PhD

Email: jaj2@cumc.columbia.edu

Tel No: 914-484-8668

and

Susruta Majumdar, PhD

Email:susrutam@email.wustl.edu

Tel no: 314-446-8162 


\section{Appendix 1}

Appendix 1-Table 1. Functional studies at KOR using cAMP inhibition \& Tango-arrestin assays.

\begin{tabular}{|c|c|c|c|c|}
\hline \multicolumn{5}{|c|}{ Functional data at KOR using cAMP inhibition $\&$ Tango-arrestin assays ${ }^{\mathrm{a}}$} \\
\hline \multirow[t]{2}{*}{ Compd. } & \multicolumn{2}{|c|}{ cAMP inhibition } & \multicolumn{2}{|c|}{$\beta$-arrestin2 recruitment } \\
\hline & $\mathrm{EC}_{50} \mathrm{nM}(\mathrm{pEC} 50 \pm \mathrm{SEM})$ & Emax\% \pm SEM & $\mathrm{EC}_{50} \mathrm{nM}(\mathrm{pEC} 50 \pm \mathrm{SEM})$ & Emax\% \pm SEM \\
\hline SC1 & $10.71(7.97 \pm 0.11)$ & $86.37 \pm 2.66$ & n.d. & $<20$ \\
\hline SC3 & $52.92(7.28 \pm 0.12)$ & $83.46 \pm 3.31$ & n.d. & $<20$ \\
\hline SC4 & $63.27(7.20 \pm 0.09)$ & $93.61 \pm 3.39$ & n.d. & $<20$ \\
\hline SC11 & $709.1(6.15 \pm 0.11)$ & $91.7 \pm 5.02$ & n.d. & $<20$ \\
\hline SC12 & $26.73(7.57 \pm 0.09$ & $97.75 \pm 2.57$ & n.d. & $<20$ \\
\hline SC13 & $213.2(6.67 \pm 0.08)$ & $92.29 \pm 2.82$ & n.d. & $<20$ \\
\hline SC21 & $4974(5.30 \pm 0.19)$ & $61.1 \pm 4.6$ & n.d. & $<20$ \\
\hline SC22 & $98.09(7.01 \pm 0.10)$ & $101.08 \pm 3.89$ & n.d. & $<20$ \\
\hline SC23 & $72.90(7.14 \pm 0.12)$ & $99.28 \pm 3.98$ & n.d. & $<20$ \\
\hline SC31 & $2484(5.60 \pm 0.21)$ & $49.33 \pm 4.53$ & n.d. & $24.83 \pm 3.84$ \\
\hline SC32 & $7822(5.11 \pm 0.13)$ & $96.2 \pm 1.2$ & n.d. & $<20$ \\
\hline SC33 & $86.32(7.06 \pm 0.08)$ & $89.70 \pm 2.36$ & n.d. & $<20$ \\
\hline SC71 & $48.38(7.31 \pm 0.10)$ & $82.86 \pm 3.28$ & n.d. & $<20$ \\
\hline SC72 & $42.69(7.37 \pm 0.09)$ & $78.76 \pm 2.28$ & n.d. & $<20$ \\
\hline SC73 & $1289(5.89 \pm 0.18)$ & $61.88 \pm 7.07$ & n.d. & $<20$ \\
\hline SC81 & $127.4(6.89 \pm 0.09)$ & $72.30 \pm 2.58$ & n.d. & $<20$ \\
\hline SC82 & $4184(5.38 \pm 0.21)$ & $56.39 \pm 3.00$ & n.d. & $<20$ \\
\hline SC83 & $22.67(7.64 \pm 0.097)$ & $65.30 \pm 2.11$ & n.d. & $<20$ \\
\hline Mitragynine & $68.76(7.16 \pm 0.21)$ & $57.01 \pm 3.93$ & n.d. & $<20$ \\
\hline $70 H$ & $25.41(7.59 \pm 0.05)$ & $90.84 \pm 1.43$ & $2911(5.54 \pm 0.43)$ & $36.79 \pm 13.15$ \\
\hline U50488H & $0.005(10.29 \pm 0.06)$ & 100 & $7.85(8.10 \pm 0.10)$ & 100 \\
\hline
\end{tabular}

aThe functional data of each assay using human kappa opioid receptor (hKOR) was normalized to Emax of corresponding standard U50488H.

Results were analyzed using a three-parameter logistic equation in GraphPad Prism and the data are presented as mean EC 50 (pEC50 \pm SEM) with $\mathrm{E}_{\max } \% \pm \mathrm{SEM}$ for assays run in triplicate; nd; results could not be determined because of efficacy of $\beta$-arrestin2 recruitment was less than $20 \%$ and/or shallow slopes. 
Appendix 1-Table 2. Functional studies at DOR using cAMP inhibition \& Tango-arrestin assays.

\begin{tabular}{|c|c|c|c|c|}
\hline \multicolumn{5}{|c|}{ Functional data at DOR using cAMP inhibition \& Tango-arrestin assays ${ }^{\mathrm{a}}$} \\
\hline \multirow[t]{2}{*}{ Compd. } & \multicolumn{2}{|c|}{ cAMP inhibition } & \multicolumn{2}{|c|}{$\beta$-arrestin2 recruitment } \\
\hline & $\mathrm{EC}_{50} \mathrm{nM}(\mathrm{pEC} 50 \pm \mathrm{SEM})$ & Emax\% \pm SEM & $\mathrm{EC}_{50} \mathrm{nM}\left(\mathrm{pEC}_{50} \pm \mathrm{SEM}\right)$ & Emax\% \pm SEM \\
\hline SC1 & $571.9(6.24 \pm 0.07)$ & $115.37 \pm 5.21$ & $308.1(6.51 \pm 0.21)$ & $53.82 \pm 4.43$ \\
\hline SC3 & $871.1(6.06 \pm 0.08)$ & $85.53 \pm 5.37$ & $243.8(6.61 \pm 0.34)$ & $46.88 \pm 5.69$ \\
\hline SC4 & $2640(5.58 \pm 0.07)$ & $114.00 \pm 20.9$ & $503.8(6.3 \pm 0.26)$ & $50.55 \pm 5.7$ \\
\hline SC11 & $85.89(7.07 \pm 0.10)$ & $111.79 \pm 5.97$ & $260.8(6.58 \pm 0.06)$ & $293.93 \pm 7.65$ \\
\hline SC12 & $152.6(6.82 \pm 0.10)$ & $98.09 \pm 5.45$ & $1120(5.95 \pm 0.10)$ & $211.34 \pm 12.57$ \\
\hline SC13 & $97.6(7.01 \pm 0.10)$ & $103.15 \pm 5.27$ & $660(6.18 \pm 0.10)$ & $191.03 \pm 10.56$ \\
\hline SC21 & n.d & $79 \pm 1$ & n.d & $<20$ \\
\hline SC22 & $1650(5.78 \pm 0.10)$ & $99.15 \pm 7.74$ & n.d & $<20$ \\
\hline SC23 & $2179(5.66 \pm 0.12)$ & $116.22 \pm 10.3$ & $982.2(6.01 \pm 0.2)$ & $65.04 \pm 7.32$ \\
\hline SC31 & $176.4(6.75 \pm 0.08)$ & $106.25 \pm 3.21$ & $160.0(6.8 \pm 0.08)$ & $129.52 \pm 4.86$ \\
\hline SC32 & $4279(5.37 \pm 0.09)$ & $105.87 \pm 3.04$ & n.d & $<20$ \\
\hline SC33 & $159.2(6.80 \pm 0.09)$ & $100.49 \pm 4.21$ & $461.7(6.34 \pm 0.1)$ & $168.77 \pm 8.85$ \\
\hline SC71 & $2817(5.55 \pm 0.19)$ & $70.42 \pm 3.57$ & n.d. & $<20$ \\
\hline SC72 & n.d. & $39.03 \pm 3.17$ & n.d. & $<20$ \\
\hline SC73 & $2349(5.63 \pm 0.13)$ & $78.35 \pm 4.37$ & n.d. & $<20$ \\
\hline SC81 & $4082(5.39 \pm 0.27)$ & $86.7 \pm 21.92$ & n.d & $53.14 \pm 16.41$ \\
\hline SC82 & n.d. & $50 \pm 4.8$ & $2681(5.57 \pm 0.17)$ & $81 \pm 13$ \\
\hline SC83 & $144.6(6.84 \pm 0.10)$ & $74.92 \pm 2.73$ & $729.8(6.14 \pm 0.19)$ & $70.01 \pm 8.49$ \\
\hline Mitragynine & $1179(5.93 \pm 0.11)$ & $112.43 \pm 7.75$ & $559.3(6.25 \pm 0.25)$ & $46.83 \pm 6.11$ \\
\hline $70 H$ & $97.83(7.01 \pm 0.08)$ & $91.60 \pm 3.72$ & $732.4(6.13 \pm 0.06)$ & $191.39 \pm 6.47$ \\
\hline DPDPE & $2.11(8.68 \pm 0.07)$ & 100 & $6.91(8.16 \pm 0.10)$ & 100 \\
\hline
\end{tabular}

a The functional data of each assay using human delta opioid receptor (hDOR) was normalized to Emax of corresponding standards DPDPE. Results were analyzed using a three-parameter logistic equation in GraphPad Prism and the data are presented as mean EC50 (pEC50 \pm SEM) with $\mathrm{Emax}_{\mathrm{m}} \% \pm \mathrm{SEM}$ for assays run in triplicate; nd; results could not be determined because of efficacy of $\beta$-arrestin2 recruitment was less than $20 \%$ and/or shallow slopes. 
Appendix 1-Table 3. Functional binding data of the compounds at opioid receptors (hMOR/mMOR).

\begin{tabular}{|c|c|c|c|c|c|c|}
\hline \multirow[t]{3}{*}{ Receptors } & \multirow[t]{2}{*}{ Compounds } & \multicolumn{2}{|c|}{ G protein activation (BRET) assay } & \multicolumn{2}{|c|}{ Arrestin recruitment (BRET) assay } & \multirow[t]{2}{*}{ Figure } \\
\hline & & $\mathrm{EC}_{50} \mathrm{nM}\left(\mathrm{pEC}_{50} \pm \mathrm{SEM}\right)$ & $\mathrm{Emax} \% \pm \mathrm{SEM}$ & $\mathrm{EC}_{50} \mathrm{nM}\left(\mathrm{pEC}_{50} \pm \mathrm{SEM}\right)$ & Emax\% \pm SEM & \\
\hline & SC11 & $1250(5.90 \pm 0.14)$ & $60.50 \pm 5.15$ & nd & nd & 2A-B \\
\hline \multirow[t]{3}{*}{ hMOR } & SC12 & $252.79(6.6 \pm 0.15)$ & $61.76 \pm 4.05$ & nd & nd & 2A-B \\
\hline & SC13 & $145.13(6.84 \pm 0.08)$ & $69.65 \pm 2.61$ & nd & nd & 2A-B \\
\hline & DAMGO & $17.35(7.76 \pm 0.09)$ & 100 & $161.33(6.79 \pm 0.06)$ & 100 & 2A-B \\
\hline \multirow[t]{3}{*}{ Receptors } & Controls & \multicolumn{2}{|c|}{ G protein activation (BRET) assay } & \multicolumn{2}{|c|}{ Arrestin recruitment (BRET) assay } & Figure \\
\hline & & $\mathrm{EC}_{50} \mathrm{nM}\left(\mathrm{pEC}_{50} \pm \mathrm{SEM}\right)$ & $\mathrm{Emax} \% \pm \mathrm{SEM}$ & $\mathrm{EC}_{50} \mathrm{nM}\left(\mathrm{pEC}_{50} \pm \mathrm{SEM}\right)$ & Emax $\% \pm$ SEM & \\
\hline & Buprenorphine & $0.42(9.38 \pm 0.24)$ & $43.63 \pm 2.36$ & nd & nd & S1E-F \\
\hline \multirow[t]{3}{*}{ hMOR } & Morphine & $81.34(7.09 \pm 0.12)$ & $97.21 \pm 4.36$ & $6774.6(5.17 \pm 0.64)$ & $32.59 \pm 10.55$ & S1E-F \\
\hline & Fentanyl & $13.17(7.88 \pm 0.18)$ & $122.45 \pm 9.11$ & $118.64(6.93 \pm 0.13)$ & $97.93 \pm 4.17$ & S1E-F \\
\hline & DAMGO & $12.58(7.9 \pm 0.07)$ & 100 & $175(6.76 \pm 0.08)$ & 100 & S1E-F \\
\hline \multirow[t]{6}{*}{ Receptors } & Compounds & \multicolumn{2}{|c|}{ Nb33 recruitment assay (hMOR) } & \multicolumn{2}{|c|}{ Nb33 recruitment assay (mMOR) } & Figure \\
\hline & & $\mathrm{EC}_{50} \mathrm{nM}\left(\mathrm{pEC}_{50} \pm \mathrm{SEM}\right)$ & Emax\% \pm SEM & $\mathrm{EC}_{50} \mathrm{nM}\left(\mathrm{pEC}_{50} \pm \mathrm{SEM}\right)$ & Emax\% \pm SEM & \\
\hline & DAMGO & $265.45(6.58 \pm 0.05)$ & $100 \pm 2.17$ & $154.25(6.81 \pm 0.04)$ & $100 \pm 1.50$ & 2C-D \\
\hline & Buprenorphine & $3.25(8.49 \pm 0.31)$ & $23.83 \pm 1.89$ & $3.65(8.44 \pm 0.34)$ & $20.55 \pm 1.62$ & 2C-D \\
\hline & Morphine & $1600(5.78 \pm 0.17)$ & $71.86 \pm 4.79$ & $584.83(6.23 \pm 0.09)$ & $69.62 \pm 2.44$ & 2C-D \\
\hline & SC13 & $730.53(6.14 \pm 0.21)$ & $21.13 \pm 2.23$ & $12.27(7.91 \pm 0.40)$ & $7.69 \pm 1.1$ & 2C-D \\
\hline
\end{tabular}

The functional data of each assay using human/mouse mu opioid receptor (hMOR/mMOR) were normalized to Emax of corresponding standards. Results were analyzed using a three-parameter logistic equation in GraphPad Prism and the data are presented as mean EC50 (pEC50 \pm SEM) with $\mathrm{E}_{\max } \% \pm \mathrm{SEM}$ for assays run in triplicate. 
bioRxiv preprint doi: https://doi.org/10.1101/2021.04.22.440994; this version posted May 7, 2021. The copyright holder for this preprint (which was not certified by peer review) is the author/funder, who has granted bioRxiv a license to display the preprint in perpetuity. It is made available under aCC-BY-NC-ND 4.0 International license.

Appendix 1-Table 4. Potency and efficacy table for TRUPATH assay

Potency table (Figure 2G):

\begin{tabular}{|c|c|c|c|c|c|c|c|c|}
\hline Compounds & $\begin{array}{c}\text { Gi1 } \\
\mathrm{EC}_{50} \mathrm{nM} \\
\left(\mathrm{pEC}_{50} \pm\right. \\
\mathrm{SEM})\end{array}$ & $\begin{array}{c}\text { Gi2 } \\
\mathrm{EC}_{50} \mathrm{nM} \\
\left(\mathrm{pEC}_{50} \pm\right. \\
\mathrm{SEM})\end{array}$ & $\begin{array}{c}\text { Gi3 } \\
\mathrm{EC}_{50} \mathrm{nM} \\
\left(\mathrm{pEC} \mathrm{C}_{50} \pm\right. \\
\mathrm{SEM})\end{array}$ & $\begin{array}{c}\text { Goa } \\
\mathrm{EC}_{50} \mathrm{nM} \\
\left(\mathrm{pEC}_{50} \pm\right. \\
\mathrm{SEM})\end{array}$ & $\begin{array}{c}\text { Gob } \\
\mathrm{EC}_{50} \mathrm{nM} \\
\left(\mathrm{pEC} \mathrm{C}_{50} \pm\right. \\
\mathrm{SEM})\end{array}$ & $\begin{array}{c}\mathbf{G z} \\
\mathrm{EC}_{50} \mathrm{nM} \\
\left(\mathrm{pEC}_{50} \pm\right. \\
\mathrm{SEM})\end{array}$ & $\begin{array}{c}\text { 及arr1 } \\
\mathrm{EC}_{50} \mathrm{nM} \\
\left(\mathrm{pEC} C_{50} \pm\right. \\
\mathrm{SEM})\end{array}$ & $\begin{array}{c}\text { 及arr2 } \\
\mathrm{EC}_{50} \mathrm{nM} \\
\left(\mathrm{pEC}_{50} \pm\right. \\
\mathrm{SEM})\end{array}$ \\
\hline DAMGO & $\begin{array}{c}17.39(7.76 \\
\pm 0.08\end{array}$ & $\begin{array}{c}8.53(8.07 \\
\pm 0.05 \\
\end{array}$ & $\begin{array}{c}40.04(7.4 \\
\pm 0.06)\end{array}$ & $\begin{array}{c}6.52(8.19 \\
\pm 0.08) \\
\end{array}$ & $\begin{array}{c}4.38(8.36 \\
\pm 0.07)\end{array}$ & $\begin{array}{c}1.63(8.79 \\
\pm 0.04) \\
\end{array}$ & $\begin{array}{c}321.08(6.49 \\
\pm 0.04) \\
\end{array}$ & $\begin{array}{c}161.07(6.79 \\
\pm 0.05)\end{array}$ \\
\hline SC11 & $\begin{array}{c}1000(5.90 \pm \\
0.13)\end{array}$ & $\begin{array}{c}319.95 \\
(6.49 \pm \\
0.21)\end{array}$ & $\begin{array}{c}790.84 \\
(6.10 \pm \\
0.29\end{array}$ & $\begin{array}{c}247.62 \\
(6.61 \pm \\
0.21)\end{array}$ & $\begin{array}{c}184.07 \\
(6.73 \pm \\
0.16)\end{array}$ & $\begin{array}{c}83.78(7.08 \\
\pm 0.1)\end{array}$ & nd & nd \\
\hline SC12 & $\begin{array}{c}255.75(6.59 \\
\pm 0.14)\end{array}$ & $\begin{array}{c}148.26 \\
(6.83 \pm \\
0.22)\end{array}$ & $\begin{array}{c}1500(5.83 \\
\pm 0.59)\end{array}$ & $\begin{array}{c}64.83(7.19 \\
\pm 0.14)\end{array}$ & $\begin{array}{c}100.91(7 \pm \\
0.13)\end{array}$ & $\begin{array}{c}37.96(7.42 \\
\pm 0.10)\end{array}$ & nd & nd \\
\hline SC13 & $\begin{array}{c}145.27(6.84 \\
\pm 0.07)\end{array}$ & $\begin{array}{c}121.81 \\
(6.91 \pm \\
0.21)\end{array}$ & $\begin{array}{c}255.34 \\
(6.59 \pm \\
0.22)\end{array}$ & $\begin{array}{c}52.94(7.28 \\
\pm 0.14)\end{array}$ & $\begin{array}{c}62.17(7.21 \\
\pm 0.08)\end{array}$ & $\begin{array}{c}14.53(7.84 \\
\pm 0.09)\end{array}$ & nd & nd \\
\hline Buprenorphine & $\begin{array}{c}0.37(9.43 \pm \\
0.18)\end{array}$ & $\begin{array}{c}0.13(9.89 \\
\pm 0.22)\end{array}$ & $\begin{array}{c}0.17(9.77 \\
\pm 0.23)\end{array}$ & $\begin{array}{c}0.17(9.77 \\
\pm 0.1)\end{array}$ & $\begin{array}{c}0.55(9.26 \\
\pm 0.18)\end{array}$ & $\begin{array}{c}0.2(9.7 \pm \\
0.09)\end{array}$ & nd & nd \\
\hline Fentanyl & $\begin{array}{c}12.35(7.91 \\
\pm 0.16)\end{array}$ & $\begin{array}{c}1.15(8.94 \\
\pm 0.17)\end{array}$ & $\begin{array}{c}31.1(7.51 \\
\pm 0.17)\end{array}$ & $\begin{array}{c}3.78(8.42 \\
\pm 0.12)\end{array}$ & $\begin{array}{c}4.08(8.39 \\
\pm 0.08)\end{array}$ & $\begin{array}{c}1.39(8.86 \\
\pm 0.16)\end{array}$ & $\begin{array}{c}300.74(6.52 \\
\pm 0.13)\end{array}$ & $\begin{array}{c}114.29(6.94 \\
\pm 0.11)\end{array}$ \\
\hline Morphine & $\begin{array}{c}51.66(7.29 \\
\pm 0.13\end{array}$ & $\begin{array}{c}18(7.74 \pm \\
0.21)\end{array}$ & $\begin{array}{c}88.27(7.05 \\
\pm 0.16)\end{array}$ & $\begin{array}{c}11.2(7.95 \\
\pm 0.15)\end{array}$ & $\begin{array}{c}15.16(7.82 \\
\pm 0.1)\end{array}$ & $\begin{array}{c}8.22(8.08 \\
\pm 0.18)\end{array}$ & nd & $\begin{array}{c}4930(5.31 \pm \\
00.58)\end{array}$ \\
\hline
\end{tabular}

\section{Efficacy table (Figure 2H):}

\begin{tabular}{|c|c|c|c|c|c|c|c|c|}
\hline Compounds & $\begin{array}{c}\text { Gi1 } \\
\text { Emax\% } \pm \\
\text { SEM }\end{array}$ & $\begin{array}{c}\text { Gi2 } \\
\text { Emax\% } \pm \\
\text { SEM }\end{array}$ & $\begin{array}{c}\text { Gi3 } \\
\text { Emax\% } \pm \\
\text { SEM }\end{array}$ & $\begin{array}{c}\text { Goa } \\
\text { Emax\% } \pm \\
\text { SEM }\end{array}$ & $\begin{array}{c}\text { Gob } \\
\text { Emax\% } \pm \\
\text { SEM }\end{array}$ & $\begin{array}{c}\mathbf{G z} \\
\text { Emax\% } \pm \\
\text { SEM }\end{array}$ & $\begin{array}{c}\text { 及arr1 } \\
\text { Emax\% } \pm \\
\text { SEM }\end{array}$ & $\begin{array}{c}\text { 及arr2 } \\
\text { Emax\% } \pm \\
\text { SEM }\end{array}$ \\
\hline DAMGO & 100 & 100 & 100 & 100 & 100 & 100 & 100 & 100 \\
\hline SC11 & $60.50 \pm 5.01$ & $70.21 \pm 7.05$ & $\begin{array}{c}42.77 \pm \\
7.19\end{array}$ & $\begin{array}{c}64.87 \pm \\
6.28\end{array}$ & $63.87 \pm 4.8$ & $\begin{array}{c}79.47 \pm \\
3.42\end{array}$ & nd & nd \\
\hline SC12 & $61.81 \pm 3.94$ & $74.75 \pm 7.38$ & $\begin{array}{c}32.74 \pm \\
12.54 \\
\end{array}$ & $\begin{array}{c}65.42 \pm \\
3.92 \\
\end{array}$ & $\begin{array}{c}71.24 \pm \\
4.09 \\
\end{array}$ & $81.4 \pm 3.16$ & nd & nd \\
\hline SC13 & $69.66 \pm 2.32$ & $81.45 \pm 7.62$ & $\begin{array}{c}59.78 \pm \\
6.13\end{array}$ & $\begin{array}{c}75.37 \pm \\
4.26\end{array}$ & $\begin{array}{c}73.84 \pm \\
2.58\end{array}$ & $\begin{array}{c}85.66 \pm \\
2.93\end{array}$ & nd & nd \\
\hline Buprenorphine & $43.56 \pm 2.27$ & $59.88 \pm 3.69$ & $\begin{array}{c}40.02 \pm \\
2.63\end{array}$ & $\begin{array}{c}65.49 \pm \\
1.92\end{array}$ & $\begin{array}{c}65.45 \pm \\
3.58\end{array}$ & $\begin{array}{c}80.62 \pm \\
2.14 \\
\end{array}$ & nd & nd \\
\hline Fentanyl & $\begin{array}{c}122.08 \pm \\
8.82\end{array}$ & $94.47 \pm 5.92$ & $\begin{array}{c}111.58 \pm \\
8.99\end{array}$ & $\begin{array}{c}100.36 \pm \\
4.47\end{array}$ & $\begin{array}{c}98.40 \pm \\
2.91\end{array}$ & $\begin{array}{c}93.92 \pm \\
5.69\end{array}$ & $\begin{array}{c}83.24 \pm \\
3.96\end{array}$ & $\begin{array}{c}97.81 \pm \\
4.04\end{array}$ \\
\hline Morphine & $94.89 \pm 4.91$ & $88.54 \pm 7.04$ & $\begin{array}{c}86.34 \pm \\
6.08\end{array}$ & $\begin{array}{c}88.37 \pm \\
4.83\end{array}$ & $\begin{array}{c}94.38 \pm \\
3.38\end{array}$ & $87.7 \pm 5.52$ & nd & $\begin{array}{c}31.68 \pm \\
9.51\end{array}$ \\
\hline
\end{tabular}

Pharmacological parameters from Figure 2G and $\mathbf{2 H}$ for all responding transducers. Potency [EC50 nM (pEC50 \pm SEM)] and efficacy (Emax\% \pm SEM) are reported as estimates from simultaneous curve fitting of all biological replicates and include standard error. nd: $E_{\text {Max }}<10 \%$. 
Appendix 1-Table 5. Compounds and data used to build the statistical models.

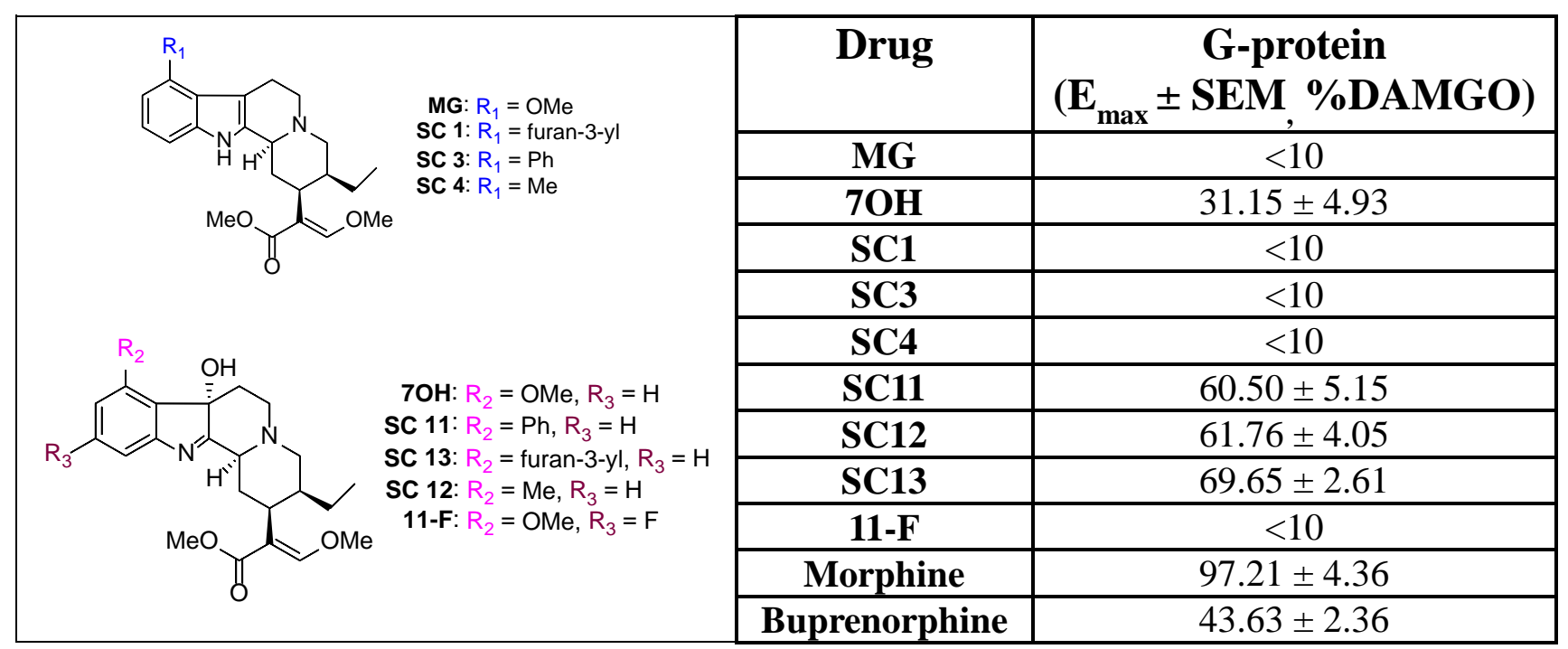


bioRxiv preprint doi: https://doi.org/10.1101/2021.04.22.440994; this version posted May 7, 2021. The copyright holder for this preprint (which was not certified by peer review) is the author/funder, who has granted bioRxiv a license to display the preprint in perpetuity. It is made available under aCC-BY-NC-ND 4.0 International license.

Appendix 1-Table 6. Average Structural Interaction Fingerprints (SIFt) probability for each ligand simulated.

\begin{tabular}{|c|c|c|c|c|c|c|c|c|c|c|c|}
\hline Residue & MG & $70 \mathrm{H}$ & SC1 & SC3 & SC4 & SC11 & SC12 & SC13 & C11-F-7OH & bpr & morphine \\
\hline G efficacy & $10 \%$ & $31 \%$ & $10 \%$ & $10 \%$ & $10 \%$ & $61 \%$ & $62 \%$ & $70 \%$ & $10 \%$ & $43 \%$ & $97 \%$ \\
\hline Y(1.39)_Apolar & - & $34 \%$ & - & - & - & $44 \%$ & - & $41 \%$ & $68 \%$ & - & - \\
\hline Y(1.39)_Aro_E2F & - & $12 \%$ & - & - & - & - & - & $15 \%$ & $30 \%$ & - & - \\
\hline L/M(2.57)_Apolar & - & - & - & - & - & - & - & - & $32 \%$ & - & - \\
\hline Q(2.60)_Apolar & $100 \%$ & $100 \%$ & $100 \%$ & $100 \%$ & $99 \%$ & $100 \%$ & $93 \%$ & $100 \%$ & $97 \%$ & $83 \%$ & - \\
\hline Q(2.60)_Hbond_1Wat & - & - & - & - & - & - & - & - & $14 \%$ & - & - \\
\hline N/V(2.63)_Apolar & $57 \%$ & $71 \%$ & $87 \%$ & $84 \%$ & $72 \%$ & $84 \%$ & $69 \%$ & $79 \%$ & $54 \%$ & $26 \%$ & - \\
\hline Y(2.64)_Apolar & $20 \%$ & $61 \%$ & $15 \%$ & $37 \%$ & - & $38 \%$ & - & $24 \%$ & $55 \%$ & $67 \%$ & $29 \%$ \\
\hline Y(2.64)_Aro_E2F & - & $18 \%$ & - & $24 \%$ & - & $11 \%$ & - & - & $14 \%$ & - & - \\
\hline W(23.50)_Apolar & $93 \%$ & $43 \%$ & $100 \%$ & $93 \%$ & $75 \%$ & $63 \%$ & $46 \%$ & $53 \%$ & $25 \%$ & - & - \\
\hline I/L(3.29)_Apolar & $99 \%$ & $64 \%$ & $100 \%$ & $100 \%$ & $100 \%$ & $78 \%$ & $90 \%$ & $89 \%$ & $37 \%$ & $62 \%$ & - \\
\hline D(3.32)_Apolar & $100 \%$ & $100 \%$ & $100 \%$ & $100 \%$ & $100 \%$ & $100 \%$ & $98 \%$ & $100 \%$ & $99 \%$ & $98 \%$ & $100 \%$ \\
\hline D(3.32)_Elec_ProN & $99 \%$ & $76 \%$ & $97 \%$ & $95 \%$ & $100 \%$ & $87 \%$ & $73 \%$ & $90 \%$ & $54 \%$ & $96 \%$ & $98 \%$ \\
\hline D(3.32)_Hbond_1Wat & - & $27 \%$ & - & - & - & $12 \%$ & $23 \%$ & - & $56 \%$ & $24 \%$ & - \\
\hline D(3.32)_Hbond_ProA & $99 \%$ & $65 \%$ & $96 \%$ & $90 \%$ & $99 \%$ & $70 \%$ & $73 \%$ & $82 \%$ & $35 \%$ & $58 \%$ & $86 \%$ \\
\hline Y(3.33)_Apolar & $100 \%$ & $98 \%$ & $100 \%$ & $100 \%$ & $100 \%$ & $100 \%$ & $99 \%$ & $100 \%$ & $98 \%$ & $100 \%$ & $100 \%$ \\
\hline Y(3.33)_Aro_E2F & - & - & - & - & - & - & - & - & - & $20 \%$ & - \\
\hline Y(3.33)_Hbond_1Wat & $27 \%$ & $25 \%$ & - & - & - & $29 \%$ & $25 \%$ & $30 \%$ & $21 \%$ & $69 \%$ & $56 \%$ \\
\hline Y(3.33)_Hbond_2Wat & $49 \%$ & $55 \%$ & $65 \%$ & $58 \%$ & $58 \%$ & $60 \%$ & $57 \%$ & $62 \%$ & $41 \%$ & $32 \%$ & $44 \%$ \\
\hline M(3.36)_Apolar & $98 \%$ & $98 \%$ & $99 \%$ & $100 \%$ & $98 \%$ & $99 \%$ & $99 \%$ & $97 \%$ & $95 \%$ & $92 \%$ & $99 \%$ \\
\hline F(3.37)_Apolar & - & $12 \%$ & - & - & - & - & - & $26 \%$ & - & - & - \\
\hline C(45.50)_Apolar & $85 \%$ & $47 \%$ & $97 \%$ & $97 \%$ & $62 \%$ & $81 \%$ & $76 \%$ & $77 \%$ & $24 \%$ & $23 \%$ & - \\
\hline C(45.50)_Hbond_1Wat & $20 \%$ & $34 \%$ & - & - & - & - & $25 \%$ & $12 \%$ & $14 \%$ & - & - \\
\hline C(45.50)_Hbond_2Wat & - & $28 \%$ & - & - & - & $13 \%$ & $18 \%$ & $23 \%$ & $23 \%$ & $24 \%$ & - \\
\hline T/S(45.51)_Apolar & - & - & - & - & - & - & $17 \%$ & - & - & - & - \\
\hline L(45.52)_Hbond_2Wat & - & $13 \%$ & - & - & - & - & $19 \%$ & - & - & $17 \%$ & - \\
\hline E(5.35)_Hbond_2Wat & - & - & - & - & - & - & - & - & - & $20 \%$ & $15 \%$ \\
\hline K(5.39)_Hbond_2Wat & $33 \%$ & $15 \%$ & $27 \%$ & $25 \%$ & $34 \%$ & $14 \%$ & $11 \%$ & $11 \%$ & $11 \%$ & $11 \%$ & $22 \%$ \\
\hline V(5.42)_Apolar & $56 \%$ & $72 \%$ & $46 \%$ & $59 \%$ & $52 \%$ & $78 \%$ & $78 \%$ & $83 \%$ & $77 \%$ & $99 \%$ & $88 \%$ \\
\hline A(5.46)_Apolar & - & - & - & - & - & - & - & $14 \%$ & $10 \%$ & - & - \\
\hline W(6.48)_Apolar & $80 \%$ & $97 \%$ & $90 \%$ & $87 \%$ & $76 \%$ & $99 \%$ & $90 \%$ & $100 \%$ & $92 \%$ & $85 \%$ & $41 \%$ \\
\hline I(6.51)_Apolar & $97 \%$ & $99 \%$ & $97 \%$ & $98 \%$ & $98 \%$ & $99 \%$ & $100 \%$ & $93 \%$ & $97 \%$ & $98 \%$ & $95 \%$ \\
\hline H(6.52)_Apolar & $99 \%$ & $96 \%$ & $100 \%$ & $99 \%$ & $95 \%$ & $99 \%$ & $92 \%$ & $95 \%$ & $91 \%$ & $95 \%$ & $91 \%$ \\
\hline H(6.52)_Aro_E2F & - & - & - & - & - & - & - & - & - & $84 \%$ & $77 \%$ \\
\hline V/I(6.55)_Apolar & $70 \%$ & $38 \%$ & $62 \%$ & $48 \%$ & $55 \%$ & $55 \%$ & $66 \%$ & $47 \%$ & $35 \%$ & $89 \%$ & $55 \%$ \\
\hline W/Y(7.35)_Apolar & - & $14 \%$ & - & - & - & $11 \%$ & $39 \%$ & $16 \%$ & - & $99 \%$ & $73 \%$ \\
\hline W/Y(7.35)_Hbond_1Wat & - & $30 \%$ & - & - & - & $27 \%$ & $23 \%$ & $21 \%$ & $47 \%$ & - & - \\
\hline W/Y(7.35)_Hbond_2Wat & $18 \%$ & $28 \%$ & $26 \%$ & $33 \%$ & $27 \%$ & $32 \%$ & $27 \%$ & $38 \%$ & $23 \%$ & - & $27 \%$ \\
\hline W/Y(7.35)_Hbond_ProD & - & - & - & - & - & - & - & - & - & - & - \\
\hline H/Y(7.36)_Apolar & - & $57 \%$ & - & $10 \%$ & - & $86 \%$ & $28 \%$ & $82 \%$ & $75 \%$ & - & - \\
\hline H/Y(7.36)_Aro_E2F & - & $36 \%$ & - & - & - & $56 \%$ & $13 \%$ & $49 \%$ & $44 \%$ & - & - \\
\hline H/Y(7.36)_Hbond_2Wat & - & $12 \%$ & - & - & - & $10 \%$ & - & - & $14 \%$ & - & - \\
\hline I(7.39)_Apolar & $69 \%$ & $99 \%$ & $92 \%$ & $96 \%$ & $84 \%$ & $99 \%$ & $98 \%$ & $99 \%$ & $100 \%$ & $92 \%$ & $98 \%$ \\
\hline G(7.42)_Apolar & $47 \%$ & $94 \%$ & $75 \%$ & $79 \%$ & $61 \%$ & $92 \%$ & $64 \%$ & $91 \%$ & $96 \%$ & $95 \%$ & - \\
\hline Y(7.43)_Apolar & $58 \%$ & $96 \%$ & $83 \%$ & $100 \%$ & $74 \%$ & $98 \%$ & $98 \%$ & $99 \%$ & $95 \%$ & $100 \%$ & $86 \%$ \\
\hline Y(7.43)_Hbond_1Wat & - & $10 \%$ & - & - & - & - & - & - & $27 \%$ & $22 \%$ & - \\
\hline Q(2.60)_Hbond_2Wat & $18 \%$ & - & $29 \%$ & $23 \%$ & $31 \%$ & - & - & - & - & - & - \\
\hline S(2.61)_Apolar & - & - & - & - & - & $20 \%$ & - & $31 \%$ & $31 \%$ & - & - \\
\hline V(3.28)_Apolar & $89 \%$ & - & $99 \%$ & $98 \%$ & $76 \%$ & $22 \%$ & $17 \%$ & $37 \%$ & - & - & - \\
\hline T/S(45.51)_Hbond_2Wat & - & $14 \%$ & - & - & - & - & $18 \%$ & - & - & $24 \%$ & - \\
\hline Y(1.39)_Aro_F2F & - & - & - & - & - & - & - & - & $13 \%$ & - & - \\
\hline H(6.52)_Hbond_1Wat & - & - & - & - & - & - & - & - & $10 \%$ & - & - \\
\hline Y(1.39)_Hbond_2Wat & $12 \%$ & - & $20 \%$ & $15 \%$ & $21 \%$ & - & - & - & - & - & - \\
\hline Q(2.60)_Hbond_ProD & $22 \%$ & - & - & - & - & - & - & - & - & - & - \\
\hline K(5.39)_Apolar & $21 \%$ & - & - & - & - & - & - & - & - & $35 \%$ & - \\
\hline F(5.43)_Apolar & $13 \%$ & - & - & - & - & - & - & - & - & - & - \\
\hline H(6.52)_Hbond_2Wat & $21 \%$ & $11 \%$ & $21 \%$ & $17 \%$ & $28 \%$ & - & - & - & - & - & - \\
\hline N/V(2.63)_Hbond_2Wat & - & $13 \%$ & - & - & - & - & - & - & - & - & - \\
\hline W(23.50)_Aro_E2F & - & - & $31 \%$ & $18 \%$ & $19 \%$ & $34 \%$ & - & $31 \%$ & - & - & - \\
\hline W(23.50)_Aro_F2F & - & - & $70 \%$ & $69 \%$ & - & $12 \%$ & - & $13 \%$ & - & - & - \\
\hline C(3.25)_Apolar & - & - & $37 \%$ & $15 \%$ & - & - & - & - & - & - & - \\
\hline L/M(5.38)_Hbond_2Wat & - & - & $11 \%$ & - & - & - & - & - & - & - & - \\
\hline I/L(3.29)_Hbond_1Wat & - & - & - & - & - & - & $17 \%$ & - & - & - & - \\
\hline L(45.52)_Apolar & - & - & - & - & - & - & $18 \%$ & - & - & - & - \\
\hline F(2.59)_Apolar & - & - & - & $40 \%$ & - & - & - & - & - & - & - \\
\hline Y(2.64)_Hbond_2Wat & - & - & - & $10 \%$ & - & - & - & - & - & - & $10 \%$ \\
\hline W/Y(7.35)_Aro_E2F & - & - & - & - & - & - & - & - & - & - & - \\
\hline
\end{tabular}


bioRxiv preprint doi: https://doi.org/10.1101/2021.04.22.440994; this version posted May 7, 2021. The copyright holder for this preprint (which

was not certified by peer review) is the author/funder, who has granted bioRxiv a license to display the preprint in perpetuity. It is made available under aCC-BY-NC-ND 4.0 International license.

\begin{tabular}{|ccccccccccc|}
\hline Y(2.64)_Aro_F2F & - & - & - & - & - & - & - & - & - & - \\
\hline Y(2.64)_Hbond_1Wat & - & - & - & - & - & - & - & - & - & - \\
\hline
\end{tabular}

Appendix 1-Table 7. Interactions in the top statistical models that are predicted to either enhance (negative coefficients) or reduce (positive coefficients) ligand-induced MOR activation and consequent G protein signaling.

\begin{tabular}{|c|c|c|c|c|c|c|c|c|}
\hline \multirow[b]{2}{*}{ Residue } & \multirow[b]{2}{*}{ Interaction } & \multirow[b]{2}{*}{ Avg. Coeff } & \multicolumn{2}{|c|}{ Morphine } & \multicolumn{2}{|c|}{ SC11-13 } & \multicolumn{2}{|c|}{ Buprenorphine } \\
\hline & & & Prob. & Effect & Prob. & Effect. & Prob. & Effect \\
\hline \multicolumn{9}{|c|}{ Interactions reducing $\mathrm{G}$ protein signaling } \\
\hline $\mathrm{Y}(1.39)$ & Apolar & 7.46 & - & & $28 \%$ & $\downarrow \downarrow$ & - & \\
\hline $\mathrm{V}(2.63)$ & Apolar & 2.81 & - & & $77 \%$ & $\downarrow \downarrow$ & $26 \%$ & $\downarrow$ \\
\hline$C(45.50)$ & Apolar & 2.43 & - & & $78 \%$ & $\downarrow \downarrow$ & $23 \%$ & $\downarrow$ \\
\hline $\mathrm{L}(3.29)$ & Apolar & 2.30 & - & & $86 \%$ & $\downarrow \downarrow$ & $62 \%$ & $\downarrow \downarrow$ \\
\hline $\mathrm{W}(23.50)$ & Apolar & 1.99 & - & & $54 \%$ & $\downarrow \downarrow$ & - & \\
\hline \multicolumn{9}{|c|}{ Interactions enhancing $G$ protein signaling } \\
\hline $\mathrm{H}(6.52)$ & Aro_E2F & -2.32 & $77 \%$ & $\uparrow \uparrow$ & - & & $84 \%$ & $\uparrow \uparrow$ \\
\hline $\mathrm{Y}(7.36)$ & Apolar & -5.76 & - & & $65 \%$ & $\uparrow \uparrow$ & - & \\
\hline $\mathrm{Y}(7.36)$ & Aro_E2F & -8.65 & - & & $39 \%$ & $\uparrow \uparrow$ & - & \\
\hline
\end{tabular}


Appendix 1-Table 8. Selected models for the prediction of the negative log of the efficacy $-\log \left(E_{\operatorname{Max}}\right)$ as a function of interaction probabilities. The $\mathrm{R}^{2}$ on the full training set and the LOO-RMSE are reported for each model, as well as the values of the coefficient estimates and their standard errors.

\begin{tabular}{|c|c|c|c|c|c|}
\hline Model ID & $\mathbf{R}^{2}$ & LOO-RMSE & Interaction & Coefficient & std. Error \\
\hline \multirow[t]{4}{*}{1} & 0.936 & 0.312 & (intercept) & 0.176 & 0.244 \\
\hline & & & Y(1.39)_Apolar & 7.633 & 1.083 \\
\hline & & & N/V(2.63)_Apolar & 2.954 & 0.41 \\
\hline & & & H/Y(7.36)_Apolar & -6.353 & 0.756 \\
\hline \multirow[t]{4}{*}{2} & 0.93 & 0.494 & (intercept) & 0.513 & 0.218 \\
\hline & & & H/Y(7.36)_Aro_E2F & -7.572 & 1.151 \\
\hline & & & Y(1.39)_Apolar & 6.749 & 1.068 \\
\hline & & & W(23.50)_Apolar & 1.973 & 0.317 \\
\hline \multirow[t]{4}{*}{3} & 0.918 & 0.531 & (intercept) & 0.335 & 0.279 \\
\hline & & & Y(1.39)_Apolar & 9.097 & 1.466 \\
\hline & & & C(45.50)_Apolar & 2.428 & 0.424 \\
\hline & & & H/Y(7.36)_Apolar & -6.558 & 0.99 \\
\hline \multirow[t]{4}{*}{4} & 0.916 & 0.366 & (intercept) & 0.19 & 0.279 \\
\hline & & & H/Y(7.36)_Aro_E2F & -9.397 & 1.349 \\
\hline & & & Y(1.39)_Apolar & 7.077 & 1.217 \\
\hline & & & N/V(2.63)_Apolar & 2.659 & 0.463 \\
\hline \multirow[t]{4}{*}{5} & 0.907 & 0.386 & (intercept) & -0.06 & 0.361 \\
\hline & & & Y(1.39)_Apolar & 8.523 & 1.468 \\
\hline & & & I/L(3.29)_Apolar & 2.394 & 0.441 \\
\hline & & & H/Y(7.36)_Apolar & -5.918 & 0.955 \\
\hline \multirow[t]{4}{*}{6} & 0.904 & 0.484 & (intercept) & -0.068 & 0.348 \\
\hline & & & H/Y(7.36)_Aro_E2F & -8.988 & 1.395 \\
\hline & & & Y(1.39)_Apolar & 8.093 & 1.337 \\
\hline & & & I/L(3.29)_Apolar & 2.211 & 0.408 \\
\hline \multirow[t]{4}{*}{7} & 0.901 & 0.624 & (intercept) & 0.583 & 0.274 \\
\hline & & & Y(1.39)_Apolar & 6.629 & 1.363 \\
\hline & & & W(23.50)_Apolar & 2.014 & 0.38 \\
\hline & & & H/Y(7.36)_Apolar & -4.657 & 0.915 \\
\hline \multirow[t]{4}{*}{8} & 0.899 & 0.403 & (intercept) & 2.327 & 0.195 \\
\hline & & & Y(1.39)_Apolar & 5.867 & 1.255 \\
\hline & & & H(6.52)_Aro_E2F & -2.321 & 0.41 \\
\hline & & & H/Y(7.36)_Apolar & -5.324 & 0.872 \\
\hline
\end{tabular}




\section{Appendix 1-Figure 1. Characterization of SC11-13 in cAMP, Tango arrestin, PathHunter arrestin, binding, Nb33 recruitment at h/mMOR and Gi-signaling at hKOR and hDOR.}

A) SC11-13 are full agonists at hMOR in cAMP inhibition $(\mathrm{N}=3)$ compared to DAMGO. See table 1 (main paper) for values B) SC11-13 showed robust arrestin recruitment $\left(E_{\max }>100 \%\right.$ for SC11-12 \&45\% for SC13) with poor potency $\left(\mathrm{EC}_{50}>10 \mu \mathrm{M}\right)$ in Tango assays at MOR. See table $\mathbf{1}$ (main paper) for values. C) SC11-13 in PathHunterarrestin recruitment assays $(\mathrm{n}=3)$ show less $\beta$ arrestin-2 recruitment compared to DAMGO. $\boldsymbol{\beta}$-arrestin2: SC11 EC50 $\mathrm{nM}(\mathrm{pEC} 50 \pm \mathrm{SEM})=$ n.d., $\mathrm{E}_{\max } \% \pm \mathrm{SEM}=<20 \%$, $\boldsymbol{\beta}$-arrestin2: 2 SC12 $\mathrm{EC}_{50} \mathrm{nM}(\mathrm{pEC} 5 \pm \pm \mathrm{SEM})=$ n.d., $\mathrm{E}_{\max } \% \pm$ $\mathrm{SEM}=<20 \%$, $\boldsymbol{\beta}$-arrestin2: SC13 $\mathrm{EC}_{50} \mathrm{nM}\left(\mathrm{pEC}_{50} \pm \mathrm{SEM}\right)=$ n.d., $\mathrm{E}_{\max } \% \pm \mathrm{SEM}=<20 \%$, $\boldsymbol{\beta}$-arrestin2: morphine $\mathrm{EC}_{50} \mathrm{nM}\left(\mathrm{pEC}_{50} \pm \mathrm{SEM}\right)=80.08(7.09 \pm 0.17) \mathrm{nM}, \mathrm{E}_{\max } \% \pm \mathrm{SEM}=33.08 \pm 1.84, \boldsymbol{\beta}$-arrestin2: DAMGO EC $50 \mathrm{nM}$ $\left(\mathrm{pEC}_{50} \pm \mathrm{SEM}\right)=281.57(6.55 \pm 0.2) \mathrm{nM}$. D) In competitive radioligand binding assays in MOR-CHO using ${ }^{3} \mathrm{H}-$ DAMGO as radioligand, SC11-13 labelled MOR with high to reasonable affinity. SC13 $\mathrm{K}_{\mathrm{i}}\left(\mathrm{pK} \mathrm{K}_{\mathrm{i}} \pm \mathrm{SEM}\right)=6.05(8.22$ $\pm 0.08)$, SC12 $\mathrm{K}_{\mathrm{i}}(\mathrm{pK} \mathrm{i} \pm \mathrm{SEM})=12.33(7.91 \pm 0.03), \mathrm{SC1}_{\mathrm{i}}\left(\mathrm{pK}_{\mathrm{i}} \pm \mathrm{SEM}\right)=15.42(7.81 \pm 0.06)$, morphine $\mathrm{K}_{\mathrm{i}}\left(\mathrm{pK}_{\mathrm{i}}\right.$ $\pm \mathrm{SEM})=0.37(9.42 \pm 0.04)$, DAMGO $\mathrm{K}_{\mathrm{i}}\left(\mathrm{pK}_{\mathrm{i}} \pm \mathrm{SEM}\right)=0.49(9.31 \pm 0.03)$. E) Gi-1 activation in BRET assays of controls. Fentanyl had higher efficacy over DAMGO. Efficacy of morphine was 94\% and buprenorphine showed 44\% efficacy. See appendix 1-table 3 for values. F) $\beta$-arrestin2 recruitment in BRET assays of controls. Fentanyl showed robust arrestin recruitment with efficacy of 94\%, morphine showed 31\% efficacy while buprenorphine showed no recruitment. See appendix 1-table 3 for values. G) No measurable Gi-1 potency was observed for SC13 at hKOR. U50488 EC $50 \mathrm{nM}\left(\mathrm{pEC}_{50} \pm \mathrm{SEM}\right)=8.07(8.09 \pm 0.27) \mathrm{nM}$. SC13 EC $50 \mathrm{nM}(\mathrm{pEC} 50 \pm \mathrm{SEM})=$ n.d., $\mathrm{E}_{\max } \%$ $\pm \mathrm{SEM}=38 \pm 17$. H) No measurable Gi-1 potency was observed for SC13 at hDOR. SC 13 EC $50 \mathrm{nM}(\mathrm{pEC} 50 \pm \mathrm{SEM})$ $=$ n.d; $E_{\max } \% \pm S E M=88 \pm 35$ at hDOR. I) Efficacy of SC compounds, buprenorphine and morphine at the human opioid receptors in BRET-based Nb33 recruitment assaysare shown as a percentage of receptor activation relative to the full agonist, DAMGO. SC11-13 had significantly lower efficacy than DAMGO $(\mathrm{p}<0.0001)$ and morphine $(\mathrm{p}<0.0001)$ and similar efficacy to buprenorphine. Statistical significance was determined using one-way ANOVA followed by Dunnett's multiple comparison test, $F(5,68)=239.172 .5, p<0.0001$. J) Efficacy of SC compounds, buprenorphine and morphine at the mouse opioid receptors in BRET-based Nb33 recruitment assays are shown as a percentage of receptor activation relative to the full agonist, DAMGO. SC11-13 had significantly lower efficacy than DAMGO ( $<<0.0001)$, morphine $(\mathrm{p}<0.0001)$, and similar efficacy to buprenorphine. Statistical significance was determined using one-way ANOVA followed by Dunnett's multiple comparison test, $F(5,64)=572.5, \mathrm{p}<0.0001$. 


\section{Appendix 1-Figure 2. Binding modes and interactions of SC11-13 compared to morphine.}

(A-C) Representative conformations of the most populated clusters from MD simulations of MOR bound to SC11 (blue), SC12 (teal), and SC13 (purple) (panels A-C, respectively), compared to a representative conformation of MOR bound to morphine (orange). The protein is represented as a gray cartoon in the morphine-MOR complex. Residues identified in the best 8 performing models on experimental data are indicated with sticks. Transmembrane helices 5 and 6 are not shown for clarity. (D) Differences (plot at the bottom) between average structural interaction fingerprints (SIFts) calculated for SC11-13 (plot in the middle) and SIFts calculated for morphine (plot at the top).

Appendix 1-Figure 3. Full training set $\mathrm{R}^{2}$ validation and leave-one-out (LOO) cross-validation root mean square error (RMSE) for models with $\mathrm{R}^{2}>0.75$. Models with $\mathrm{R}^{2}$ in the top quartile (red points) were selected as best performing models on experimental data.

Appendix 1-Figure 4. Values of the negative logarithm of the $G$ protein efficacy $E_{\max }$ predicted from the selected top 25\% models, compared to the experimental values for morphine (red), the SC11-13 ligands (blue), buprenorphine (green), and the remaining 6 ligands in the training set (purple). 
A

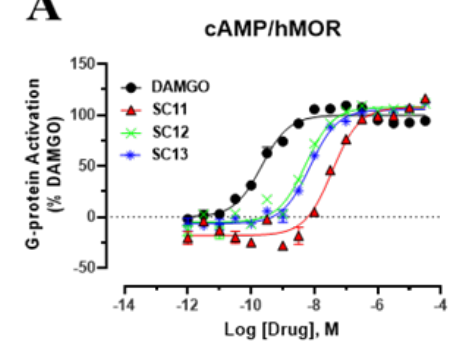

D
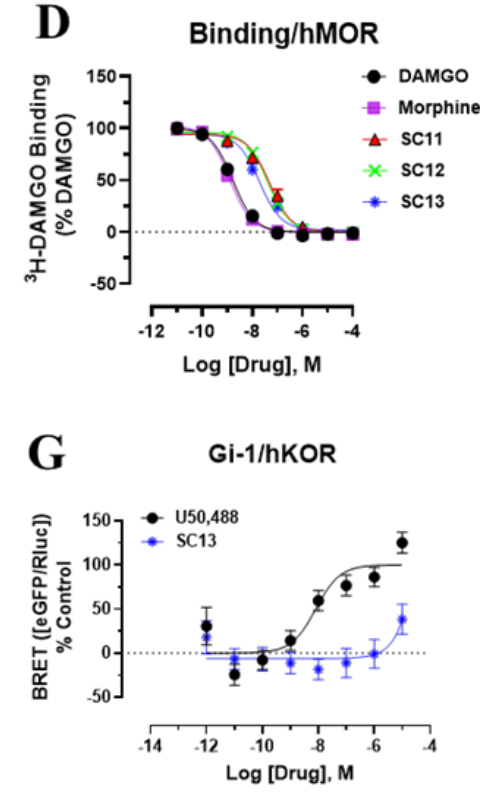

Log [Drug], M
B

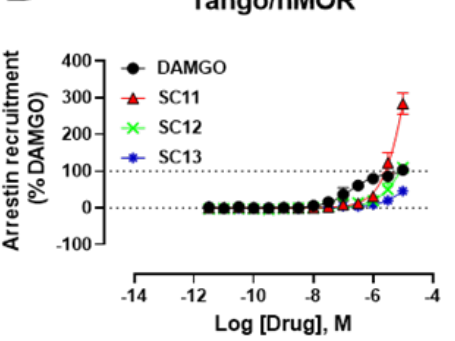

E

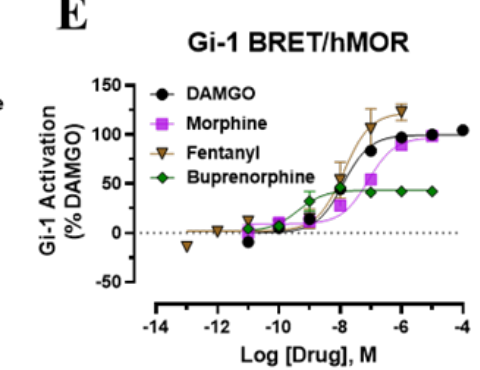

H

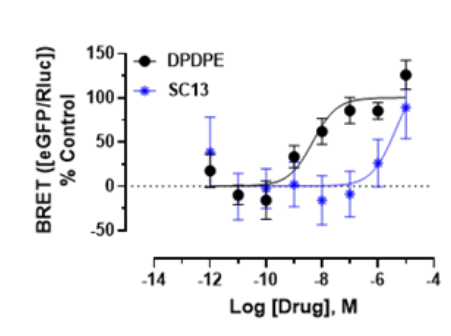

$\mathbf{J}$
C Pathhunter/hMOR

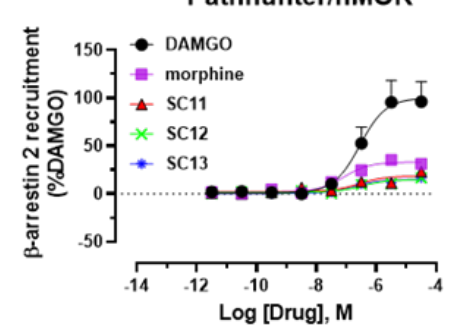

F

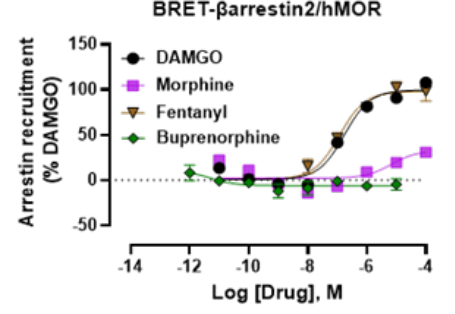

I efficacy-hLuc

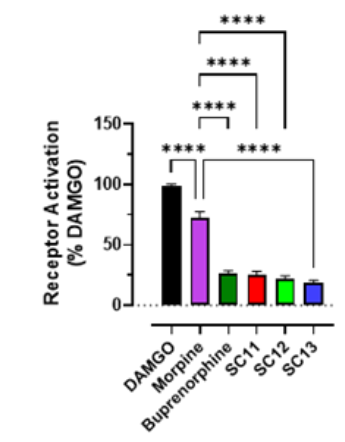

Appendix1-Figure1

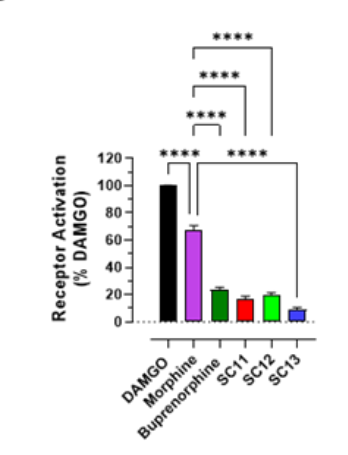



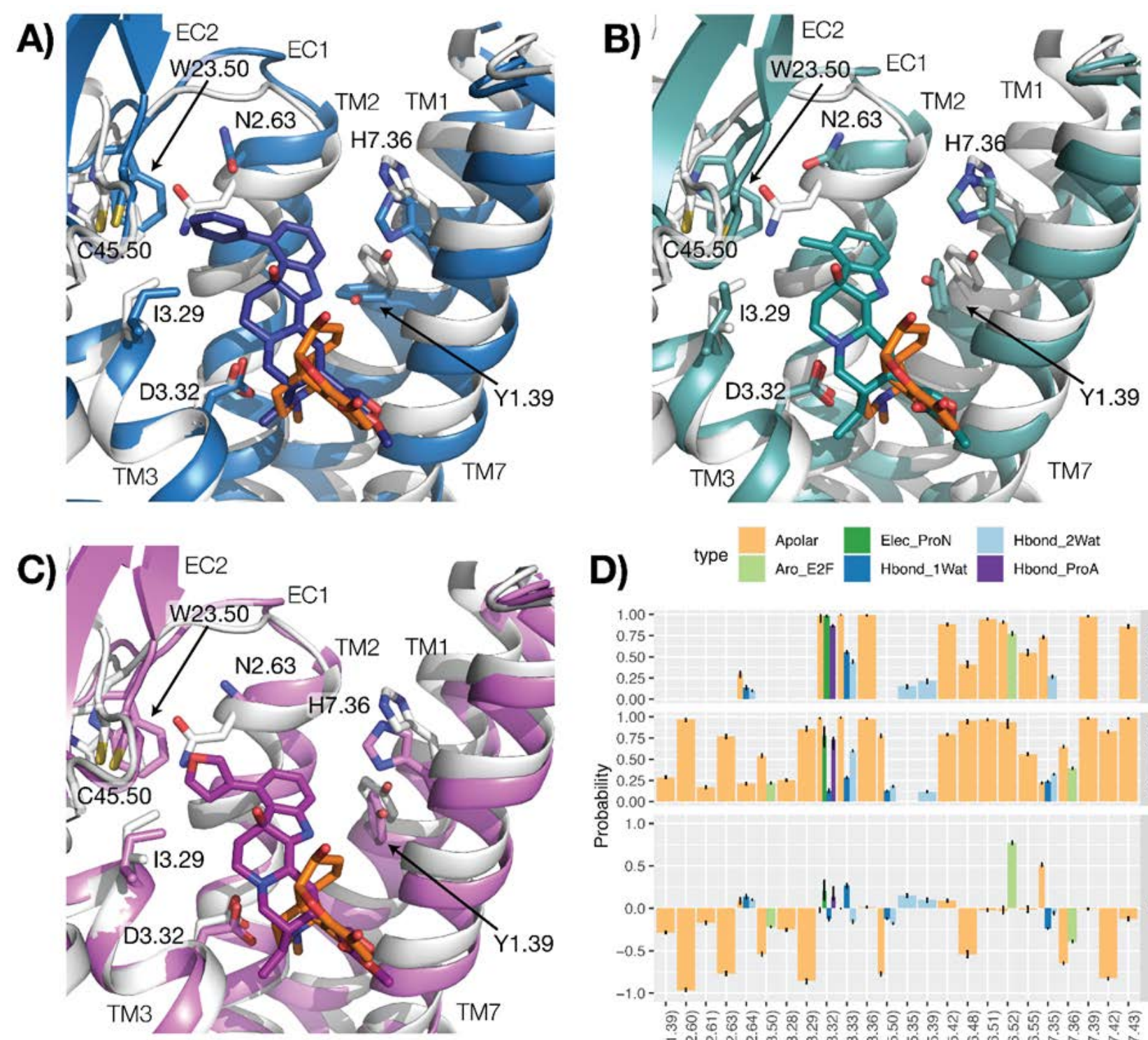

D) type ${ }_{\text {Apolar }}^{\text {Ap2F }} \square$ Hbond_1Wat $\square$ Hbond_ProA

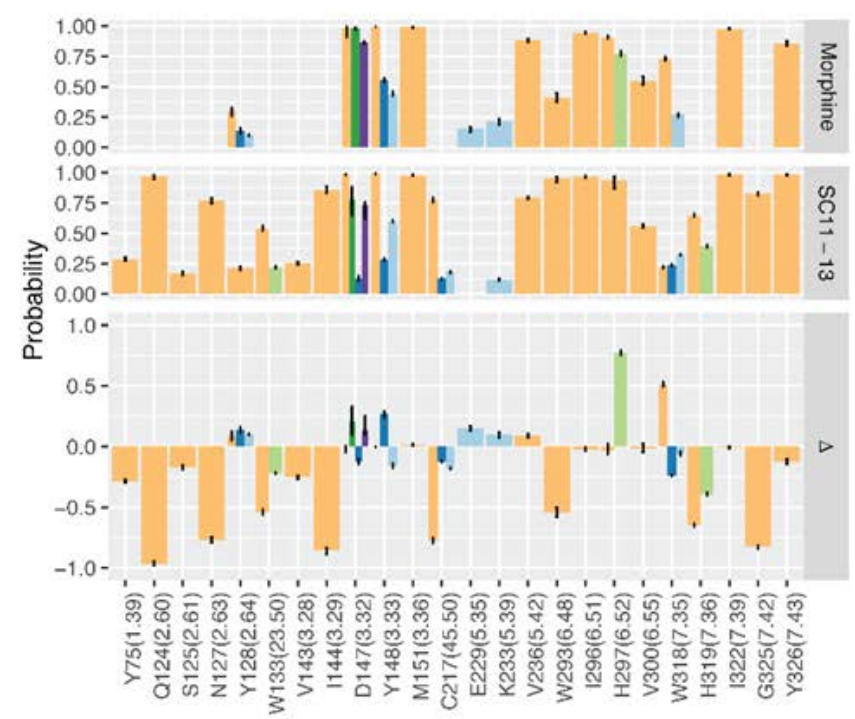

\section{Appendix1-Figure2}




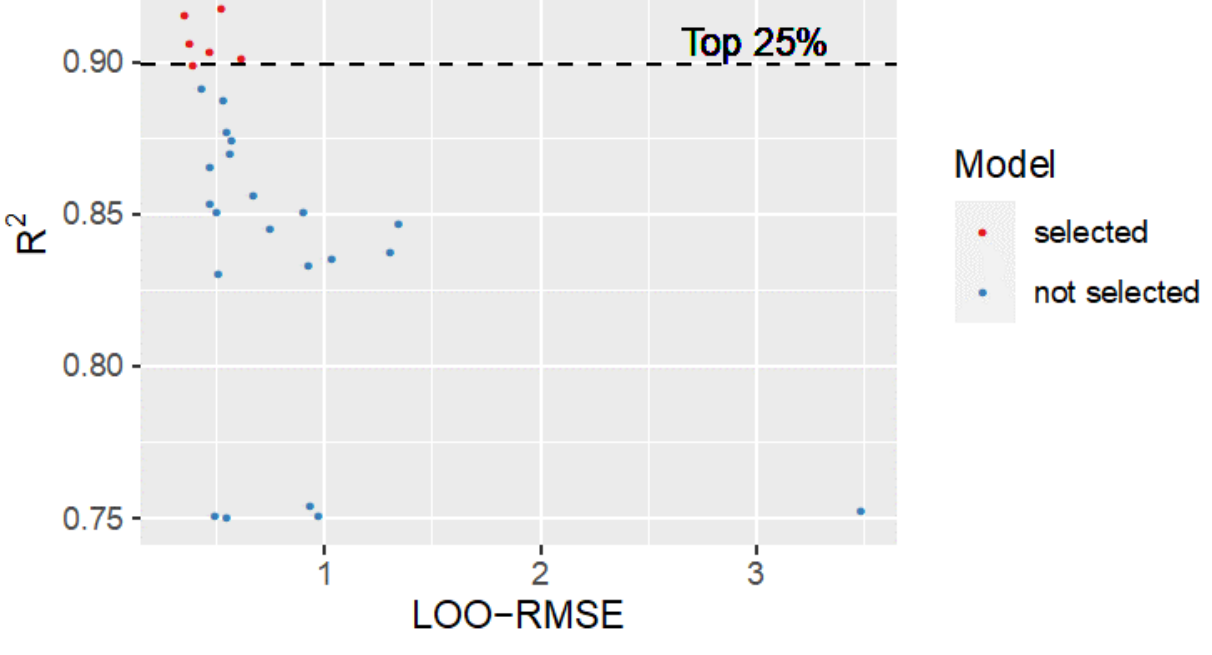

Appendix1-Figure3 


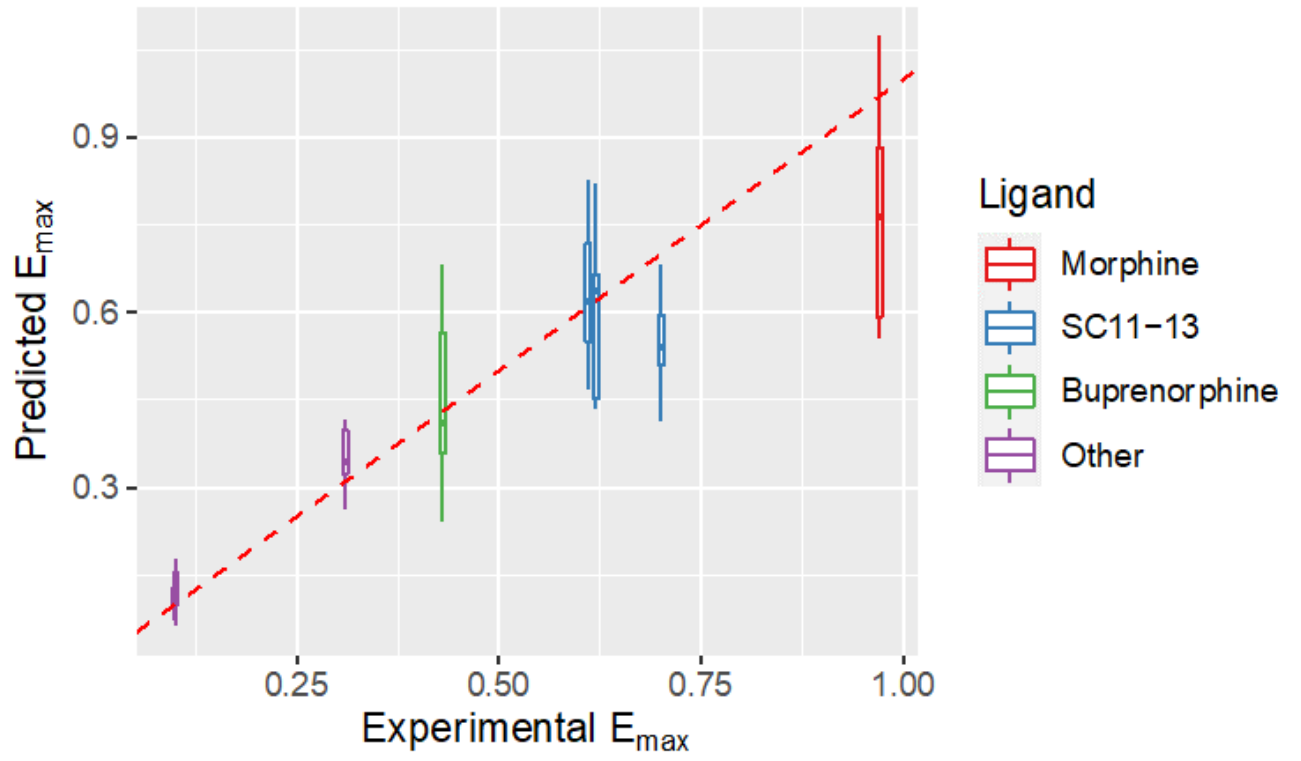

Appendix1-Figure4 